Portland State University

PDXScholar

1985

\title{
A social-psychological case history : the Manson incident
}

Judith Elaine Bullis

Portland State University

Follow this and additional works at: https://pdxscholar.library.pdx.edu/open_access_etds

Part of the Criminology Commons, and the Social Psychology Commons Let us know how access to this document benefits you.

\section{Recommended Citation}

Bullis, Judith Elaine, "A social-psychological case history : the Manson incident" (1985). Dissertations and Theses. Paper 3564.

https://doi.org/10.15760/etd.5446

This Thesis is brought to you for free and open access. It has been accepted for inclusion in Dissertations and Theses by an authorized administrator of PDXScholar. Please contact us if we can make this document more accessible: pdxscholar@pdx.edu. 
AN ABSTRACT OF THE THESIS OF Judith ETaine Bullis for the Master of Science in Psychology presented December 20, 1985.

Title: A Social-Psychological Case History: The Manson Incident

APPROVED BY MEMBERS OF THE THESIS COMMITTEE:

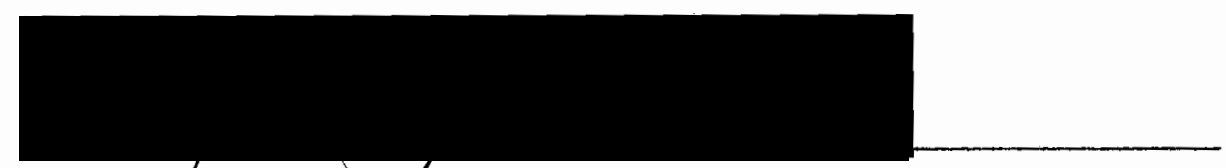

Hugo Thanard; Thairman

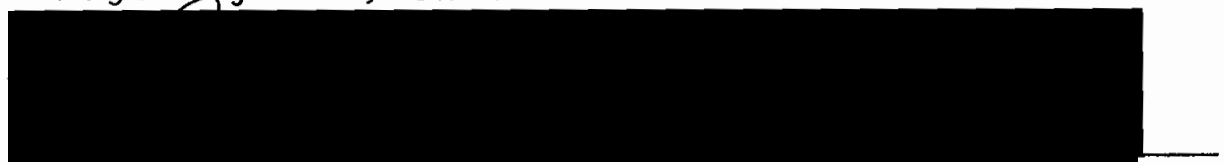

David L. Cressler

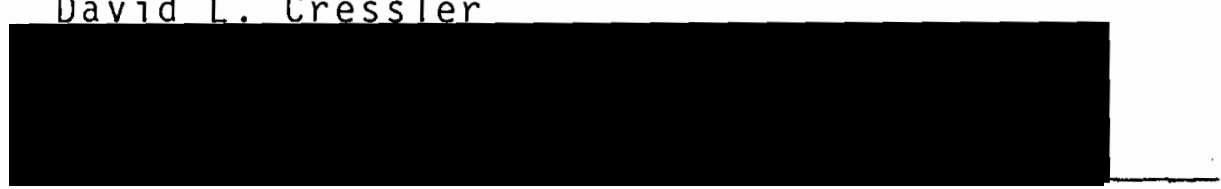

Robert W. Lockwood

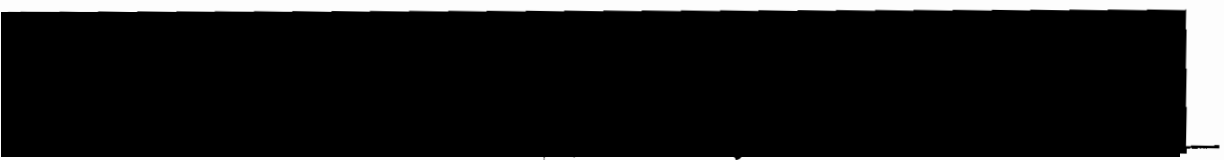

Steven A. Kosokoff

This study examines the social-psychological impact of of the Manson incident; which begins with the Tate-Labianca murders, continues with the arrest of charles Manson and some of his followers, continues with the trial of Charles Manson and the co-defendants, and results in a popular image .

The media image of this event, which is the base for 
the popular image, was assessed. A content analysis of the coverage of the Manson case was done. Magazine articles cited in Reader's Guide, and articles in The New York Times from August 9, 1969 through 1984 were examined. It was found that the media image most closely resembled the image of the case presented by the chief prosecutor, Vincent Bugliosi, which became known as helter skelter.

The familiarity of this case was determined. It was found that most people are familiar with the Manson case. Further, it was found that this is unusual. Subjects were unable to identify comparable cases to any substantial degree.

The murder cases which were compared to the Manson case were chosen because they had a salient aspect in common with the Manson case: a famous victim, a pregnant victim, random selection of victims, mutilation, a large number of victims, a message left at the scene, repeated multiple murder, domination resulting in murder, a leader who has others kill for him, women murderers, an ideological motive, and undersirables killing socially acceptable people. None of these conditions, in and of themselves, produced a consistant difference in how subjects reported that they felt about a case. None of these aspects seems to be the key to the notoriety of the Manson case.

The popular image of the Manson case was determined by means of a content analysis of essay-type responses to 
the question, what do you know about charles Manson? It was found that the popular image of the case resembles the media image, but that many of the facts were deleted in the process of the formation of the popular image. A point in fact is that few subjects knew the identity of any of the co-defendants, even though they were responsible for the actual killing. A process much like that of rumor formation, as described by Allport, has occurred.

The Manson incident is a kind of cultural volcano. It was intense and produced a lasting effect on the imagery of crime and violence. It was widely regarded as having a powerful cultural effect by contributing to the end of one of the decades of cultural experiment and change in this century. 
A SOCIAL-PSYCHOLOGICAL CASE HISTORY:

THE MANSON INCIDENT.

by

Judith Elaine Bullis

thes is submitted in partial fulfillment of the requirements for the degree of

MASTER OF SCIENCE
in
PSYCHOLOGY

Portland State University

1985 
TO THE OFFICE OF GRADUATE STUDIES AND RESEARCH:

The members of the Committee approve the thesis of Judith Elaine Bullis presented December 20, 1985.

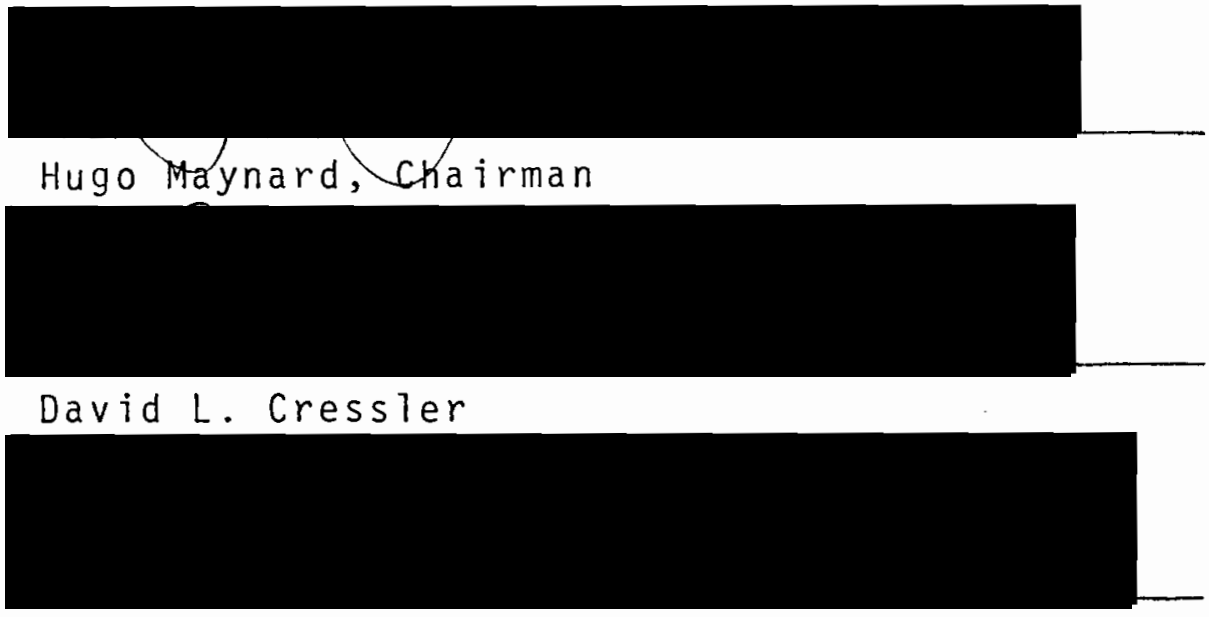

Robert W. Lockwood

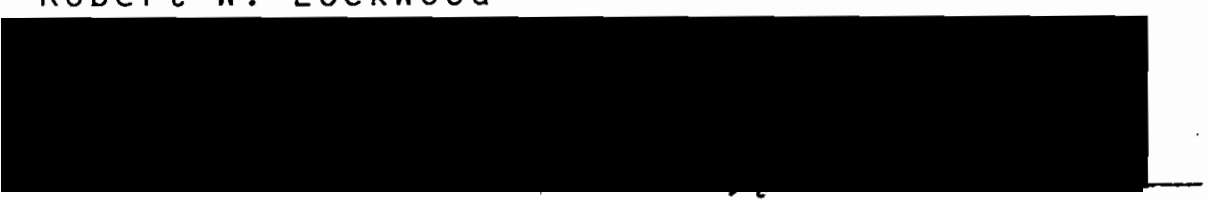

Steven A. Kosokoff

APPROVED :

Rogery D. Jennings, Head, Depa/tment of Psychology

Jim F Heath, Dean, Graduate Studies and Research 


\section{ACKNOWLEDGEMENTS}

This area of study is often emotionally draining, and may not be possible without a co-conspirator. My most sincere thanks go to Hugo Maynard, who most admirably filled this role. His continued support, enthusiasm, insight and outside agitation were vital to the completion of this project.

I would like to express my appreciation to the other members of my committee for their patience, expertise and willingness to deal with my chosen subject matter.

A special thanks to Dr. Kathy Chambers for a good working knowledge of experimental design and methodology. It held me in good stead.

From the beginning of this project Maud hager has acted as an advisor, patron, friend, sounding-board and mother. For this unusual degree of support I am very grateful. 


\section{DEDICATION}

This document is respectfully dedicated to the victims, both living and dead, of the accounts that lie within. 
TABLE OF CONTENTS

PAGE

ACKNOWLEDGEMENTS . . . . . . . . . . . . . . . . . . .

DEDICATION . . . . . . . . . . . . . . . . . . iv LIST OF TABLES....................... . . . . . . . . . . . . . . . .

CHAPTER

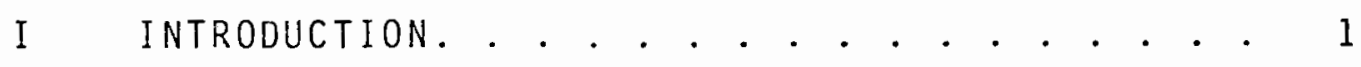

i I ReView of the Literature. . . . . . . . . . 25

The Manson Case. . . . . . . . . 25

Mass Murder............ . . 36

Comparable Cases............ 43

II I METHOD. . . . . . . . . . . . . . 50

Subjects and Selection Criteria... . 50

The Manson Survey. . . . . . . . . . 51

The Mass Murder Survey . . . . . . . 53

The Comparable Cases... . . . . . 55

The Recognition Poll. . . . . . . . 57

The Media Coverage . . . . . . . . 58

Procedure............... . . 59

IV RESULTS................. . 61

The Manson Survey. . . . . . . . . 63

The Mass Murder Survey . . . . . . . . 71 
The Recognition Poll........ 84

The Comparable Cases... . . . . . 85

The Media Coverage . . . . . . . . . 96

Inter-Rater Reliability. . . . . . . . 101

$\checkmark$ DISCUSSION................ 102

BIBLIOGRAPHIES . . . . . . . . . . . . . 120

A General REFERENCES. . . . . . . . . . . 120

B MAGAZINE ARTICLES............... 124

C NEW YORK TIMES ARTICLES . . . . . . . . . 128

APPENDICES . . . . . . . . . . . . . . . . . . . . 145

A COMPARABLE CASES................ 145

B THE MANSON SURVEY . . . . . . . . . . . . 167

C MASS MURDER SURVEY. . . . . . . . . . . . 172

D RECOGNITION POLL. . . . . . . . . . . . . 177

E RESULTS OF THE COMPARABLE CASES . . . . . . . 183

F RESULTS OF THE MANSON SURVEY. . . . . . 203

G RESUltS OF THE MASS MURdeR SURVEY . . . . . 212

H RESULTS OF THE RECOGNITION POLL . . . . . 220

I RESULTS OF THE CONTENT ANALYSIS . . . . . . 223 


\section{LIST OF TABLES}

TABLES

PAGE

I Aspects of the Manson Case Mentioned By at Least $10 \%$ of the Subjects. . . . . . 64

II Should the Defendants Be Paroled?. . . . . 67

III What Should Have Happened to the Defendants?. 67

IV Ratings on Horribleness and Bizarreness . . 70

$\checkmark$ Single Most Frightening Thing About the Case. 71

VI Mass Murderers Identified By at Least Ten

Percent of the Subjects. . . . . . . 72

VII Items Which Fall in the Confidence Interval With Manson. . . . . . . . . . . . 84

VIII Rankings From 1-13 on Horribleness. . . . . . 94

IX Citations of Comparable Cases....... . . 96

X Manson's Image. . . . . . . . . . . . 98

XI Follower's Image.............. 100 


\section{CHAPTER I}

\section{INTRODUCTION}

On August 9, 1969, police officers responded to a report of a possible homicide in the posh Bel Aire district of Los Angeles, California. They were not prepared for what they were to find at 10050 Cielo orive.*

The telephone wires had been cut and were hanging free near the gate. In the driveway, in a white Rambler, was Steven Parent, an eighteen-year-old who had been visiting the caretaker of the residence. He had one defensive slash wound, which severed his watch band, and had been shot four times. Two more bodies were found on the lawn. The first body was that of Abigail Folger, the twenty-five-year-old coffee heiress. She had been stabbed twenty-eight times. The second was a thirty-two-year-old male, Voytek Frykowski, a friend of Roman Polanski, and Abigail Folger's lover. He had been shot twice, struck over the head thirteen times and stabbed fifty-one times. On the front door of the house 'PIG' was written in blood. In the living room were two more bodies. They had been bound together with a rope

Information contained in the Introduction was obtained from Atkins, 1977; Bugliosi \& Gentry, 1974; Sanders, 1971; and Watson, 1978, unless otherwise noted. 
which was strung over a ceiling beam and tied around their necks. The first was a thirty-five-year-old male, Jay Sebring, a Hollywood hairstylist. He had been shot once and stabbed seven times. There was a bloody tower over his face. The last victim was a twenty-six-year-old female, actress Sharon Tate, the wife of film director Roman Polanski. It was in their home that the massacre occurred. Sharon was in her eighth month of pregnancy, and she had been stabbed sixteen times. As police continued their search of the grounds, they approached the guest house, behind the main house and the pool. They heard a dog barking and someone trying to quiet it. That someone was William Garretson, the nineteen-year-old caretaker of the property. He was promptly arrested for the murders.

On August 10, 1969, a grocery-store-chain owner and his wife were found dead in their home in the upper middle class Los Feliz district of Los Angeles. Forty-four-yearold Leno Labianca was found in the living room, he was on the couch. His hands were tied behind his back, he had a pillow case over his head, and a lamp cord tied around his neck. A carving fork was protruding from his stomach, and a knife had been stuck in his neck and left there. He had been stabbed twelve times and had fourteen puncture wounds made with the carving fork. 'WAR' had been carved on his stomach. In the bedroom was thirty-eight-year-old Rosemary Labianca. She had a pillow case over her head and a lamp 
cord tied around her neck. She had been stabbed forty-one times. In the living room 'DEATH TO PIGS' and 'RISE' were written on the wall in blood. 'HEALTER SKELTER' was misspelled on the refrigerator door, also in blood.

There were a number of similarities between the two incidents. They occurred on consecutive nights, in the same city. The victims were affluent caucasians. There were multiple victims in each case. The murders were quite brutal, with multiple stab wounds inflicted on both occasions. Victims had been found with a rope or cord around their necks, but not strangled. Messages were left at both scenes, both written in the victim's blood, both containing the word 'pig'. Small thefts were noted at each residence, primarily of cash, while items of greater value were left behind. Jay Sebring was wearing a watch worth more than $\$ 1,500$.

These murders were immediately linked in the press. The Los Angeles Police Department was quick to issue an official denial of any connection between the two events, with the possible exception of the second murder being a 'copy cat' crime. A great amount of information about the Tate murders had been leaked to the press. There was some concern that it might be difficult to determine the validity of any confessions. It is common practice for the police to withhold certain pieces of information that could only be known by someone who was involved in the crime, the theory 
being that an individual who does not know these things or gives contradictory information must be falsely confessing. Few such details had been kept from the press. It would have been possible to commit a similar crime.

There were some dissimilarities as well. The murderer or murderers had brought weapons with them to the Tate residence. The majority of the injuries sustained by the Labiancas were inflicted with cutlery from their own kitchen. Neither of the Labiancas had been shot, while three of the five Tate victims had been shot. The Labiancas were not celebrities and were in no way connected with those social circles. The major reason for discounting the similarities was the presence of drugs at the Tate residence and the conclusions drawn from that fact. Although it had not yet been made public the only suspect, william Garretson, had been cleared as the result of a polygraph examination. The new theory, which was the working theory until the actual killers had been identified, was that the murders at the Tate residence were the result of a drug transaction in which one of the parties decided not to honor the deal. Two separate investigations ensued.

While the autopsies were in progress, homicide detectives from the Los Angeles Sheriff's office consulted a detective who was working on the Tate case. They told him they were working on a homicide which could be related to the murders of Sharon Tate and her friends. On July 31 , 
1969, a friend of a man named Gary Hinman called the Los Angeles Sheriff's office. He was concerned because he had been unable to reach Gary after trying for several days. Gary Hinman, a thirty-four-year-old musician, was found dead in his Topanga Canyon home. He had been stabbed to death. On the living room wall, near the body, 'POLITICAL PIGGY' and a palm print were found, both in the victim's blood. A suspect was arrested on August 6 , 1969 , three days before the discovery of the Tate victims. The officers did not think that the man they arrested had been acting alone. The suspect, Robert Beausoleil, was arrested while driving Gary Hinman's car. There was blood on his clothing and a knife with blood on it was found in the tire well. "He had been living on a ranch near Chatsworth, north of Los Angeles, with a group of young hippies. These young people had gathered around a man named Charlie. Since the Tate detectives were convinced they were working on a high level, high finance, drug transaction, they were not very interested in a group of hippies. The officer did not even consider the information important enough to cross the autopsy room to report it to his superior officer.

On August 12, 1969, the media covered the release of William Garretson. Fear mounted despite the denial of any connection between the two murders. Los Angeles was frightened. In two days, a Beverly Hills sporting goods store sold two hundred firearms. They averaged three or four 
such sales per day before the murders. Some private security forces first doubled and then tripled their personnel. Guard dogs were selling for $\$ 1,500$ that had previously sold for $\$ 200$, and supplies quickly ran out. Locksmiths were quoting delays of two weeks on orders. Accidental shootings and suspicious-persons reports suddenly increased. Some celebrities went into hiding and turned their homes into veritable fortresses.

The press coverage was considerable. It focused on the first incident for the most part. The three major areas of interest were the physical evidence, the lifestyles of the victims, and speculation about what had happened and who might have committed the murders.

The physical evidence was reported with widely varying accuracy. Half statements by officials were taken as fact and expanded upon. In the August 22, 1969, issue of Time it was reported that Sharon Tate and Jay Sebring had been sexually mutilated, that Sharon was nude and Jay was wearing the torn remnants of a pair of boxer shorts, and that voytek had been found with his pants around his ankles. The same article reported that there were numerous bullets embedded in the walls and ceiling, and that the stab wounds had been made with a swordlike instrument, not a common knife. The most widely reported piece of misinformation (it was even reported in the conservative New York Times on August 10 , 1969), that Jay Sebring had a hood over his head, was 
included. All of this was totaliy unfounded. These reports pale when compared to reports that are to be found in less responsible publications.

There was some truth to the stories about the victims' lifestyles. Small amounts of marijuana and cocaine were found at the Tate house. As a result of the autopsies it was learned that Abigail Folger and Voytek Frykowski had both taken MDA, methylenedioxyamphetamine. Jay Sebring was rumored to have practiced bondage and 'mock' sadism, not actually inflicting pain but asking his partner to feign pain. These rumors were borne out in police interviews with women who had been intimate with him. Roman Polanski made films which dealt with the violent, the bizarre and the occult. Sharon acted in films that dealt with the same subject matter, including Roman Polanski's movie The Fearless Vampire Killers. Some differences between the lifestyles of the victims and the lives led by most people were due to the status and resources of the victims. Most people do not jet to the South of France with Warren Beatty. When the furor abated it was found that the general tenor of the victims' lives was disappointingly normal. Sharon Tate spent most of her last day dealing with workmen who were painting the nursery, planning a birthday celebration for her husband, feeding a stray kitten with an eyedropper and dining with friends at a restaurant.

Roman Polanski held a press conference in which he 
attempted to defend the honor of his dead wife. He later led a reporter and photographer from Life magazine through the house at 10050 Cielo Drive (Thompson, 1969). In his grief and anger at the sensationalism and speculation that surrounded the case he hoped to dispel rumors. Unfortunately, he only succeeded in creating further opportunities for rumors and theories to be printed.

In the absence of much hard evidence speculation ran rampant. Who had committed the murders, what exactly had happened and why it had occurred were the major points of interest. The theories ranged from a drug transaction that had gotten out of hand, the consequences of picking up 'rough trade' on Sunset Strip, a friend 'freaking out' at a party, to an occult ritual. These and similar theories were widely printed. Although they reflect a wide spectrum of fears, they generally have one thing in common, they place the blame squarely in the lap of the victims. The general tenor of these writings is best described by a line from an article from The New York Times Magazine (Roberts, 1970): "The attitude was summed up in the epigram: 'Live freaky, die freaky'." On December 1, 1969 Esquire was forced to cancel an article detailing twe rve theories about the Tate murders. On that day the Los Angeles Police Department announced that they had solved the Tate-Labianca murders. Reporters at the press conference were astounded to hear the two cases 1 inked after the protestations that arose from 
earlier attempts to connect the two incidents.

Warrants were issued for the arrest of Charles (Tex) Watson, age twenty-four; Patricia (Katie) Krenwinkle, age twenty-one; and Linda Kasabian, age twenty. Others to be charged with the seven murders were, Susan Atkins (Sadie Mae Glutz), age twenty-one; Leslie Van Houten, age twenty; and Charles Manson, age thirty-five, who were already in custody on unrelated charges.

Susan Atkins had been arrested as an accomplice in the murder of Gary Hinman. While she was awaiting trial she told two cellmates about the Tate and Labianca murders. As a result of interviews with Susan's cellmates, Susan's subsequent Grand Jury testimony and interviews with Manson 'Family' members and acquaintances, some questions were answered and the suspects were arrested and charged. Each of the defendants were charged with one count of conspiracy to commit murder. Leslie Van Houten was charged with two counts of murder, and the remaining defendants were charged with seven counts of murder.

The press had two new topics to cover. There were now first-hand accounts of the murders of Sharon Tate and her friends and second-hand accounts of the murders of the Labiancas. What proved to be the topic of greater interest was the defendants and the life they led.

Susan Atkins had given graphic testimony to the Grand Jury concerning the two nights of murder. She had also 
made a lengthy taped confession to her lawyer. Despite a court order prohibiting the release of such information, the confession was printed, first in The Los Angeles Times, and then copied by papers around the world. A paperback book, The Killing of Sharon Tate by Lawrence Schiller, was published in January 1970.

On the first night, Tex Watson, Patricia Krenwinkle, Susan Atkins and Linda Kasabian went to the residence at 10050 Cielo Drive, reportedly at the behest of Charles Manson. They were dressed in dark clothing and they had brought a change of clothing, three knives, a .22 revolver, a forty-three foot eight inch length of rope and a pair of bolt cutters. Once at the house, Tex cut the phone wires and they climbed over the fence, avoiding the gate in case it was wired to an alarm or was electrified. A car came down the driveway. Tex went to the car while the girls hid. He shot the driver and pushed the car back up the drive to a point where it could no longer be easily seen from the street. They went to the house and checked for a route of entry. Linda went to the car to serve as a lookout. Tex cut a screen over a window and entered the house. He went to the front door and let Patricia and Susan into the house. Voytek was asleep on the couch in the living room. They woke him. He asked, "Who are you? What do you want?" Tex said, "I am the Devil. I'm here to do the Devil's business." This was followed by the less-reported addendum, 
"Give me all your money." Susan then brought Abigail, Jay and sharon into the living room from the bedrooms. They were then bound with the rope. When Jay objected to the rough treatment sharon was receiving, mentioning her advanced state of pregnancy, he was shot. Money was further discussed. Although there was little cash in the house, the intruders declined offers to go get more money. Jay began to moan. One of the women asked what was going to happen to them. Tex said, "You're all going to die." Panic set in and a frenzy of stabbing, shooting, and bludgeoning followed. Accounts of who was responsible for which injuries vary, but Tex and Patricia are usually credited with the majority of the mayhem. At some point, Voytek and Abigail broke free and were eventually caught and killed on the lawn. Jay and Sharon were killed in the house. Sharon was the last to die, stabbed to death as she pled for the life of her unborn baby. They took seventy dollars which the victims had in cash, wrote 'PIG' on the front door in blood, and went home.

On the second night, Tex Watson, Patricia Krenwinkle, Susan Atkins, Leslie Van Houten, Linda Kasabian, Steve Grogan and Charles Manson got into the car and left Spahn Ranch in search of a place to repeat their crime. As the evening progressed they found and rejected several possible locations. They finally settled on a house which was across the street from a house that had once been rented by an 
acquaintance. Charles Manson and Tex Watson went into the house. Charlie bound Leno Labianca's hands and asked if there was anyone else in the house. His wife, Rosemary, was in the bedroom. Charlie brought her into the living room. They asked the couple if they had any money. When it became apparent that charlie was disappointed with the amount of money he found, Leno offered to go to his store and get more. The offer was declined. Rosemary was taken back into the bedroom where her hands were bound. Tex took the pillow cases off of the pillows. He put the cases over the Labiancas' heads and tied lamp cords around their covered heads, attempting to gag them. Charlie left the house, taking Rosemary's wallet with him. Patricia and Leslie came into the house. Leno was the first to die. Rosemary was in the bedroom where she could hear Leno cry out as Tex stabbed him. When Tex came into the bedroom she was swinging the lamp, which was still tied to her head, in an attempt to keep her attackers at bay. All to no avail. Each of the three intruders stabbed her. The finishing touches were added as Tex showered. Patricia stabbed Leno Labianca repeatedly with a carving fork, leaving it protruding from his stomach. They wrote on the walls and refrigerator door in blood, changed clothes, ate, stole a bag of coins and then hitchhiked back to Spahn Ranch. Meanwhile, Charles Manson, Susan Atkins, Linda Kasabian and Steve Grogan drove to what they thought was a black neighborhood. There they left the 
wallet in the restroom of a service station, complete with credit cards. They drove on looking for other possible sites for murder. After a few, seemingly halfhearted aborted attempts, they went home.

The press coverage of the details of the murders was relatively minor when compared to the attention received by the other new topic of interest, the defendants and the life they led.

Charles Manson was born out of wedlock to an ill-prepared, irresponsible sixteen-year-old girl with a penchant for men, alcohol and minor crimes. She spent most of her time trying to divest herself of the child. She would leave him with neighbors for an hour, but not return for days or weeks. He was usually collected by his grandmother or aunt, with whom he lived between his mother's erratic appearances. He began his own criminal career quite early. When he was released from prison on March 21, 1967, he had spent at least half of his life in various correctional institutions. His offenses ranged from forgery to violation of the Mann Act, but were primarily property crimes.

Shortly after his release from the federal prison at Terminal Island, near Los Angeles, he moved to the HaightAshbury district of San Francisco. He had not been a part of free society since June 23, 1960. He was just in time for what the newspapers would call the summer of love. He was taken by the lifestyle and the openness of the people 
he met. It is difficult to remember, but important in this case, what life was like in the summer of 1967. An illustrative passage can be found in The Family by Ed Sanders:

On the Haight, Manson encountered the entire col-. lection of subcultural currents that had been building up in the United States during the previous decade. Acid music. Dope. Sexual freedom. Peace rallies. Provos. Guerrilla Theater. Communes. Long hair. The concept of the underground superstar. Astrology. The occult. Underground newspapers. Crash pads. Dayglo art (p. 37).

Guitar in hand, and armed with a mystical patter that suited the times, he began to collect a small following. This group was then, and would remain, mostly women. In the fall of 1967 they left San Francisco. They traveled in a Volkswagon bus which was abandoned for a school bus as their numbers grew. They ventured as far as Alabama picking up new people and leaving behind those who did not fit in. But Cal ifornia was home.

By the summer of 1968, a core group of between twenty and thirty people had formed. There were a number of others who spent time with the 'Family', coming and going but never entering the inner circles. Even more people spent short periods of time with them, some leaving of their own accord others being asked to leave.

Sometime in late August, 1968 the 'Family' first came to Spahn Ranch, located in Chatsworth, north of Los Angeles. Its owner was George Spahn, a nearly blind, eighty-one-yearold semi-invalid. It had once been used as a location for 
movies and still sported an old west mainstreet. It had long since fallen into disrepair. The only income came from the rental of riding horses and the occasional B movie or commercial that was shot there. They agreed to help repair the ranch and take care of the horses in exchange for staying there.

The only psychology journal article written about the Manson 'Family' is about their life at Spahn Ranch (Smith \& Rose, 1970). Both of the authors had treated members of this group at the Haight-Asbury Free Clinic and Alan J. Rose had lived in this and other communes briefly prior to writing the article. While their lifestyle was definitely not mainstream, the investigators saw no remarkable difference between this and other group-marriage-type communes.

So, they lived together on the ranch. They ate together, took drugs together, sang together, stole cars and credit cards and anything else they wanted together, had orgies together, made dune buggies together, planned for Armageddon together, and frequently listened to Charlie together.

On August 16, 1969 the Los Angeles Sheriff's Office conducted a raid on Spahn Ranch. Twenty-six people were arrested and charged with auto theft. They were soon released however, when it was discovered that the warrant had been misdated. Shortly thereafter the 'Family' moved to Death Valley. On October 10, 1969 twenty-four people were 
arrested in Death Valley and charged with auto theft and arson. Among those arrested were Charles Manson, Susan Atkins, Leslie Van Houten and Patricia Krenwinkle. Patricia was released before the connection between the Tate-Labianca murders and the Manson 'Family' was made. She fled to her aunt's home in Alabama where she was later arrested. She fought extradition unsuccessfully and was returned to Los Angeles to stand trial. Tex Watson and Linda Kasabian had left the group prior to the move to Death Valley. Linda surrendered to police in New Hampshire when she learned that a warrant had been issued for her arrest. Tex fought extradition from his home in Copeville, Texas. He managed to avoid extradition long enough to avoid being tried with the others. He was later tried separately for the Tate-Labianca murders.

This 'hippy clan' made headline news around the world, and no less so when the trial finally began on July 24 , 1970, nearly a year after the murders. The trial was a nine-and-a-half-month-long circus. It was filled with courtroom antics, devout followers holding a vigil in front of the Hall of Justice, women with shaved heads and X's on their foreheads (following Charlie's lead), defense lawyers making a mockery of the judicial process, and amazing feats of journalistic imagination. Charlie and his 'Family' were not averse to the chaos and attention it garnered. Manson conducted a radio interview by telephone while he was in 
prison awaiting trial. He also wrote a series of articles for The Los Angeles Free Press. His activities were curtailed when he was later denied the privilege of conducting his own defense.

During the course of the trial, the state called eighty-four witnesses, some of them testifying for several days. When the state rested its case, perhaps the greatest surprise of the trial occurred. The defense rested without calling a single witness. This was done to prevent the three women co-defendants from taking the stand. They intended to confess to the murders, thereby absolving charlie of all guilt. They were offered the chance to testify without the jury being present. They declined the offer. Instead, Charlie took the stand. Out of the presence of the jury, he delivered a monologue. He seemed to view it as his chance to convey a message to the world. When he finished he told the women that they did not have to testify. On April 19, 1971, Judge Charles H. 01der pronounced sentence: the death penalty for all defendants.

But the story does not end here. There are a number of reasons for this. High on the list are further trials, continued criminal activity on the part of people who were associated with Charles Manson, and an image that was found to be irresistible.

Several trials followed the Tate-Labianca trial where Charles Manson and three co-defendants were convicted. Tex 
Watson was later tried separately for the Tate-Labianca murders, and found guilty. Charles Manson and various other members of the 'Family' were tried in connection with the murder of Gary Hinman, and the murder of Donald 'Shorty' Shea, who had worked at Spahn Ranch. All were found guilty to some degree. The usual requests for new trials were filed. Leslie Van Houten was the only defendant to be granted a new trial. Her first retrial in 1977 resulted in a hung jury. Her second retrial in 1978 resulted in a second conviction. She was sentenced to life, the final fate of all of the defendants, as California's death penalty was overturned in 1972. Leslie Van Houten was free on bail between her two retrials. The first parole hearings came in 1978, per the law, and are repeated yearly. This however is really only a matter of form.

It is difficult to know which criminal activities that have been attributed to the 'Family' can really be attributed to them. The following incidents however, are a matter of legal record. During the original Tate-Labianca trial, five members of the 'Family' took another member of this group, Barbara Hoyt, a prospective witness, to Hawai

There they gave her a hamburger laced with a liberal dose of LSD and left her to wander the streets. In 1971, six members of the 'Family' were thwarted by police in an attempt to rob the Western Surplus Store in a suburb of Los Angeles. When the police arrived the thieves had already loaded more 
than one hundred firearms into a waiting van. A ten-minute gun battle ensued in which several of the robbers were wounded slightly. In 1971, members of this group were involved in the escape of Kenneth Como, a one time associate of the 'family', from the Hall of Justice in Los Angeles. In 1972, three 'Family' members, among others, were connected with the murder of a young couple who had been staying with them. One of the suspects in this case was Lynette 'Squeaky' Fromme. In 1975, Squeaky was arrested when she attempted to assassinate President Gerald Ford. Her roommate was Sandra Good, another of the original members of the 'Family'. Sandra took this opportunity to deliver an antiestablishment message. This included threats mailed to various corporate heads. The threats eventually ended in her incarceration. When she was recentiy offered parole on the condition that she not associate with other members of the Manson 'Family', she said that she would rather stay in prison with her friends.

In a conversation with a subject who had completed a questionnaire for the present study, he said, "The reason this case became so famous is that it makes such a good script." Indeed, this is so. The first showing of Helter Skelter on television attracted fifty-seven percent of the viewing audience in New York City (The New York Times, August 5,1975$)$. A television critic for The New York Times noted the same sentiment in his review of the movie: 
It was, after all, a made-for-America murder case, what with sexual bondage, revolutionary rhetoric, narcotics, the rich heiress, the beautiful actress, the unborn child, the famous hairdresser. Naturally, Manson would want to be a rock star. Naturally, Roman Polanski's bad dreams would come true. (Leonard, Apri1 11, 1975).

But it was more than the lurid details. Every murder has its share of lurid details, and many are at least as horrifying and bizarre. The real interest began when the first reporters came to Spahn Ranch, but it matured in the courtroom. The elements were there to one extent or another. It was Vincent Bugliosi, the chief prosecutor, who welded them into a tidy package for mass consumption. The image was born.

My own interest in the Manson case began when the case was first reported in the newspapers. It seemed that there was something important about that event. This interest was reawakened in 1976 when I was involved in physiological research, and began to look at the physiological bases of aggression. It soon became apparent that there were certain acts of aggression which were not amenable to a purely physiological explanation. I began to look at the Manson case as an example of a senseless murder. After reading Helter Skelter (Bugliosi \& Gentry, 1974), and The Family (Sanders, 1971), new questions arose which went beyond the physical act. Why did this case attract so much attention? Why do people still find it of interest? How much do people know about this case? 
One of the most difficult aspects of this study was focusing on a managable set of questions. The data reflects this difficulty. Partially by serendipity and partially by design, important issues other than those being directly studied were addressed. Since this is a continuing interest items that do not specifically pertain to questions asked by this study, such as the second section of the mass murder survey, were included. Though all of the data gathered was not utilized in the present study, a complete data set has been provided in the appendices as an aid to further research. Some of the better sources of information about mass and serial murder were cited in the general bibliography for the same reason.

The study of an event like the Manson incident presents all the familiar problems of the non-manipulative field sciences. The subject is a natural event which must be understood on its own terms. It cannot be brought into the laboratory and it cannot be reproduced. It is like the events studied in astronomy, geology, field biology (including most of ethology) and all the historical sciences, including archaeology and paleontology. Further, it is like the events studied in such sciences which have a particularly intense and unusual effect: like a nova to an astronomer or a volcano to a vulcanologist.

A vulcanologist can only be alert to the possibility of an eruption. When one occurs, the investigator brings 
every instrument to bear and makes every measurement possible in hopes of finding a pattern which will tell something about volcanos. When the eruption subsides, the pattern is studied, methods are revised, and the wait begins for the next incident.

The Manson incident is a kind of cultural volcano. It was intense and produced a lasting effect on the imagery of crime and violence. It was widely regarded as having a powerful cultural effect by contributing to the end of one of the decades of cultural experiment and change in this century.

It is impossible to ignore as a phenomenon, but difficult to study in the tradition of 'rationalist' and 'empiricist' science, as those words are commonly used (Packer, 1985). For this reason, the study of such events has rarely occurred and there are few models. A rare example is the work of Foucault and his students (1975). Most other examples are studies of the murderer and not the incident and its effects (Eveseeff \& Wisniewski, 1972; Galvin \& MacDonald, 1959; and Kahn, 1960). Much of the research done for the present study required breaking new ground.

If the assessment of the effects of the Manson case are even partly correct, the event does merit attention. This thesis will attempt a study which depends on field research methods and which falls on the boundary of two methodological approaches: the 'rationalist' and 'hermeneutic' 
(Packer, 1985). In the first tradition, the data collection will follow the methods of field survey by questionnaire and other self-report. In the second, the methods of 'unobstructive measurement' like archival search and content analysis of records will be used; and the event will be considered in the context of its times and the response to it by mass communication media and other social forces. The hermeneutic principle of interpretation in context will be applied.

The present study addresses three major issues with regard to the Manson case.

The Popular Image

How familiar are people with Charles Manson and the acts which brought him to public attention? What do people know and feel about the man and the case?

The Media Image

What was the nature and extent of coverage of this event in the popular press? Is the media image the same as the popular image; does the popular image mirror what was written about the case? How does the press coverage of the Manson case compare to the press coverage of similar cases?

\section{Mythic Proportions}

Why is this case still of interest? Why does the mere mention of the man's name cause people to become frightened? 
Is there one particular aspect of the Tate-Labianca murders that was so horrifying that it caused the case to receive the extent of coverage that it did, and in fact still does? 
REVIEW OF THE LITERATURE

Three distinct but related areas will be discussed in this chapter. The first area is the Manson case. Both the extent and the nature of the coverage of the Manson case will be explored. The second area is mass murder. This will be an overview of the literature pertaining to the subject of mass murder. Lastly, twelve cases which compare to the Manson case, with regard to a particular salient aspect, were selected for purposes of comparison by questionnaire. The questionnaire and its purpose will be discussed in the following chapter. The selection of the twelve cases is discussed here.

Many of the writings referred to in this chapter are popular literature. That is because little else has been written about mass and serial murder.

\section{The Manson Case}

The Extent of the Literature. The Manson 'Family' and the murders for which they have become famous have attracted a great deal of attention. From the day that the bodies of Sharon Tate and her friends were discovered, August 9, 1969, through 1984, nine books have been written about the Manson 
case (Atkins, 1977; Baer, 1972; Bishop, 1971; Bugliosi \& Gentry, 1974; Livsey, 1980; Sanders, 1971; Schiller, 1970; Watson, 1978; and Zamora, 1976), sixty-eight magazine articles on this subject are listed in Reader's Guide (see Bibliography B), and The New York Times covered various aspects of this case on two hundred and ninety-seven days over the same time period (see Bibliography $C$ ).

Substantial portions of numerous books have been devoted to Charles Manson, the murders, or both. These writings tend to fall into two categories. The first category is condensed versions of the case. An example of this can be found in Bloodletters and Bad Men (Nash, 1973). The second category consists of attempts to analyze the man, the group or the murders. Many of these are quite poor. One such attempt can be found in Murder USA (Godwin, 1978). Brief references to the Manson case are made in far too many contexts to be accurately documented.

The above references only cover the more mainstream publications. There was a great deal of coverage in the underground press. These articles vary greatly in clarity, accuracy and bias. Perhaps the best of these articles, and certainly the most accessible, was printed in Rolling stone. In 1970, Rolling Stone was not the glossy, well-assimilated magaine that can be found on most newsstands today. At that time it was not among the publications listed in Reader's Guide. The June 25, 1970 issue featured a cover 
story entitied Charles Manson: The Incredible Story of the Most Dangerous Man Alive (Felton \& Dalton). The covers of other underground newspapers are reproduced in this article, and in Helter Skelter (Bugliosi \& Gentry, 1974). Included is a cover story from a Los-Angeles based paper Tuesday's Child entitled Man of the Year: Charles Manson. Reproductions of covers of copies of The Los Angeles Free Press appear in both places as well. A series of articles beginning in the January 30 - February 4, 1970 issue of this paper featured Charles Manson. The first offerings were interviews, these were followed by articles written by charles Manson from prison.

The Newspaper Coverage. This coverage tends to be largely factual in nature. This is no doubt due to a combination of limited space and a policy which reserves editorializing for the editorial page. There are two exceptions to this trend. Stories that appear in the sunday supplement are more lengthy and more analytical in nature. The coverage is more like that to be found in magazines. The other exception to the usually-brief, objective style of newspaper accounts is coverage in the city were the murders actually took place. This coverage is more extensive, more often relegated to the front page, and more analytical in nature. The Los Angeles Times frequently featured the Manson case with headlines in what is called 'end-of-the-world typeface', that is, very large and bold print. This is quite typical 
of the coverage of a spectacular murder case in the city where it occurred.

The Magazine Coverage. What was thought about the case and what was felt about the case are reflected in the magaine coverage far more than in the newspaper coverage. Newspaper accounts tend to begin with a string of adjectives which set the mood or provide background information for a particular point. An article about the three female defendants being removed from the courtroom would begin like this: Three young women members of the hippie family, headed by cult leader Charles Manson, were expelled from the Los Angeles courtroom today. Quite a bit of information, but not much depth. The difference in the coverage is that magazine articles expand on topics that are merely touched on in a newspaper account, such as: young, women, members, hippie, family, or cult leader. Two examples of the greater depth of fact may help to illustrate this difference. The 'Family' had its origins in the Haight-Ashbury district of San Francisco. This fact was mentioned in four percent of the articles from The New York Times (see Bibliography C), while it was mentioned in eighteen percent of the magazine articles listed in Reader's Guide (see Bibliography B). The Manson 'Family' moved to Death Valley shortly after the TateLabianca murders, where they were finally arrested. This was mentioned in nine percent of The New York Times articles and in thirty-two percent of the magaine articles. 
Along with these richer descriptions come biases that are rarely stated. However, when a magazine is a major publication, such as those listed in Reader's Guide, the general orientation of the publication is well known. To this extent the bias of an article can be surmised immediately. The coverage of the same topic by National Review and by Ramparts is going to be different in orientation. These biases were not totally unwelcome in the present study. A true representation of the thoughts and feelings about the Manson case, or any subject for that matter, must cover the spectrum from right to left. In fact, it is this sort of free-form speculation and analysis which forms the heart of this study. The physical facts, while of interest, have already been gathered and can be found elsewhere. The popular image of this case has less to do with the actual physical facts than it has to do with the conclusions which have been drawn from those facts.

Magazine articles tend to draw conclusions beyond the facts more frequently than accounts of the same subject in newspapers do. One of the conclusions which is drawn about this case is that Charles Manson is mentally unbalanced. This conclusion was reached in two percent of the coverage in The New York Times, while it was reached in twenty-seven percent of the magazine articles. Another such conclusion is that the murders were a sign of the times. This conclusion was reached in two percent of The New York Times 
articles, while it was reached in twenty-seven percent of the magazine articles.

In essence, due to the nature of magazine coverage, it tends to be a better measure of thoughts and feelings about the Manson case.

The Professional Literature. The Manson case has received a surprisingly small amount of attention in the professional literature. To be exact, there is one journal article and one book.

The journal article was written as a case study of a group-marriage-type commune (Smith \& Rose, 1970). Both of the investigators had treated members of the Manson 'Family' at the Haight-Ashbury Free Clinic. Rose had lived with this group at Spahn Ranch sometime in 1968. The Manson 'Family's' life at spahn Ranch is the subject of this case study. It is interesting to have this look at their life, especially since publication delays probably place the writing of this article before the arrests. It is of particular interest that the investigators found no remarkable difference between this group and similar groups. It must be taken into account that Rose was not a member of the inner circle of the 'Family' and was probably not privy to the entire behavioral spectrum of this group.

The only book which could be considered to be professional literature is The Manson Women: A "Family" Portrait (Livsey, 1980). Clara Livsey is a family therapist who 
asked to serve as a consultant for the prosecution in the second retrial of Leslie Van Houten, which she did.

She approaches the subject from her orientation as a family therapist with some interesting results. She has researched the family backgrounds of some of the more infamous of Charles Manson's associates. While these accounts are more in depth than most similar accounts, there are few real surprises, and the general tenor is the same as that of previous accounts.

of greater interest are her insights into the dynamics of the group. She looks at how the group formed, why they formed and what kept them together. Their journey from nonviolence to violence is also explored. In the process she examines some of the more common assumptions about the Manson case, such as: the followers stayed because they feared Charlie, Manson brainwashed his followers into committing the murders for him, and that Manson was some sort of mastermind with a coherent philosophy and focused goals. The following passage is indicative of the questioning and intelligent analysis which can be found in this volume:

These were women who wanted absolute freedom to act out their deviant yearnings, their hunger for continuous excitement or power or both. The orwellian double-speak of Manson suited them well because it did accomodate their own double intent, to yield to their yearnings while at the same time thinking of themselves as superior because they did. These daredevil women had reason to feel much safer within their group than they would have if they wandered alone or with transient companions. They had the ability to assess their situation and consequently 
realized what the Family and Manson had to offer them ( $p .26)$.

Other Books About the Manson Case. Out of the mass of writings about the Manson case, one book has emerged to be generally considered the definitive source about this case. That book is Helter Skelter, which was written by Vincent Bugliosi, the chief prosecutor in the original Tate-Labianca trial, in association with curt Gentry, who is a writer. It is without a doubt the most widely-read book about this case. It became a number one bestseller. It is an invaluable source of information about the investigation of the crimes and about the trial. The claim on the cover of this book: "Now, for the first time, we have the answers.", may be an overstatement. It becomes clear that the authors believe this statement, as have many others.

The majority of what has been written about the Manson case bears a striking resemblance to Helter Skelter. This includes articles and books which were published prior to. its release. This is less surprising than it might seem. The coverage of this case prior to the release of Helter Skelter drew heavily on the trial proceedings, and later the trial transcripts, which were largely a forum for Bugliosi's views, since the defense did not present a case. Subsequent writings draw on the trial transcripts and Helter skelter as sources.

The scenario of this book becomes abundantly clear when one looks at the index. There are two and one quarter pages 
of references to Charles Manson and two and one quarter pages of references to Vincent Bugliosi. Less than one quarter of a page is devoted to any one of the other defendants, or to any one of the victims. Clearly it is the story of how Vincent Bugliosi got his man.

The only other book about this case which sold widely was The Family (Sanders, 1971). He did a great deal of research into the 'Family' and some possible influences on this group. When reading this book, one has the uneasy feeling that the author may be going beyond his data. There are several possible explanations for this. Although he identifies himself as a 'data addict' in the introduction to the book, he does not see fit to provide an index. Unidentified sources are used. The occult ativities in and about Los Angeles receive a great deal of attention. Much of the material is sensational in nature. That does not mean that the contents of this book are false, merely that its contents cause one to feel cautious. When these cautions are observed, this book becomes one of the best sources for information about the 'Family' and the life they led.

Two books have been written by co-defendants, both of which were co-autored. These are child of Satan, Child of God written by Susan Atkins in association with Bob Slosser, and Will You Die For Me? written by Charles 'Tex' Watson in association with Chaplain Ray Hoekstra. Both are the selfserving documents one might expect. They cover the lives of 
the defendants, the murders and in each case the subsequent conversion to their present state as born again Christians. Each is an obvious ploy for parole.

While one must be guarded with regard to these accounts, they are not without value. First, they are the only accounts of the murders and of life in the 'Family' that we have from people who were actually there. Beyond that they provide insight into the individuals who wrote them.

Susan Atkins, unwittingly it seems, shows herself to be every bit the exhibitionist now that she was when she took the stand before the Grand Jury in Los Angeles in 1969:

The intensity in the stranger's black eyes deepened as he watched my movements. A smile curled about his lips. I slipped into one of my fantasies about Sharon King the dancer, the sensuous, long-legged, full-breasted movie starlet, the Broadway queen. The music penetrated the lower depths of my abdomen and up into my chest cavity. It possessed me (p. 65).

Tex Watson admits to committing the murders. In fact, by his account he did so almost single handedly. However, he makes certain we understand that it is the effects of drugs and the influence of Charles Manson that are really responsible for these acts.

One of the many effects of speed is to make the intention or thought of an action and that action itself almost inseparable, as if you leap ahead in time and experience your next move before you actually make it. There in that living room on the hill, with Charlie's instructions ticking through my brain, it was as if time telescoped, until one act tripped over the next in sudden bursts of blinding color and motion (p. 140). 
If you watch the spate of made-for-TV movies produced in the 1970's which deal with sensational topics such as teenage prostitution and selling babies, you will see the name Lawrence Schiller in the credits. Once you know this, you know what his book The killing of Sharon Tate is like. It was rushed to press nearly as soon as Susan Atkins finished her testimony to the Grand Jury. It is inaccurate, poorly written and highly sensationalistic.

Two of the three remaining books about the Manson case were written by jurors, the third was written by the wife of a juror. Of these, only Witness to Evil (Bishop, 1971) merits reading. From this book one can obtain information about the workings of the jury and other behind-the-scenes aspects of the trial. The author clearly puts the blame for the murders on drugs, LSD in particular. This is demonstrated in the preface as well as the text. The preface was written by Art Linkletter, whose daughter died while under the influence of LSD. Amid the dire warnings about the deleterious effects of drugs on young people and civilization as we know it, are a few items of interest.

The Underground Press. Much of this information is nearly inaccessible. Libraries tend not to have collections of underground newspapers. During the 1960's nearly every major American city had an underground newspaper, these have long since ceased publication. From accounts of others, it is clear that Manson appeared, at least briefly, to be a 
folkhero or a martyr. Tuesday's Child, a Los Angeles-based publication, had a cover story entitled Man of the Year: Charles Manson in their February 9, 1970 issue.

The closest thing to an underground newspaper which is still readily available is Rolling Stone. In the June 25 , 1970 issue of that magazine, one of the better in-depth articles from that time appears (Felton \& Dalton, 1970). It is well researched and features interviews with Charles Manson, Aaron Stovitz (one of the prosecuting attorneys), and various 'Family' members and acquaintances. Since large portions of the article are derived from interviews, one is able to draw one's own conclusions. The conclusions drawn in this article are of interest in and of themselves. They include some of the earliest documentation of the making of the myth; insights into how Charles Manson became a biggerthan-life villain.

\section{Mass Murder}

A comprehensive history of mass murder is not available. To construct a semblance of one, several sources are quite helpful (Gaute \& Odel1, 1979; Nash, 1973; Nash, 1978; Nash, 1981; Wilson, 1969; and Wilson \& Seaman, 1985). These books deal with many of the more spectacular and/or highly publicized cases of murder, some of which are mass murder. Mass murder is frequently spoken of as if it were a recent phenomenon. In fact, it is a time-honored tradition. 
The first well-documented case of mass murder is that of the Seany Bean family in Scotland. This family consisted of Seany Bean and his wife, and eight sons, six daughters, and thirty-two grand children. They lived in a cave on a major route to Edinburgh. They killed and ate hapless travelers. It has been estimated that they murdered as many as 1,500 people. They were finally caught in 1437 , when a potential victim escaped with his life as they attacked his wife. He brought others back with him and this family was taken to Leith where they were burned at the stake, without the benefit of a trial (Nash, 1981; and Wilson, 1969).

This lack of historical perspective is due in part to what seems to be an increase in mass and serial murder. An increase in this kind of murder is stated as fact quite frequently, but documentation of this assumption is not available. It does seem to be true, but it has received the same amount of quantitative attention as has been given to the subject of mass murder in general: very little.

There are a number of major obstacles to research in this area. First and foremost, mass murder is a relatively rare event. This presents problems in terms of obtaining a sizeable sample. It also places the researcher in a position which is common in the field sciences, waiting for an event to occur.

Once potential subjects have been identified the problems change and increase. Access to such murderers is 
limited. Everyone has the right to avoid self incrimination. Beyond this, they do not nave to talk to researchers. Also. we tend to further decrease our possibilities for gathering data by imposing the death penalty.

Mass murder research consists largely of single case studies conducted by psychiatrists who have been consulted to determine legal sanity. This causes some serious methodological problems. It is to the defendant's advantage to either withhold pertinent information which might be incriminating, or try to increase their chances of being found legally insane by assuming symptoms which they do not in fact have. Despite the problems, the few such studies are the best data available (Bruch, 1967; Eveseeff \& Wisniewski, 1972; Galvin \& MacDonald, 1959; and Kahn, 1960).

There is a tendency to view such murders as unique events. Indeed, each case has its share of spectacular idiosyncracies. There are aspects of these murders which make it tempting to focus on the peculiarities rather than on the similarities. That most succumb to this temptation is reflected in the names given to these murderers and cases by the press: the Trashbag Murders, the Skid-Row Slasher, the Co-ed Killer, the Yorkshire Ripper, and the Trunk Murders. While this sort of thinking sells books and newspapers, it brings us no closer to an understanding of mas murder and those who commit mass murder.

The majority of books which have been written about 
mass murder cover one case. Many of these are sensationalistic and inaccurate. There are a few notable exceptions. Before I Kill More (Freeman, 1955) is about William Heirens. He was apprehended in 1946, in Chicago, for three brutal murders. At the scene of one of these murders he left a note in lipstick, "For Heaven's sake catch me before I kill more". The book includes transcripts of interviews with the murderer, a rare inclusion in books of this type. Born to Raise Hell (Altman \& Ziporyn, 1967) is about Richard Speck who murdered eight nurses in their dormitory in Chicago, in 1966. Marvin Ziporyn was the consulting psychiatrist on the case, but he developed a deeper, more lengthy, relationship with the murderer than is usual. There are other books of this quality, but even those which are poorly written at the very least give an account of the case.

A few attempts have been made at a more overall view of this subject. One of the earliest can be found in Murder and Madness (Lunde, 1975). He divides these killers into two categories: paranoid schizophrenics and sexual sadists. These categories reflect the three cases on which he served as a consultant. While these categories may be viable, they are definitely not exhaustive.

A more emotional approach is taken in Murder USA (Godwin, 1978). Fearmongering aside, he has gathered a wide variety of murder cases, among them a number of multiple murders. He makes some attempts at analyzing such murders 
case by case, but offers no organized theories.

The most recent research of this type was done by Jack Levin and James Alan Fox, and is presented in their book, Mass Murder: America's Growing Menace. They based their book on forty-two cases of mass murder. From these cases they determined three major categories of mass murder: family slayings, mass murder for profit or expediency and killing for the sake of sex or sadism. They also developed a general profile of mass murderers:

He is typically a white male in his late twenties or thirties. In the case of simultaneous mass murder, he kills people he knows with a handgun or rifle; in serial crimes, he murders strangers by beating or strangulation. His specific motivation depends on the circumstances leading up to the crime, but it generally deals directly with either money, expediency, jealousy, or lust. Rarely is the mass murderer a hardened criminal with a long criminal record, although a spotty history of property crime is common. The occurence of mass murder often follows a spell of frustration when a particular event triggers sudden rage; yet, in other cases, the killer is cooly pursuing some goal he cannot otherwise attain. Finally, though the mass killer often may appear cold and show no remorse, and even deny responsibility for his crime, serious mental illness or psychosis is rarely present. Most unexpectedly, in background, in personality, and even in appearance, the mass murderer is extraordinarily ordinary. This may be the key to his extraordinary "talent" for murder: After all who would ever suspect him? (p. 47)

While this is a promising beginning, no statistical documentation is given for these assumptions. Once again, these assumptions seem to be true, and they are representative of thinking in the field. But one is left wondering exactly what typically white, typically male, typically in 
their twenties or thirties means. What are the percentages? Statements indicating surprise at the fact that mass murderers are ordinary people, with no outstanding outward signs of their predilection, are interesting. In 1876 , Cesare Lombroso, an Italian ex-army surgeon, gained some fame as a criminologist with his theory of criminal types. His examination of 7,000 criminals brought him to believe that such a thing as a 'born criminal' exists. They were characterized by physical features such as a heavy jaw, excessively long arms and an asymmetrical face (Gaute \& 0de11, 1982). We continue to grasp at straws with research such as that done on the $X X Y$ chromosome syndrome (Levin \& Fox, 1985). Why should we expect mass murderers to exhibit any more outward similarity to each other than any other group of people who share a common interest? It would, of course, be helpful if they all bore the mark of the beast on their foreheads and worked at a common profession.

More specific profiling has been done for some time in connection with the investigation of unsolved cases. This is sometimes done by private psychiatrists and psychologists. Casebook of a Crime Psychiatrist (Brussel, 1968) chronicles the work of one of the more successful of these professionals. Much of this work is now done by the Behavioral Science Unit of the FBI. An article in Psychology Today entitled Mind Hunters (Porter, 1983) looks at their work. Their profiles are much more specific and detailed than the one 
quoted here, which is to be expected since they are working with a single actual case. Many of these have proven to be quite accurate.

While it is important to sharpen our skills with regard to apprehending these murderers. it would seem that detection before the fact would be preferable. Research in this area tends to deal with the prediction of violent behavior in general (Hellman \& Blackman, 1966; and MacDonald, 1963). Again, common assumptions are made in writings about mass murderers with regard to precursors to this sort of behavior. In the afterword of Lust Killer (Stack, 1983), there is a brief account of such traits as demonstrated by mass murderers who are of the sexual sadist type. Frequently mass murders of this type are preceeded by lesser acts of a similar type. These include voyerism, fetishism and exhibitionism. Such murderers tend to have certain childhood experiences in common as well. These include neglect, physical and/or sexual abuse, an absent or functionally absent father, a domineering mother, a great deal of early rejection and early exposure to sexual activity either.as an observer or as a participant, often of an incestuous nature. This could possibly be the mark of the beast that investigators have been searching for in less fertile fields.

It seems surprising that such a small amount of basic research has been done in the area of mass murder. If viewed as one of the tails of a normal curve, it presents some 
intriguing possibilities for generalization to similar but lesser acts. While mass murderers are relatively rare, sociopaths are not.

\section{Comparable Cases}

As a part of this study, twelve murder cases were chosen for the purpose of comparison. Each of these cases has a salient aspect in common with the Manson case. As well as the particular salient point, criteria for selection were: the murder had to have happened not more than ten years prior to and not more than ten years after the Tate-Labianca murders, the case had to have been solved, and the murder had to have taken place in the United States. The actual accounts, as given to the subjects, can be found in Appendix A with the set of questions which was to be answered with regard to the case.

A Victim Who was a Celebrity. Such murders are relatively rare, as are celebrities. The Sal Mineo case was chosen because he was an actor, Sharon Tate was an actress, and because his degree of fame was comparable to Sharon's. A collection of such murders is available in Murder Among the Mighty: Celebrity Slayings (Nash, 1983), including an account of this case which served as the source material for the account used in the questionnaire.

A Pregnant victim. When pregnant women are killed they tend to be murdered by their husbands (Eveseeff \& 
Wisniewski, 1972; and MCGinniss, 1983). This is not very surprising since most people who are murdered are murdered by their intimates (Lunde, 1975). The murder of a pregnant woman by a stranger is less frequent and qualitatively quite different. The Norma Jean Armistead case was chosen because it involved the killing of a pregnant woman by a stranger. The facts of this case were obtained from Murder USA (Godwin, $1978)$.

Random Selection of Victims. The victims of mass and serial murderers are frequently chosen at random. White there is often a pattern to the victims, such as prostitutes, children, young women and vagrants, this is a crime of opportunity and the selection within these groups has more to do with availablity and vulnerability than it has to do with the particular person who becomes a victim. The randomness of selection is most apparent in simultaneous mass murder in a public place. While people are able to convince themselves that they can avoid other sorts of mass murder, this sort of mass murder makes it uncomfortably clear that anyone can be a victim. I could have been on that campus or in that fast food restaurant. For that reason the Robert Benjamin Smith case was chosen. The facts of this case were obtained from Almanac of World Crime (Nash, 1981).

Mutilation of Victims. Murder cases in which victims are mutilated are easily found. Many of these involve sexual mutilation, often accompanied by sexual sadism. Such 
cases were avoided because of the qualitative difference in the acts. Since the mutilation which occurred in the Manson case was relatively mild, extreme cases of mutilation were also disqualified. There is a difference between carving 'WAR' on the stomach of a victim and dismemberment. The Baniszewski case was chosen because the mutilation of the victim included writing on her body, although it was done by branding. The facts of this case were taken from The Basement: Meditations on a Human Sacrifice (Millett, 1979), a work of unusual sensitivity and insight, and Bloodletters and Bad Men (Nash, 1973).

A Large Number of Victims. A number of murders, both before and after the Manson case, have involved large numbers of victims. Surprisingly enough, many of these escape general attention. Henry Lee Lucas has confessed to killing three hundred and sixty people (Levin \& Fox, 1985; and Sonnenschein, 1985). Though news of his arrest coincided with the invasion of Grenada, it would seem to be of sufficient import to receive a great deal of coverage regardless of what else might be happening in the world. He remains relatively anonymous.

While the name Dean Corll is not well known, the murder case in which he was the primary murderer has received its share of coverage, at least by crime writers (Gaute \& Ode11, 1979; Gaute \& Ode11, 1982; Haines, 1977; Levin \& Fox, 1985; Nash, 1978; Nash, 1981; and Wilson \& Seaman, 1985). 
With the large number of victims (at least twenty-seven), and multiple murderers, various accounts were helpful in sorting out the case and writing a reasonable account. It was also felt that it was important to avoid using only cases which have remained fairly obscure.

\section{A Message Left at the Scene of the Crime. It is not} uncommon for bizarre murderers, which includes mass and serial murderers, to leave some sort of message. This is usually in the form of a diary, notes or in some cases graffition the walls of their residence. It is much less common for a message to actually be left at the scene of the crime. The most famous case of this sort is the case of William Heirens (Freeman, 1955). He left a message in lipstick at the scene of one of the murders for which he was responsible. The John Linley Frazier case was chosen partially because of the cryptic nature of the message (Lunde, 1975). Another form of sending a message to the world is correspondence with the authorities. Jack the Ripper, Son of Sam (David Berkowitz), and the Zodiac Killer all carried on active correspondence with the authorities. A note of interest is that two of these cases remain unsolved.

Repeated Multiple Murders. Mass murderers who kill a number of people on one occasion tend to be either captured or killed by police at the scene of a very public crime, the victim of self-inflicted gunshot wounds, or the only remaining member of a family. Serial murderers tend to murder a 
single victim or occasionally two victims on one occasion. It is quite rare for murderers to kill more than one victim per occasion, serially. The Steelman and Gretzler case is one of few. The facts of this case were taken from Murder USA (Godwin, 1978) and Murder America (Nash, 1978).

Domination by a Controlling Person of Vulnerable People Resulting in Murder. Many fratricides and sororicides are actually committed as a result of either covert or in some cases overt prompting by one of the parents (Godwin, 1978). other cases which loosely fit into this category are murders where, because of the relationship between the primary murderer and the accomplice, the accomplice becomes involved in a homicide. Such cases include the charles Starkweather case and the Lonely Hearts Killers (Gaute \& Odell, 1979; Nash, 1981; and Levin \& Fox, 1985). In these cases it is difficult to determine the degree of culpability of the participants. It is in the interest of the accomplice to assume as little guilt as possible, and they do. The Marlene 01 ive case was chosen because it is unlikely that the girl actually participated in the murders, though her boyfriend now maintains she did, and the degree of control over him is well documented (Levine, 1982).

A Leader who Has others Kill For Him. Outside of the sanctioned form of mass murder, otherwise known as war, this is an unusual event. Groups which might indulge in such practices, such as neo-Nazi groups, occult groups and 
various other extremist groups, act in secrecy as one might expect. When they are found to be murderers, responsibility for their acts tends to be diffused. While the Zebra case has some of these problems, it was a more public event. A member of the group detailed the group's activities which have been presented in some detail in the book Zebra (Howard, 1979).

Women Murderers. Only a small portion of all murders are committed by women. Even a smaller percentage of mass murders are committed by women (Levin \& Fox, 1985). Though the percentage of murders committed by women is lower than that of murders committed by men, these is no shortage of such cases. The Sandra Beam case was chosen because more than one woman was involved in committing the murder, as is true of the Manson case (Godwin, 1978).

An Ideological Motive. There have been a number of mass murderers who had an ideological motive. These range from the bizarre case of Herbert Mullins (Lunde, 1975) who killed as a sort of human sacrifice to prevent earthquakes in California, to the more common motive of racial hatred, as demonstrated in the Frederick Cowan case which was chosen for the present study (Godwin, 1978; and Nash, 1978).

Undesirables Killing Socially Acceptable People. Murder is typically committed within social classes (Lunde, 1975). Consequently, this is not a frequent occurrence. A good account of such a murder can be found in In cold Blood 
(Capote, 1965). The Alday family murder was chosen because of the status of both victims and murderers. The facts of this case were drawn from Murder USA (Godwin, 1978). 
CHAPTER III

METHOD

Subjects and Selection Criteria

A total of three hundred and seventy-eight unpaid subjects, two hundred and thirty females and one hundred and forty-eight males, were employed in this study. They ranged from eighteen to sixty-six years of age. The distribution of these subjects will be discussed in the following sections which deal with the individual questionnaires. These subjects were drawn from the undergraduate population at Portland State University and from psychology classes at Portland Community College.

Since this study is an investigation of an American cultural phenomenon, subjects who could not be considered to be a part of this culture were disqualified. This condition applied to foreign students who had been in this country for a brief period of time.

There were four questionnaires, one of which was administered in two forms. The various forms were given to several classes per term, over the course of a year. The nature of the study was frequently discussed with subjects after they completed the questionnaires. Consequently, when a subject indicated that they had previously been involved 
in this study their second response was disqualified. Given the sample size, it is surprising that this only occurred on two occasions.

The Manson Survey

A total of sixty-seven subjects were administered this questionnaire. There were forty females and twenty-seven males, ranging from eighteen to fifty-four years of age. Three age range divisions were made. These correspond to the dates of two events related to the Manson case which received extensive coverage in the press. Nineteen subjects were at least sixteen in 1969 when the Tate-Labianca murders occurred and Charles Manson and the other defendants were arrested, which made them thirty or over at the time of the survey. Nineteen subjects were at least sixteen in 1975 when Lynette 'Squeaky' Fromme attempted to assassinate President Gerald Ford but less than sixteen in 1969, which made them at least twenty-four but not over twenty-nine at the time of the survey. Twenty-nine subjects were under sixteen in 1975, which made them under twenty-four at the time of the survey.

When subjects were asked when they became aware of most current events and regularly watched the news or read the newspaper, the mean answer was found to be 14.87 years of age $(n=195)$. It was felt that this figure might be deceptively low. It did not take into account those who answered 
that they had never really been very aware of current events. It also included subjects who said that they were aware of most current events at ages as low as six. It seems doubtful that the average first grader is aware of most world events. The age of sixteen (i.e., one year older than the mean estimate by subjects) was felt to be a safe assumption for the age of general awareness of news events.

The purpose of the Manson survey (see Appendix B) was to assess the popular image of Charles Manson and the murder case with which he is associated. Much has been written, filmed, and said about the man and the murders. The task at hand was to determine which facts, feelings and pieces of misinformation have coalesced to form the image which comes to us when the name Charles Manson is mentioned.

This questionnaire is composed of two sections. The first section asks the subject to give their independent recollections of the man and the events that brought him to public attention. These recollections were to be written in the order that they occurred to the subject, a phrase or sentence which conveyed a single thought being written on one line, and the next thought being written on the next line, and so on.

The second section contains specific questions about the case and feelings that people have about the case. Some of these questions are designed to ascertain the views of subjects on certain crucial issues which they may or may not 
have covered in their independent account. These questions include: Why did this happen and what is the single most frightening thing about this case? Other questions were designed to quantify feelings about the man and the case. These questions include: Is Manson crazy and how does this event effect your feelings of safety?

\section{The Mass Murder Survey}

A total of eighty-nine subjects were administered this questionnaire. There were sixty-two females and twentyseven males, ranging from eighteen to fifty-five years of age. The age groups described in the section on the Manson survey were employed. Thirty subjects were thirty years of age or over, nineteen subjects were at least twenty-four but not over twenty-nine years of age, and forty subjects were under twenty-four years of age.

The mass murder survey (see Appendix C) served two distinct functions, which are reflected in the two sections of this instrument.

The first section asks the subject to identify every case of mass murder they are aware of. For purposes of the questionnaire, mass murder was defined as either the killing of a number of people on one occasion or the killing of one or more people by the same person on successive occasions. Subjects were instructed to give as much information as possible which might help to identify the case, such as: names of murderers, names of victims, names given to 
the murderer or the case by the press, approximate dates, where the murders occurred, method of killing, or patterns of victims.

The purpose of this section was to identify which actual cases of mass murder people are familiar with, and the proportion of subjects who were familiar with any one case. Of particular interest was the proportion of subjects who were familiar with the Manson case, and how that proportion related to familiarity with other cases.

The second section begins by asking subjects how many victims must be killed at one time and how many occasions a murderer must kill on for murder to be considered mass murder. The remaining eleven questions deal with different conditions under which a number of people might be killed. These conditions are: 1) if the victims are related to the murderer, 2) if a person kills repeatedly in the course of armed robbery, 3 ) if a person kills repeatedly in the course of rape, 4) military personnel being killed during a war, 5) civilians being killed during wartime, 6) military personnel being killed not at war, 7) civilians being killed not during wartime, 8) if the murderers are organized criminals, 9) if the murders are the result of a gang conflict, 10) if the murders are the result of terrorist activity, and 11) if the murderer is a hired killer. With regard to each of the conditions, subjects were asked: Is it mass murder? How do such cases effect your feelings of safety? 
In general, do you feel that such murderers are crazy? Would you classify this sort of murder as understandable or as senseless?

The purpose of this section was to determine when murder becomes mass murder, and under what conditions the taking of human life is generally considered to be mass murder, essentially to ascertain a popular image of mass murder.

\section{The Comparable Cases}

Twelve cases were chosen, each of which corresponds to a salient aspect of the Manson case. These particular aspects were identified as possible contributors to the notoriety of this case through preliminary results from the Manson survey. These aspects are: 1) a victim who was a celebrity (the Sal Mineo case), 2) a pregnant victim (the Norma Jean Armistead case), 3) random selection of victims (the Robert Benjamin Smith case), 4) undesirables killing socially acceptable people (the Alday family murder case), 5) mutilation of victims (the Gertrude Wright Baniszewski case), 6) a large number of victims (the Dean Corll case), 7) a message left at the scene of the murder (the John Linely Frazier case), 8) repeated multiple murder (the Douglas Gretzler and William Steelman case), 9) domination by a controlling person on vulnerable people resulting in murder (the Marlene 01 ive case), 10) a leader who has other people kill for him (the Zebra case), 11) women murderers 
(the Sandra Beam murder case), and 12) an ideological motive (the Frederick Cowan case). Further information about the selection procedure can be found in the review of the literature.

The comparable cases questionnaire (see Appendix A) was administered in two forms. In the first form, subjects were given one case to read and a set of questions to answer in regard to the case. In the second form, subjects were given thirteen cases, the twelve cases previously mentioned and the Manson case, each of which was accompanied by a set of questions.

A total of one hundred and fifty-five subjects were administered the first form of this survey. There were eighty-three females and seventy-two males, ranging from eighteen to fifty-seven years of age. These subjects were distributed among the cases as follows: the Manson case, six females and seven males; the Sal Mineo case, seven females and six males; the Norma Jean Armistead case, six females and six males; the Robert Benjamin Smith case, seven females and five males; the Alday family murder case, seven females and six males; the Gertrude Wright Baniszewski case, five females and four males; the Dean Corll case, six females and six males; the John Linley Frazier case, six females and five males; the Douglas Gretzler and William Steelman case, six females and five males; the Marlene 01 ive case, seven females and five males; the Zebra case, seven 
females and six males; the Sandra Beam murder case, six females and five males; and the Frederick Cowan case, seven females and six males.

A total of twenty subjects were administered the second form of this survey. There were twelve females and eight males, ranging from eighteen to forty-seven years of age.

The set of questions asked in regard to the cases was the same for all cases, and the same for both forms of the survey. These questions are essentially the same as those in the second section of the Manson survey. This was done to facilitate comparison. The purpose of these questions is to determine familiarity with the various cases, and to ascertain how feelings about comparable cases relate to feelings about the Manson case.

The Recognition Poll

A total of forty-seven subjects were administered this instrument. There were thirty-three females and fourteen males, ranging from eighteen to sixty-six years of age. Of these, fourteen were thirty years of age or older, eight were at least twenty-four but under thirty years of age, and twenty-five were under twenty-four years of age.

The items for the poll consist of the prinicpals in the twelve comparable cases and the Manson case, and control items. Five control items were chosen from the issue of 
The New York Times published the day that each of these thirteen cases came to public attention. The items were then randomly ordered.

subjects were asked to briefly identify any item that they were familiar with. For example: Jack Nicholson-actor. The purpose of the poll was to determine the name familiarity of the Manson case and the twelve comparable cases.

While the mass murder survey and the comparable case questionnaires require recall, this instrument only requires the subject to demonstrate recognition. It was felt that while subjects might not be able to give an independent account of a case, or identify a case from an account where the names had been removed, they might recognize a name to the extent that they could identify someone as a murderer or as a murder victim.

\section{The Media Coverage}

In order to determine the media image of the Manson case, a content analysis of magazine articles and newspaper items was done.

The magazine articles selected were those which had been cited in Reader's Guide from 1969 through 1984. There were sixty-eight articles in all. Of these, seven were pub1 ished prior to the arrest of the defendants.

The newspaper articles selected were those which had 
been published in The New York Times from August 9, 1969 through 1984. There were a total of two hundred and ninetyseven days of coverage. Of these, thirteen were prior to the arrest of the defendants.

Categories drawn from the results from the first section of the Manson survey served as a base for this content analysis. Additional categories were added as they arose.

In addition to the content analysis of the coverage of the Manson case, the number of citations in Reader's Guide, and the number of citations in The New York Times Index were compared for all thirteen of the comparable cases. This was done to determine if the extent of coverage given to the Manson case is typical of the coverage of such cases.

\section{Procedure}

All of the questionnaires were administered in a classroom setting. In some cases questionnaires were given at the normal meeting time for a class, in others subjects signed a list in a class indicating that they would be willing to participate in a study outside of a class. When questionnaires were administered outside of a class, all subjects came to a classroom at Portland State University which was reserved for this purpose.

In addition to the instructions and information about the nature of the questionnaire and how long it takes to complete, which accompanied all of the questionnaires (see 
the appropriate Appendix for each survey), the person who administered the surveys gave this information verbally.

Subjects were told that if they felt they needed to talk to someone after completing this survey, the person who was administering the survey would be available. While many subjects were interested in the topic and wanted to discuss some aspect of murder, only one person was upset by the content of the questionnaire and felt the need to talk to someone about it. This was one of the subjects who answered the questionnaire which included all of the comparable cases. This subject did not feel the need for any contact beyond a short debriefing. 


\section{CHAPTER IV}

\section{RESULTS}

A complete data set for all of the questionnaires and for the content analysis is available in appendices $F$ through I.

The results of the questionnaires will be discussed first, with particular emphasis to results that bear on the popular image, the media image and the mythic qualities of both.

The first section of the Manson survey was an indirect measure of the familiarity of the case. More importantly, it was the vehicle for determining the popular image of the Manson case. The second section of this questionnaire was designed to fine tune that image; to ask in a more specific way what do you think and feel about Charles Manson and the murders which brought him to public attention.

The mass murder survey was designed to determine the familiarity of subjects with actual cases of mass murder, and to ascertain how familiarity with the Manson case compared to familiarity with other such murders.

The recognition poll was designed to determine name familiarity with the principals in the Manson case and in the twelve other comparable cases. Name familiarity is a 
less exacting measure of familiarity than previous measures in that it requires recognition rather than recall.

The comparable case questionnaires were designed to ascertain if one particular salient aspect of the TateLabianca murders might be responsible for the notoriety of the Manson case, and to determine differences in the way people think of and feel about the Manson case and other murder cases.

The media coverage of the Manson case was analyzed in order to determine what the media image of Charles Manson and the murder case was. The extent of the coverage of the Manson case and the comparable cases was examined to ascertain any differences between the treatment of the various cases.

A note of explanation will help the reader interpret tables one through six.

By use of the binomial expansion, and using the sample size and the observed proportion of the sample making a response, it is possible to compute the upper and lower limits of the true proportion in the population from which the sample is drawn, at a given level of confidence. These estimated ranges, for different sample sizes, are tabulated in tables available in Statistical Tables (Rohlf \& Sokal, 1969).

In tables one through six, the proportion of response in the sample is shown as a percent. Beside each observed 
percent response is displayed the upper and lower limits of the percent in the population at the .05 level of confidence. The probability is $\leq .05$ that the true percent in the population will lie between the limits shown.

\section{The Manson Survey}

A complete summary of the results from this survey can be found in Appendix F.

Section I. The first important finding, with regard to this survey, was related to familiarity with the Manson case. Of the sixty-seven people given this survey, every person was at least familiar enough with this case to identify Charles Manson as having been associated with a murder. A few foreign students answered this survey. Although their responses were not scored, as this is mainly an American cultural phenomenon, half of those responding were familiar with the Manson case. This is an indication of its status as a world event.

The most frequently-mentioned aspects of the Manson case (see Table I) were all expected. The surprising results have to do with aspects which were mentioned less frequently. It was felt that the following aspects would be mentioned more frequently than they were: Manson is frightening (7\%), Manson's changing appearance (4\%), others were convicted of murder with Manson (6\%), Manson's criminal history $(6 \%)$, the defendants were unruly at the trial $(1 \%)$, the 
TABLE 1

ASPECTS OF THE MANSON CASE MENTIONED

BY AT LEAST 10\% OF THE SUBJECTS

\begin{tabular}{|c|c|c|}
\hline CATEGORY & $\begin{array}{l}\text { AMPLE } \\
\text { ERCENT }\end{array}$ & $\begin{array}{l}\text { POPULATION } \\
\text { RANGE P } \leq .05\end{array}$ \\
\hline \multicolumn{3}{|l|}{ MANSON'S CHARACTER } \\
\hline Unbalanced/Crazy/Sick & 43 & $29.10-57.76$ \\
\hline \multicolumn{3}{|l|}{ Thought He Was/Thought of as } \\
\hline A Diéty & 22 & $11.59-35.95$ \\
\hline Persuasive/Charismatic & 21 & $10.79-34.89$ \\
\hline No Remorse/Guilt & 10 & $3.52-21.82$ \\
\hline \multicolumn{3}{|l|}{ MANSON'S PHYSICAL ATTRIBUTES } \\
\hline Long Hair & 13 & $5.18-27.03$ \\
\hline Eyes/Scary/Penetrating & 12 & $4.54-24.31$ \\
\hline Beard & 10 & $3.32-21.82$ \\
\hline \multicolumn{3}{|l|}{ JUDICIAL MATTERS } \\
\hline In Prison & 36 & $22.93-50.80$ \\
\hline Came Up For Parole & 34 & $21.22-48.76$ \\
\hline Manson Convicted of Murder & 18 & $8.58-31.44$ \\
\hline Manson is Serving Life & 15 & $6.50-27.94$ \\
\hline Afraid He'll Be Paroled & 12 & $4.54-24.31$ \\
\hline \multicolumn{3}{|l|}{ VICTIMS } \\
\hline Sharon Tate & 45 & $30.90-59.71$ \\
\hline Pregnant Victim & 18 & $8.58-31.44$ \\
\hline Others Killed Besides Tate & 16 & $7.17-29.12$ \\
\hline Labianca/Other Couple & 15 & $6.50-27.94$ \\
\hline Famous Victini/Actress & 10 & $3.32-21.82$ \\
\hline \multicolumn{3}{|l|}{ CULPABILITY } \\
\hline \multicolumn{3}{|l|}{ Manson is a Murderer/Mass } \\
\hline Murderer & 64 & $49.20-77.07$ \\
\hline Followers Did it/Helped & 28 & $16.23-42.48$ \\
\hline Manson Ordered/Planned it & 25 & $13.84-39.27$ \\
\hline \multicolumn{3}{|l|}{ FOLLOWERS } \\
\hline Had Followers/A Group & 37 & $23.80-51.81$ \\
\hline They Would Do Anything For Him & 16 & $7.17-29.12$ \\
\hline Primarily Women & 16 & $7.17-29.12$ \\
\hline \multicolumn{3}{|l|}{ LIFESTYLE } \\
\hline Drugs & 12 & $4.54-24.31$ \\
\hline Unusual/Abusive/Free Sex & 12 & $4.54-24.31$ \\
\hline \multicolumn{3}{|l|}{ MANSON'S RELATIONSHIP TO FOLLOWERS } \\
\hline Cult Leader & $\overline{24}$ & $13.07-38.17$ \\
\hline Brainwashed Followers & 18 & $8.58-31.44$ \\
\hline Leader. & 13 & $5.18-27.03$ \\
\hline Hypnotic Control & 12 & $4.54-24.31$ \\
\hline Abnormal Hold & 10 & $3.32-21.82$ \\
\hline \multicolumn{3}{|l|}{ REASONS/INFLUENCES } \\
\hline To Start a Race War & 12 & $4.54-24.31$ \\
\hline Anti-Establishment & 10 & $3.32-21.82$ \\
\hline \multicolumn{3}{|l|}{ MEDIA RELATED ISSUES } \\
\hline Helter Skelter & 37 & $23.80-51.81$ \\
\hline
\end{tabular}


murders were bizarre $(4 \%)$, victims were stabbed to death $(6 \%)$, a fork was used to stab Leno Labianca and left protruding from his stomach (3\%), Lynette 'Squeaky' Fromme (9\%), 'Family' (9\%), Leslie Van Houten ( $1 \%)$, Susan Atkins $(0 \%)$, Patricia Krenwinkle $(0 \%)$, Charles 'Tex' Watson $(0 \%)$, communa 1 living (4\%), hippies ( $1 \%$ ), and that the case received a lot of coverage (4\%).

Section II. $88 \%$ of the subjects reported that they had learned of this case on television. In most cases, that would refer to television news, in this case it most likely refers to the movie Helter Skelter; this movie was specifically mentioned by $3 \%$ of the subjects. Word of mouth was the second most frequently-cited source of information about this case $(73 \%)$, this was followed by newspapers $(61 \%)$, books (57\%), magazines (33\%), radio (31\%), and classes $(3 \%)$. When asked why the murders happened, the overwhelming response was that Manson was crazy $(42 \%)$. This is a theme that runs through the results from the comparable cases as we11. The three next most cited reasons were related to the followers and Manson's relationship to them: Manson dominated his followers $(21 \%)$, the followers were weak and vulnerable (19\%), and Manson was a charismatic leader (15\%). That the murders were a part of a plan, a mission, was cited by $15 \%$ of the subjects. Drugs were seen as the reason by $12 \%$ of the subjects. The murders were seen as a sign of the times by $10 \%$ of the subjects. This is particularly 
interesting in view of the fact that only one of the subjects said that Charles Manson and his followers were hippies in the first section of this survey.

While all of the subjects were familiar with Charles Manson, few were familiar with anyone else related to this case $(12 \%)$. Two of these were followers: Leslie Van Houten $(1 \%)$, and Lynette 'Squeaky' Fromme (3\%). Two of these were lawyers: Vincent Bugliosi (1\%), and Ronald Hughes ( $1 \%)$. Three of these were victims: Sharon Tate (1\%), Abigail Folger $(1 \%)$, and Donald 'Shorty' Shea $(1 \%)$. One person just said that there were followers, and two misidentifications were made: Patti Hearst $(1 \%)$, and Leslie Krenshaw (1\%).

The responses to whether Charles Manson should be paroled are of particular interest in comparison to the responses to the same question with regard to the followers.

It is clear that there is a difference in feelings people have about Manson and feelings that people have about the other defendants. A Kruskal-Wallis H-test showed no significant difference between the age groups. A MannWhitney $U$-test showed no sex difference with regard to this question. The same tests revealed the same results for whether the followers should be paroled.

This difference in feeling toward Manson and the other defendants is further revealed by the responses given by subjects when they were asked what should have happened to Charles Manson and the other defendants. 
TABLE II

SHOULD THE DEFENDANTS BE PAROLED?

\begin{tabular}{|lcc|}
\hline RESPONSE & $\begin{array}{c}\text { SAMPLE } \\
\text { PERCENT }\end{array}$ & $\begin{array}{l}\text { POPULATION } \\
\text { RANGE P } \leq .05\end{array}$ \\
\hline MANSON & & \\
\hline Never Release & 70 & $55.39-82.13$ \\
Strongly Oppose Release & 27 & $15.45-41.40$ \\
Mildly Oppose Release & 1 & $.02-8.88$ \\
Indifferent & 1 & $.02-8.88$ \\
& & \\
FOLLOWERS & 28 & $16.23-42.28$ \\
Never Release & 25 & $13.84-39.27$ \\
Strongly Oppose Release & 21 & $10.79-34.84$ \\
Mildly Oppose Release & 3 & $.27-12.19$ \\
Indifferent & 6 & $1.26-16.57$ \\
Mildly Favor Release & 1 & $.02-8.88$ \\
Strongly Favor Release &
\end{tabular}

TABLE III

WHAT SHOULD HAVE HAPPENED TO THE DEFENDANTS?

\begin{tabular}{|c|c|c|}
\hline RESPONSE & $\begin{array}{l}\text { SAMPLE } \\
\text { PERCENT }\end{array}$ & $\begin{array}{l}\text { POPULATION } \\
\text { RANGE } \mathrm{p} \leq .05\end{array}$ \\
\hline \multicolumn{3}{|l|}{ MANSON } \\
\hline Death Sentence & 64 & $49.20-77.07$ \\
\hline Life Sentence & 22 & $11.54-35.95$ \\
\hline Prison & 10 & $3.32-21.82$ \\
\hline Therapy & 10 & $3.32-21.82$ \\
\hline Institutionalized & 6 & $1.26-16.57$ \\
\hline \multicolumn{3}{|l|}{ FOLLOWERS } \\
\hline Death Sentence & 39 & $25.54-53.82$ \\
\hline Life Sentence & 25 & $13.84-39.27$ \\
\hline Prison & 16 & $7.17-29.12$ \\
\hline Therapy & 19 & $9.31-32.58$ \\
\hline Institutionalized & 10 & $3.32-21.82$ \\
\hline
\end{tabular}


Once again this difference appears when subjects are asked whether Charles Manson was crazy and whether his associates were crazy. $78 \%$ of the subjects indicated thay they thought Charles Manson was crazy, while $45 \%$ of the subjects indicated that they thought his associates were crazy. $8 \%$ of the subjects thought that Manson was not crazy, while $18 \%$ of the subjects said that his associates were not crazy. $14 \%$ of the subjects were unsure whether Manson was crazy, while $37 \%$ of the subjects were unsure whether his associates were crazy.

When asked how this case effects their feelings of safety, subjects were divided as follows: unsafe $(10 \%)$, much less safe $(15 \%)$, a little less safe $(42 \%)$, no effect $(30 \%)$, and a little more safe (1\%). A Kruskal-Wallis H-test revealed no significant difference between the age groups and a Mann-Whitney U-test revealed no significant sex difference.

It was felt that if subjects felt that the likelihood of this sort of event recurring was high, they would also report that their feelings of safety were negatively effected by this case. In fact, this was not the case. While the subjects tended to report little or no negative effect on their feelings of safety, they also tended to report that they felt it was likely that such an event would recur. $15 \%$ of the subjects said that it definitely would happen again, $36 \%$ said that it was very likely, $36 \%$ said it was somewhat 
likely, $7 \%$ said that it was somewhat unlikely that it would happen again, and $4 \%$ said that it was very unlikely that it would happen again.

The Kruskal-Wallis H-test showed a significant difference between the age groups with regard to the likelihood of recurrence $(H=11.72, p<.01)$. To determine the nature of that difference, a series of Mann-Whitney U-tests were done. Subjects under twenty-four years of age thought it was less likely that such a crime would happen again than subjects from twenty-four to thirty years of age $(U=-3.24$, $p<.00069)$. Subjects under twenty-four years of age were also found to feel that it was less likely that such a crime would happen again than subjects who were thirty years of age or over $(U=-1.62, p<.05)$. A Mann-Whitney U-test revealed no significant sex difference with regard to the. likelihood of this sort of crime happening again.

Subjects were asked whether they would classify the Manson case as a senseless crime or as an understandable murder. $90 \%$ of the subjects stated that it was a senseless crime, while $7 \%$ of the subjects stated that it was understandable. $3 \%$ gave no answer.

Subjects were asked to rate the Manson case on a scale from 1 to 10 on horribleness, and on a scale from 1 to 10 on bizarreness, with 10 being either most horrible or most bizarre. The mean rating for horribleness was 9.48. The mean rating for bizarreness was 9.02 . 
TABLE IV

RATINGS ON HORRIBLENESS AND BIZARRENESS

\begin{tabular}{|c|c|c|}
\hline RAT ING & $\begin{array}{l}\text { SAMPLE } \\
\text { PERCENT }\end{array}$ & $\begin{array}{l}\text { POPULATION } \\
\text { RANGE } \mathrm{P} \leq .05\end{array}$ \\
\hline \multicolumn{3}{|l|}{ HORR I BLENESS } \\
\hline 10 & 69 & $56.46-82.94$ \\
\hline 9 & 12 & $4.54-24.31$ \\
\hline 8 & 10 & $3.32-21.82$ \\
\hline & 6 & $1.26-16.57$ \\
\hline No Answer & 3 & $.27-12.19$ \\
\hline \multicolumn{3}{|l|}{ BIZARRENESS } \\
\hline 10 & 49 & $34.61-63.52$ \\
\hline 9 & 12 & $4.54-24.31$ \\
\hline 8 & 16 & $7.17-29.12$ \\
\hline 7 & 9 & $2.78-20.54$ \\
\hline 6 & 4 & $.49-13.72$ \\
\hline No Answer & 9 & $2.78-20.54$ \\
\hline
\end{tabular}

Finally, subjects were asked what is the single most frightening thing about this event? Of the fifteen responses which were reported by at least five percent of the subjects, only four were truly case-specific. These were: someone can control people/get people to kill (18\%), a pregnant victim $(9 \%)$, weak/vulnerable followers $(7 \%)$, and Manson or his followers could be paroled $(6 \%)$. Responses which were not case-specific are representative of responses to the same question with reference to other cases in the comparable cases survey. This indicates that the subjects tended to feel the same about the Manson case as they feel about other such cases. 
TABLE V

SINGLE MOST FRIGHTENING THING ABOUT THE CASE

\begin{tabular}{|lcl|}
\hline & $\begin{array}{c}\text { SAMPLE } \\
\text { PESPONSE }\end{array}$ & $\begin{array}{l}\text { POPULATION } \\
\text { RANGE P } \leq .05\end{array}$ \\
\hline Someone Can Control/Get & & \\
People to Kill & 18 & $8.58-31.44$ \\
Randomess & 16 & $7.17-29.12$ \\
ICould Be Victim & 13 & $5.18-27.03$ \\
People That Crazy Exist & 10 & $3.32-21.82$ \\
Pregnant Victim & 9 & $2.78-20.54$ \\
No Motive & 7 & $1.74-17.91$ \\
Weak/Vulnerable Followers & 7 & $1.74-17.91$ \\
Society That Breeds it & 7 & $1.74-17.91$ \\
No Value of Human Life & 7 & $1.74-17.91$ \\
Will/Could Happen Again & 7 & $1.74-17.91$ \\
Nature of Crime/Brutality & 7 & $1.26-16.57$ \\
No Remorse/No Guilt & 6 & $1.26-16.57$ \\
Laws Aren't Tough Enough & 6 & $1.26-16.57$ \\
Manson/Followers May Be & 6 & \\
Paroled Hagnened & 6 & \\
That it Happened & & \\
\hline
\end{tabular}

The Mass Murder Survey

A complete summary of the results of this survey can be found in Appendix $G$.

Section I. Mass murderers who were identified by at least ten percent of the subjects comprise a veritable who's who of mass murder. At the head of this list is Charles Manson. Most of these questionnaires were administered days after the shooting in the McDonalds in Southern California by Huberty, which accounts for the prominence of that case in this sample. Two of the comparable cases were mentioned by subjects: Dean Cor $11(2 \%)$, and Zebra (1\%) 
MASS MURDERERS IDENTIFIED BY AT LEAST

TEN PERCENT OF THE SUBJECTS

\begin{tabular}{|lll|}
\hline & SAMPLE & POPULATION \\
MASS MURDERER & RERCENT & $36.48-65.39$ \\
\hline Charles Manson & 51 & $31.88-60.67$ \\
Green River Killer & 46 & $23.80-51.81$ \\
McDonalds Shooting/Huberty & 37 & $17.06-43.54$ \\
I-5 Killer & 29 & $16.23-42.48$ \\
Jonestown & 28 & $13.84-39.27$ \\
Atlanta Child Murders & 25 & $8.58-31.44$ \\
Nazl Germany & 18 & $8.58-31.44$ \\
Richard Speck & 18 & $7.17-29.12$ \\
Son of Sam & 16 & $6.50-27.94$ \\
Hillside Strangler & 15 & $5.18-27.03$ \\
John Wayne Gacy & 13 & $4.54-24.31$ \\
Ted Bundy & 12 & $3.93-23.06$ \\
Jack the Ripper & 11 & $3.32-21.82$ \\
Seattle Chinatown Massacre & 10 & \\
\hline
\end{tabular}

Section II. Subjects were asked how many victims must be killed at one time for it to be mass murder, and how many times must the same person kill before it is mass murder. The mean number of victims before it is mass murder was 3.11 . The mean number of times the same person must murder before it is mass murder was 2.90. This estimate is low when compared to the actual murder cases which were most often identified. Of the classic mass murderers cited, James Huberty left twenty-one dead and nineteen wounded, Richard speck killed eight people, and in the Manson case seven people were killed over the course of two nights. In terms of the serial murderers most frequently mentioned here, the Green 
River Killer is estimated to have over twenty victims, Ted Bundy is estimated to have over forty victims (although he was only tried for a few of these murders), John Wayne Gacy was responsible for the murders of at least thirty-three boys, and Jack the Ripper killed five women. However, cases involving less victims were also reported, but to a lesser degree. A Kruskal-Wallis H-test showed no significant difference between the age groups. A mann-Whitney U-test revealed no significant sex difference. This was the finding for both the number of victims and the number of times a murderer must kill before it is generally considered to be mass murder.

When the Murderer is Related to the Victims. $90 \%$ of the subjects indicated that they thought the killing of a number of people under this condition was mass murder.

A Kruskal-Wallis $H$-test revealed no significant difference between the age groups. A test for the significance of differences between two proportions (Bruning \& Kintz, 1968), revealed a significant sex difference $(z=2.00, p<.04)$. Males saw the murder of a number of people, when the murderer is related to the victims, as mass murder more frequently than females.

$63 \%$ of the subjects indicated that they feel that such murderers are crazy, $6 \%$ said that they are not crazy, and $28 \%$ said that they were unsure. $3 \%$ gave no answer.

$79 \%$ of the subjects indicated that this sort of murder 
is senseless. A series of tests for the significance of differences between two proportions revealed no sex difference, but those thirty years of age and over indicated that they thought this sort of murder is senseless less often than those under twenty-four $(z=11.15, p<.001)$.

$16 \%$ of the subjects indicated that this sort of case has no effect on their feelings of safety, while $56 \%$ said they felt a little less safe, $13 \%$ said they felt much less safe and $13 \%$ said they felt unsafe. $1 \%$ gave no answer. A series of Mann-Whitney U-tests revealed no significant difference between the age groups. A significant difference was found between the sexes, with females indicating they felt less safe than males $(z=2.65, p<.01)$.

When the Murderer kills Repeatedly in the Course of Armed Robbery. $69 \%$ of the subjects reported that they felt this sort of murder is mass murder, while $15 \%$ indicated that it was not. $1 \%$ gave no answer and $17 \%$ said that it was sometimes. A series of tests for the significance of difference between two proportions revealed no significant difference between the age groups. Females indicated that they thought this sort of murder was mass murder more frequently than males $(z=2.00, p<.04)$.

$54 \%$ of the subjects reported that they thought such murderers were crazy. $16 \%$ said that they were not and $27 \%$ were unsure. $3 \%$ gave no answer.

$82 \%$ of the subjects said that they thought this sort 
of murder was senseless, while $15 \%$ said that they did not. $3 \%$ gave no answer. A test for significance of difference between two proportions revealed no significant sex difference. Subjects under twenty-four years of age saw it as senseless more often than subjects who were thirty years of age or older $(z=2.80, p<.01)$.

$15 \%$ of the subjects reported that such cases have no effect on their feelings of safety. $57 \%$ indicated that they felt a little less safe, $17 \%$ said that they felt much less safe, and $10 \%$ said that they felt unsafe. $1 \%$ gave no answer. A series of Mann-Whitney $U$-tests revealed no significant difference between the age groups. Females reported that they felt less safe $(z=2.40, p<.01)$.

\section{When the Murderer Kills Repeatedly in the course of}

Rape. $88 \%$ of the subjects reported that they felt this sort of murder is mass murder, while $7 \%$ said that it is not. $1 \%$ gave no answer, and $4 \%$ said that it is sometimes. A series of tests for the significance of difference between two proportions revealed no significant difference between the age groups. Females reported that it is mass murder more often than males $(z=2.33, p<.02)$.

$75 \%$ of the subjects reported that they thought such murderers are crazy. $6 \%$ said that they are not and $15 \%$ were unsure. $1 \%$ gave no answer.

$82 \%$ of the subjects said that this sort of murder is senseless, while $12 \%$ said that it is not. $6 \%$ gave no answer. 
A test for the significance of difference between two proportions revealed a significant difference for age. Those. twenty-four years of age saw it as senseless more frequently than those thirty years of age and older $(z=2.8, p<.01)$.

$17 \%$ of the subjects indicated that this sort of case has no effect on their feelings of safety, while $33 \%$ said they felt a little less safe, $24 \%$ said they felt much less safe and $26 \%$ said they felt unsafe. $1 \%$ gave no answer. A series of Mann-Whitney U-tests revealed no significant difference between the age groups. Females reported feeling less safe $(z=4.52, p<.001)$.

When Military Personnel are Killed During a War. $58 \%$ of the subjects said they felt this sort of murder is mass murder, while $24 \%$ said that it is not. $1 \%$ gave no answer and $17 \%$ said that it is mass murder sometimes. A series of tests for the significance of difference between two proportions revealed no difference between the age groups. Females saw it as mass murder more often $(z=3.92, p<.001)$.

$27 \%$ of the subjects reported that they thought such murderers are crazy, while $39 \%$ said that they are not. $31 \%$ were unsure and $2 \%$ gave no answer.

$60 \%$ of the subjects reported that they felt this sort of murder is senseless. $35 \%$ said that it is not. $6 \%$ gave no answer. A test for the significance of difference between two proportions revealed no significant difference between the age groups and no significant sex difference. 
$33 \%$ of the subjects indicated that this sort of case has no effect on their feelings of safety, while $42 \%$ said they felt a little less safe, $10 \%$ said they felt much less safe and $12 \%$ said they felt unsafe. $3 \%$ gave no answer. A series of Mann-Whitney $U$-tests revealed no significant sex difference and no significant difference between the age groups.

When Civilians are Killed During a War. $78 \%$ of the subjects reported that they thought such murder is mass murder, while $9 \%$ said that they did not. $1 \%$ gave no answer and $12 \%$ said that it is sometimes. A test for the significance of difference between two proportions revealed no significant difference between the age groups. Females felt that it is mass murder more often $(z=3.25, p<.001)$.

$42 \%$ of the subjects reported that they thought this sort of murderer is crazy, while $27 \%$ said that this sort of murderer is not. $29 \%$ were unsure and $2 \%$ gave no answer.

$83 \%$ of the subjects reported that they felt this sort of murder is senseless, while $13 \%$ said that it is not. $3 \%$ gave no answer. A series of tests for the significance of difference between two proportions revealed no sex difference and no significant difference between the age groups.

$18 \%$ of the subjects indicated that this sort of case has no effect on their feelings of safety, while $37 \%$ said they felt a little less safe, $28 \%$ said they felt much less safe and $16 \%$ said they felt unsafe. A series of Mann-Whitney 
U-tests revealed no significant difference between the age groups. Females reported that they felt less safe than males $(z=2.14, p<.02)$.

When Military Personnel are Killed Not at War. $88 \%$ of the subjects reported that they thought this sort of murder is mass murder, while $1 \%$ said that it is not. $2 \%$ gave no answer and $9 \%$ said that it is sometimes. A series of tests for the significance of difference between two proportions revealed no significant sex difference and no significant difference between the age groups.

$63 \%$ of the subjects reported that they thought such murderers are crazy, while $11 \%$ said that they are not. $22 \%$ were unsure and $2 \%$ gave no answer.

$90 \%$ of the subjects reported that they thought this sort of murder is senseless, while $7 \%$ said they did not. $3 \%$ gave no answer. A series of tests for the significance of difference between two proportions revealed no significant sex difference and no significant difference between the age groups.

$28 \%$ of the subjects reported that this sort of case has no effect on their feelings of safety, while $34 \%$ said they felt a little less safe, $26 \%$ said they felt much less safe and $11 \%$ said they felt unsafe. $1 \%$ gave no answer. A series of Mann-Whitney U-tests revealed no significant difference between the age groups and no significant sex difference. 
When Civilians are Killed Not at War. $96 \%$ of the subjects reported that they felt this sort of murder is mass murder, while $0 \%$ said it is not. $1 \%$ gave no answer and $3 \%$ said it is mass murder sometimes. A series of tests for the significance of difference between two proportions revealed no significant difference between the age groups and no significant sex difference.

$66 \%$ of the subjects reported that they thought such murderers are crazy, while $15 \%$ said that they did not. $17 \%$ said that they were unsure and $2 \%$ gave no answer.

$92 \%$ of the subjects indicated that they thought this sort of murder is senseless, while $6 \%$ said that it is not. $2 \%$ gave no answer. A series of tests for the significance of difference between two proportions revealed no significant sex difference and no significant difference between the age groups.

$13 \%$ of the subjects reported that this sort of case has no effect on their feelings of safety, while $37 \%$ said they felt a little less safe, $24 \%$ said they felt much less safe and $25 \%$ said they felt unsafe. $1 \%$ gave no answer. A series of Mann-Whitney U-tests revealed no significant difference between the age groups and no significant sex difference.

\section{When Murders are Committed by Organized Criminals.}

$98 \%$ of the subjects reported that they thought this sort of murder is mass murder, while $0 \%$ said that it is not. $1 \%$ 
said it is sometimes and $1 \%$ gave no answer. A series of tests for the significance of difference between two proportions revealed no significant sex difference and no significant difference between the age groups.

$51 \%$ of the subjects reported that they thought such murderers are crazy, while $21 \%$ said they are not. $26 \%$ were unsure and $2 \%$ gave no answer.

$83 \%$ of the subjects indicated that they thought such murders are senseless, while $11 \%$ said they are not. $6 \%$ gave no answer. A series of tests for the significance of difference between two proportions revealed no significant sex difference and no significant difference between the age groups.

$21 \%$ of the subjects reported that this sort of case has no effect on their feelings of safety, while $40 \%$ said they felt a little less safe, $18 \%$ said they felt much less safe, and $19 \%$ said they felt unsafe. $1 \%$ gave no answer. A series of Mann-Whitney U-tests revealed no significant sex difference and no significant difference between the age groups.

When Murders are Committed by Terrorists. $96 \%$ of the subjects reported that they thought this sort of murder is mass murder, while $1 \%$ said that it is not. $2 \%$ said it is sometimes and $1 \%$ gave no answer. A series of tests for the significance of difference between two proportions revealed no significant difference between the age groups. Females 
thought it to be mass murder more frequently than males $(z=2.00, p<.05)$.

$55 \%$ of the subjects indicated that they thought such murderers are crazy, while $18 \%$ said they are not. $25 \%$ were unsure and $2 \%$ gave no answer.

$82 \%$ of the subjects reported that they thought this sort of murder is senseless, while $11 \%$ said it is not. A series of tests for the significance of difference between two proportions revealed no sex difference and no significant difference between the age groups.

$19 \%$ of the subjects reported that this sort of case has no effect on their feelings of safety, while $42 \%$ said they felt a little less safe, $18 \%$ said they felt much less safe and $20 \%$ said they felt unsafe. $1 \%$ gave no answer. A series of Mann-Whitney U-tests revealed no significant sex difference. Those thirty years of age and over felt less safe than those twenty-four to thirty years of age $(z=2.00, p<.05)$.

When Murders are the Result of Gang Conflicts. $70 \%$ of the subjects reported that they thought this sort of murder is mass murder, while $24 \%$ said that it is not. $6 \%$ said that it is sometimes, and $1 \%$ gave no answer. A series of tests for the significance of difference between two proportions revealed no significant difference between the age groups. Females saw it as mass murder more frequently than males $(z=2.09, p<.05)$. 
$39 \%$ of the subjects reported that they thought such murderers are crazy, while $26 \%$ said they are not. $33 \%$ were unsure and $2 \%$ gave no answer.

$88 \%$ of the subjects indicated that they thought this sort of murder is senseless, while $10 \%$ said it is not. $2 \%$ gave no answer. A series of tests for the significance of difference between two proportions revealed no significant sex difference. Those thirty years of age and over saw it as less senseless than those under twenty-four years of age $(z=2.00, p<.05)$.

$26 \%$ of the subjects reported that this sort of case has no effect on their feelings of safety, while $49 \%$ said they felt a little less safe, $8 \%$ said they felt much less safe and $16 \%$ said they felt unsafe. $1 \%$ gave no answer. A series of Mann-Whitney U-tests revealed no significant difference between the age groups. Females indicated they felt less safe than males $(z=2.27, p<.02)$.

When the Murderer is a Hired Killer. $97 \%$ of the subjects reported that they thought this sort of murder is mass murder, while $1 \%$ said that they did not. $1 \%$ said that it is sometimes, and $1 \%$ gave no answer. A series of tests for the significance of difference between two proportions revealed no significant sex difference and no significant difference between the age groups.

$54 \%$ of the subjects reported that they thought such murderers are crazy, while $24 \%$ said that they are not. $20 \%$ 
were unsure and $2 \%$ gave no answer.

$82 \%$ of the subjects reported that this sort of murder is senseless, while $16 \%$ said it is not. $2 \%$ gave no answer. A series of tests for the significance of difference between two proportions revealed no significant sex difference and no significant difference between the age groups.

$27 \%$ of the subjects reported that this sort of case has no effect on their feelings of safety, while $40 \%$ said they felt a little less safe, $16 \%$ said they felt much less safe and $16 \%$ said they felt unsafe. $1 \%$ gave no answer. A series of Mann-Whitney U-tests revealed no significant difference between the age groups. Females felt less safe than males $(z=2.71, p<.01)$.

Summary. Under all conditions where a number of people might be killed, over $50 \%$ of the subjects stated that it was mass murder. The range was $58 \%$ to $98 \%$. This is borne out in the cases identified by these subjects as mass murder. The only exception was a hired killer, none of the mass murderers who were identified by subjects were hired killers. But then how successful would a famous hired killer be? All categories were seen as senseless over $50 \%$ of the time. The range was $60 \%$ to $92 \%$. When asked if such murderers are crazy, three categories fell under the 50\% mark: military personnel killed at war (27\%), civilians killed at war (42\%), and when killing is the result of a gang conflict $(42 \%)$.

Females were more likely to identify these murders as 
mass murder and were more likely to report a negative effect on their feelings of safety. Subjects thirty years of age or older were less likely to identify a type of murder as senseless.

The Recognition Poll

A complete summary of the results of this instrument can be found in Appendix $H$.

\section{TABLE VII}

ITEMS WHICH FALL IN THE CONFIDENCE INTERVAL WITH CHARLES MANSON

\section{ITEM}

PERCENTAGE

Johnny Carson

Billie Jean King

96

Watergate

96

Mel Brooks

94

Vidal Sassoon

91

Arnold Palmer

91

Bruce Lee

89

Anwar Sadat

89

Charles Manson

87

Janis Joplin

87

Henry Mancini

86

Hubert Humphrey

77

72

Charles Manson was identified by $87 \%$ of the subjects. Using the test for the significance of difference between two proportions (Bruning \& Kintz, 1968), a confidence interval was established for this proportion. Given forty-seven subjects, this confidence interval is from $97 \%$ through $72 \%$ 
$(p<.05)$. A look at the items which fall in this range is instructive; a measure of the degree of fame which charles. Manson and the murders for which he is known have attained.

All of the principals in the Manson case were identified to varying degrees. Charles Manson (87\%), Sharon Tate $(62 \%)$, Rosemary Labianca $(19 \%)$, Leno Labianca (15\%), Leslie Van Houten $(6 \%)$, Susan Atkins $(6 \%)$, Charles Watson $(6 \%)$, Abigail Folger (6\%), Jay Sebring (4\%), Patricia Krenwinkle $(4 \%)$, Voytek Frykowski $(4 \%)$, and Steven Parent $(2 \%)$. Only two of the twenty six items which were related to the twelve comparable cases were identified, these were: Sal Mineo (2\%) and Zebra $(2 \%)$.

\section{The Comparable Cases}

A complete summary of the results from both the single case form and the multiple case form of this survey can be found in Appendix E.

The single cases. $5 \%$ of the subjects were able to correctly identify the case they received. This breaks down to $8 \%$ of the subjects who received the Sal Mineo case and $62 \%$ of the subjects who received the Manson case. None of the other cases were correctly identified. A test for the significance of difference between two proportions revealed a significant difference between the the proportion of subjects who identified the Sal Mineo case and the Manson case $(z=3.00, p<.002)$. 
When asked why the murder happened, $39 \%$ of the subjects indicated that they thought it happened because the murderer was crazy. This was also the predominant response when subjects were asked this question with regard to the Manson case, in the Manson survey.

$52 \%$ of the subjects said that the murderer should never be paroled, while $32 \%$ said they strongly opposed parole, $8 \%$ said they mildly opposed parole, $5 \%$ said they were indifferent and $1 \%$ said they mildly favored parole. $1 \%$ gave no answer. A Kruskal-Wallis H-test revealed no significant difference between the cases. A series of Mann-Whitney Utests revealed significant sex differences, In all cases where a significant sex difference existed, females were more opposed to parole than males: 01ive $(U=3.50$. $p<.05)$, Manson $(U=8.00, p<.04)$, and Mineo $(U=7.50$, $p<.05)$

When asked why they felt as they did about parole, $30 \%$ of the subjects said the murderer was dangerous and might repeat, $13 \%$ said they should not be in society, and $10 \%$ said they should pay for their crime.

When asked what should have happened to the murderer, $46 \%$ of the subjects said they should have received the death penalty, while $26 \%$ said they should have received life sentences, $16 \%$ said they should have gone to prison and $15 \%$ said they should receive therapy. These responses are comparable to responses to this question on the Manson survey. 
$45 \%$ of the subjects said they thought that the murderer was crazy, $16 \%$ said the murderer was not crazy, and $35 \%$ were unsure. $3 \%$ gave no answer.

$55 \%$ of the subjects reported that the case had no effect on their feelings of safety, while $30 \%$ said they felt a little less safe, $6 \%$ said they felt much less safe and $6 \%$ said they felt unsafe. $2 \%$ gave no answer. A Kruskal-Wallis $H$-test revealed no significant differences among the cases. A series of Mann-Whitney U-tests showed a significant sex difference with regard to the Smith case. Females felt less safe $(U=4.00, p<.04)$.

When asked why they answered as they did, $12 \%$ of the subjects cited the randomness of such events, $11 \%$ felt they could control it or avoid it, $10 \%$ said they realized such things happen and accept this as fact, and $9 \%$ said why worry it happens.

$5 \%$ of the subjects indicated that they thought that it was very unlikely that such a murder would happen again, while $11 \%$ said it was somewhat unlikely, $29 \%$ said that it was somewhat $1 i k e l y, 38 \%$ said that it was very 1 ikely and $16 \%$ said that it definitely would happen again. $1 \%$ gave no answer. A Kruskal-Wallis H-test revealed no significant difference among the cases. A series of Mann-Whitney U-tests revealed a sex difference with regard to the Manson case. Males felt that it was more likely to happen again than females $(U=9.00, p<.05)$. 
When asked why they answered as they did, $26 \%$ of the subjects said that there are a lot of crazy people in the world, $20 \%$ said that similar crimes happen, $9 \%$ said that we have a society that breeds it and $5 \%$ cited media violence.

$74 \%$ of the subjects reported that they thought the murder was senseless, while $14 \%$ said that it was not. $13 \%$ gave no answer.

When asked why they answered as they did, $39 \%$ of the subjects said thare was no reason or motive for the murder, $14 \%$ said that murder is senseless and $6 \%$ said that the murderer was crazy.

Subjects were asked to rank the murder on a scale of 1 to 10 on horribleness, with 10 being most horrible. $36 \%$ of the subjects ranked their case at $10,18 \%$ ranked their case at $9,20 \%$ ranked their case at $8,6 \%$ ranked their case at 7 , $5 \%$ ranked their case at $6,7 \%$ ranked their case at 5 , and $1 \%$ ranked their case at $2.7 \%$ gave no answer. A Kruskal-Wallis $H$-test revealed no siginificant differences among the cases. A series of Mann-Whitney U-tests revealed a significant sex difference. Females saw the cases as more horrible than males when a sex difference existed: 01 ive $(U=3.00$, $p<.03)$, Manson $(U=5.00, p<.02)$, and Mineo $(U=1.50$, $p<.05)$. The mean ranking for horribleness was 8.51 . Subjects were asked to rank the murder on a scale of 1 to 10 on bizarreness, with 10 being most bizarre. $23 \%$ of the subjects ranked their case at $10,10 \%$ ranked their case 
at $9,19 \%$ ranked their case at $8,11 \%$ ranked their case at $7,5 \%$ ranked their case at $6,8 \%$ ranked their case at $5,3 \%$ ranked their case at $4,2 \%$ ranked their case at $3,4 \%$ ranked their case at 2 , and $1 \%$ ranked their case at 1 . $15 \%$ gave no answer. A Kruskal-Wallis H-test revealed significant differences among the cases $(H=29.24, p<.01)$. A series of Mann-Whitney U-tests were done to compare all other cases to the Manson case. When a difference existed, other cases were seen as less bizarre than the Manson case: the Alday family murder $(U=15, p<.002)$, Cowan $(U=2, p<.02)$, and Mineo $(U=15, p<.002)$. A series of Mann-Whitney $U$ tests revealed a sex difference. When a sex difference existed, females saw the other case as less bizarre than the Manson case: Frazier $(U=4.5, p<.05)$, Cowan $(U=4.5$, $p<.05)$, and Mineo $(U=1, p<.02)$. The mean ranking for bizarreness was 7.60 .

Subjects were asked what the single most frightening thing was about the murder case. Their responses were not very case-specific for the most part. $20 \%$ of the subjects said that randomness was the single most frightening thing, $10 \%$ said that people like that exist, $10 \%$ said that they or someone they care about could be a victim, and $10 \%$ said how could they do such a thing?

The Multiple Cases. $6 \%$ of the subjects were able to identify a case. This breaks down to $5 \%$ of the subjects identifying the Sal Mineo case and $65 \%$ of the subjects 
identifying the Manson case. None of the other cases were correctly identified. A test for the significance of difference between two proportions revealed a significant difference between the proportion of subjects identifying the Manson case and the Mineo case $(z=3.67, p<.001)$.

When asked why the murder happened, again the most frequent answer was that the murderer was crazy $(37 \%)$, this was followed by drugs and alcohol (10\%), release of frustration and anger $(10 \%)$, a mission or a cause $(7 \%)$, and pressure from a leader $(6 \%)$.

$52 \%$ of the subjects said that the murderer should never be paroled, while $32 \%$ strongly opposed parole, $9 \%$ mildly opposed parole, $3 \%$ were indifferent and $3 \%$ mildly favored parole. 1\% gave no answer. A Friedman test for related samples revealed no differences among the cases. A series of Mann-Whitney $U$-tests showed no significant sex differences.

When asked why they felt as they did about parole, $23 \%$ of the subjects said the murderer was dangerous and might repeat, $17 \%$ said that the murderer was crazy, $16 \%$ said that they could not be reformed, and $7 \%$ said that they had committed murder.

When asked what should have happened to the murderer, $39 \%$ of the subjects said they should have received the death penalty, while $28 \%$ said they should have gone to prison, $23 \%$ said they should have received life sentences, and $18 \%$ said 
they should have received therapy.

$60 \%$ of the subjects said that they thought the murderer was crazy, while $23 \%$ said they did not. $16 \%$ were unsure and $1 \%$ gave no answer.

$53 \%$ of the subjects reported that the case had no effect on their feelings of safety, while $30 \%$ said they felt a little less safe, $13 \%$ said they felt much less safe and $4 \%$ said they felt unsafe. $1 \%$ said they felt very safe. A Friedman test for related samples revealed a significant difference among the cases $(F=44.35, p<.001)$. A series of Wilcoxon sign rank tests were done to compare the Manson case to the other cases. When a difference existed, subjects said the Manson case made them feel less safe: Corll $(p<.05)$, Armistead $(p<.05)$, 01 ive $(p<.01)$, Baniszewski $(p<.01)$, and Beam $(p<.02)$. A series of Mann-Whitney $U-$ tests revealed no significant sex differences.

When asked why they felt as they did, subjects said they could avoid it or control it $(21 \%)$, $12 \%$ said that it was a random event, $7 \%$ said that it was not a common event, $7 \%$ said that they or someone they care about could be a victim and $4 \%$ said why worry, it happens.

$1 \%$ of the subjects said that such a crime would never happen again, while $5 \%$ said it was very unlikely, $13 \%$ said it was somewhat unlikely, $43 \%$ said it was somewhat likely, $32 \%$ said it was very likely and $8 \%$ said that it definitely would happen again. A Friedman test for related samples 
revealed no significant differences among the cases. A series of Mann-Whitney U-tests revealed no significant sex differences.

When asked why they answered as they did, $14 \%$ said that similar crimes happen, $8 \%$ said there are a lot of crazy people in the world, $7 \%$ said there is no defense against it, $7 \%$ said it is not a common event and $5 \%$ said that other people like that exist.

$85 \%$ of the subjects reported that they thought the murder was senseless, while $13 \%$ said it was not. $1 \%$ gave no answer.

When asked why they answered as they did, $26 \%$ of the subjects said that there was no reason or motive for the murder, $7 \%$ said that murder is senseless and $7 \%$ said that the murderer was crazy.

Subjects were asked to rank the murder on a scale of 1 to 10 on horribleness, with 10 being most horrible. $28 \%$ ranked the murder at $10,19 \%$ ranked the murder at $9,20 \%$ ranked the murder at $8,15 \%$ ranked the murder at $7,7 \%$ ranked the murder at $6,5 \%$ ranked the murder at $5,3 \%$ ranked the murder at $4,1 \%$ ranked the murder at $3,1 \%$ ranked the murder at 2 and $1 \%$ ranked the murder at 1 . $1 \%$ gave no answer. A Friedman test for related samples revealed no significant difference among the cases. A series of Mann-Whitney Utests revealed no significant sex difference. The mean ranking for horribleness was 8.09 . 
Subjects were asked to rank the murder on a scale of 1 to 10 , with 10 being most bizarre. $23 \%$ of the subjects ranked the murder at $10,10 \%$ ranked the murder at $9,13 \%$ ranked the murder at $8,15 \%$ ranked the murder at $7,11 \%$ ranked the murder at $6,12 \%$ ranked the murder at $5,5 \%$ ranked the murder at $4,2 \%$ ranked the murder at $3,3 \%$ ranked the murder at 2 , and $1 \%$ ranked the murder at $1.4 \%$ gave no answer. A Friedman test for related samples revealed a significant difference between the cases $(F=73.68, p<.001)$. A series of Wilcoxon sign rank tests were done. When a difference existed between the Manson case and the other cases, the Manson case was seen as more bizarre: Mineo $(p<.01)$, Frazier $(p<.01)$, the Alday family murder $(p<.01)$, Cowan $(p<.01)$ and Steelman and Gretzler $(p<.05)$. A series of Mann-Whitney U-tests revealed no significant sex differences. The mean ranking for bizarreness was 7.17 .

When asked what the single most frightening thing about the case was, $7 \%$ said that no one stopped it, $7 \%$ said weak people who follow, $6 \%$ said randomness and $5 \%$ said no remorse or guilt.

Subjects who were given all cases at one time were asked to rank them from one to thirteen on horribleness, with one being least horrible and thirteen being most horrible. Each case received a ranking from one to thirteen, and no two cases were to be given the same rank. In essence, they were ranking them in relation to each other. This is 


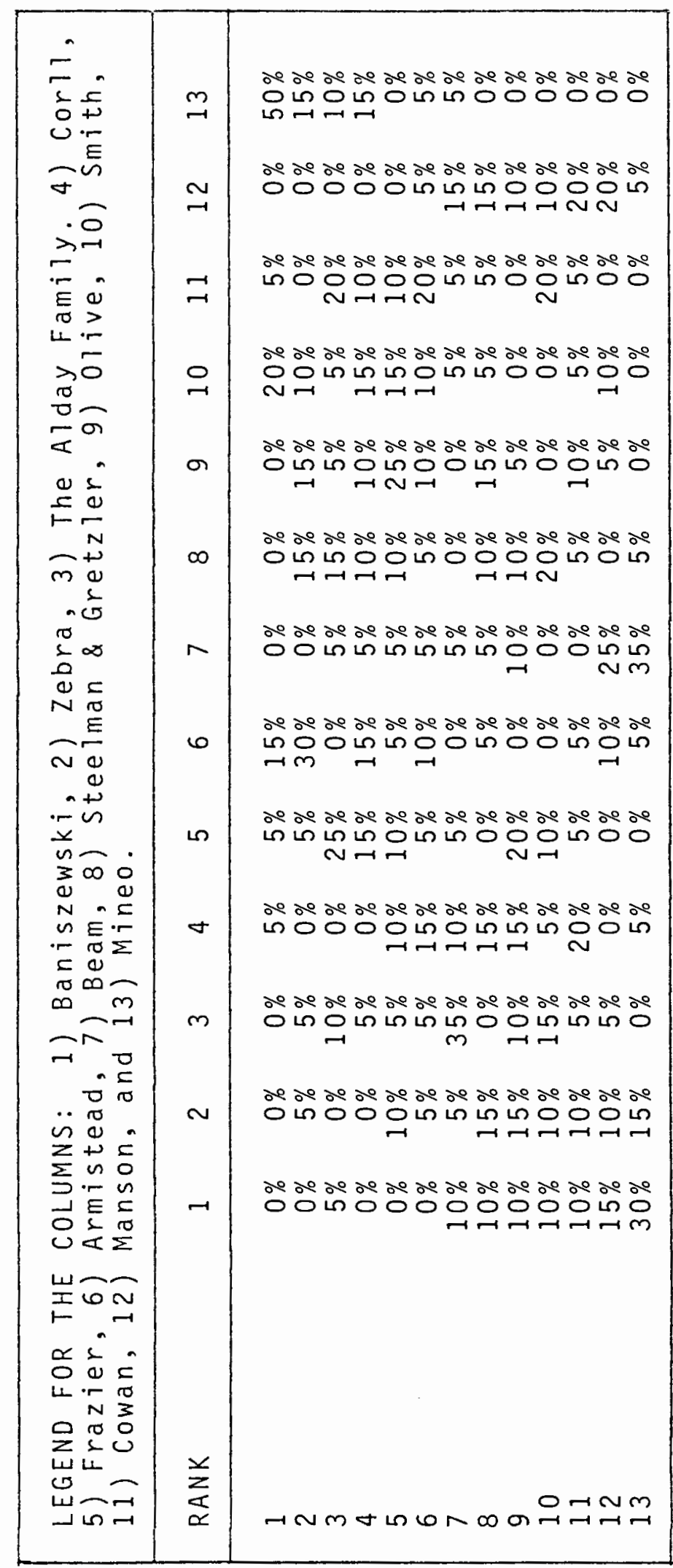


different from the earlier ranking on horribleness where the rank was in relation to a personal scale of horribleness. A Friedman test for related samples revealed a significant difference between the cases $(F=88.59, p<.001)$. A series of Wilcoxon sign rank tests were done. When a difference existed, the other case was seen as more horrible than the Manson case: the Alday family murder $(p<.02)$, Armistead $(p<.01)$, Steelman and Gretzler $(p<.01)$, 01 ive $(p<.01)$, Cowan $(p<.01)$, Smith $(p<.01)$, Frazier $(p<.01)$, and Mineo $(p<.01)$. There was no significant difference between the Manson case and: Beam, Baniszewski, Zebra, and Corl1. A series of Mann-Whitney U-tests revealed a sex difference in only one case, males saw the corll case as less horrible than females $(U=20.5, p<.05)$. It is difficult to know what these results mean since there was no significant differences either between the cases or sexes in the earlier ratings of horribleness.

The Manson Case. The results of questionnaires from the single form and the multiple form of the comparable cases which were about the Manson case were compared with results from the Manson survey.

A series of Kruskal-Wallis H-tests were done. These revealed no difference between the three surveys on feelings of safety, probability of recurrence and bizarreness. A significant difference was found with regard to horribleness $(H=7.54, p<.05)$. A series of Mann-Whitney U-tests 
revealed that the subjects from the multiple case form of the comparable cases saw the Manson case as more horrible than the subjects from the Manson survey $(z=2.21, p<.01)$.

The Media Coverage

A complete summary of the results from the content analysis can be found in Appendix I.

TABLE IX

CITATIONS OF COMPARABLE CASES

\begin{tabular}{|lcrr|}
\hline & YEARS & & \multirow{2}{*}{ NEW YORK } \\
CASE & ELAPSED & READER'S GUIDE & TIMES INDEX \\
\hline Baniszewski & 19 & 3 & 1 \\
Smith & 18 & 1 & 6 \\
Manson & 15 & 68 & 297 \\
Frazier & 14 & 2 & 20 \\
Zebra & 11 & 5 & 13 \\
Alday & 11 & 5 & 8 \\
Corli & 11 & 3 & 45 \\
Steelman & & & 7 \\
Gretzler & 11 & 0 & 4 \\
Armistead & 10 & 0 & 1 \\
Oiive & 9 & 0 & 0 \\
Beam & 8 & 5 & 1 \\
Mineo & 8 & 2 & 3 \\
Cowan & 7 & & \\
\hline
\end{tabular}

The difference between the coverage of the Manson case and the other cases is obvious. A chi-square test for all cases, for the citations in Reader's Guide was done. A chisquare value of 580.85 was found. This value was reduced to $435.94(p<.001)$ when the expected value was weighted for 
the number of years that had elapsed between the murder and 1984. A significant result was also found for a comparison of citations in The New York Times Index. A chi-square value of 2430.87 was found for these citations. This value was reduced to $1825.01(p<.001)$ when the expected value was weighted for the number of years elapsed between the murder and 1984 .

The magazine coverage tends to be more in depth and more analytical than the newspaper coverage. Magazine coverage also tends to draw more conclusions than newspaper coverage.

The newspaper coverage tends to follow the who, what, where and when format. Consequently, the categories which showed the highest degree of coverage by The New York Times tended to follow this format: Sharon Tate (81\%), Susan Atkins $(45 \%)$, Leslie Van Houten (44\%), Patricia Krenwinkle $(40 \%)$, California $(70 \%)$. When you compare these percentages to those garnered by more speculative categories, the difference is clear: Manson is unbalanced/crazy/sick $(2 \%)$, the crime was brutal/bloody/grotesque (13\%), the murder was a sign of the times $(2 \%)$, the followers worshipped Manson/were disciples $(5 \%)$, and the followers were formerly good/corrupted by Manson $(1 \%)$.

The factual information can also be found in magazines. The real difference 1 ies in information which is more speculative in nature: Manson is unbalanced/crazy/sick (27\%), 
the crime was brutal/bloody/grotesque $(60 \%)$, the murder was a sign of the times $(10 \%)$, the followers worshipped Manson/ were disciples (37\%), and the followers were formerly good/ corrupted by Manson $(18 \%)$.

\section{TABLE $X$}

MANSON'S IMAGE

\begin{tabular}{|c|c|c|c|c|}
\hline CATEGORY & $\begin{array}{l}\text { NEW } \\
\text { YORK }\end{array}$ & TIMES & $\begin{array}{l}\text { READER'S } \\
\text { GUIDE }\end{array}$ & $\begin{array}{l}\text { MANSON } \\
\text { SURVEY }\end{array}$ \\
\hline \multicolumn{5}{|l|}{ MANSON'S CHARACTER } \\
\hline Unbalanced/Crazy/Sick & & $2 \%$ & $27 \%$ & $43 \%$ \\
\hline Charismatic & & $5 \%$ & $17 \%$ & $21 \%$ \\
\hline Thought of as a Diety & & $6 \%$ & $28 \%$ & $22 \%$ \\
\hline No Remorse/Guilt & & $1 \%$ & $2 \%$ & $10 \%$ \\
\hline Antisocial & & $0 \%$ & $10 \%$ & $1 \%$ \\
\hline Dangerous/Violent & & $5 \%$ & $10 \%$ & $7 \%$ \\
\hline Musician/Poet & & $5 \%$ & $18 \%$ & $1 \%$ \\
\hline \multicolumn{5}{|l|}{ Thought of as Devil/Anti- } \\
\hline Christ & & $2 \%$ & $17 \%$ & $3 \%$ \\
\hline Mystical Patter/Philosophy & & $8 \%$ & $37 \%$ & $0 \%$ \\
\hline Con Man/Cagey & & $1 \%$ & $18 \%$ & $0 \%$ \\
\hline Threatened People & & $1 \%$ & $13 \%$ & $0 \%$ \\
\hline Rasputin-like & & $5 \%$ & $10 \%$ & $0 \%$ \\
\hline Interest in 0 ccult & & $0 \%$ & $10 \%$ & $0 \%$ \\
\hline Seen as a Martyr & & $1 \%$ & $13 \%$ & $0 \%$ \\
\hline Folkhero & & $2 \%$ & $10 \%$ & $0 \%$ \\
\hline Felt Persecuted & & $2 \%$ & $15 \%$ & $0 \%$ \\
\hline Racist & & $2 \%$ & $12 \%$ & $0 \%$ \\
\hline
\end{tabular}

This is not an exhaustive list of statements about Manson, other major categories such as Manson's relationship to his followers are not listed here (see Appendix I). This list does however indicate a progression of the image from the media to the popular image. Many of the specific aspects 
of the media image have dropped out of the popular image.

It seems as though a more generic image of crazy has replaced Rasputin-like with a mystical patter.

A series of chi-square tests were done. Significant differences were found in all cases. When the frequencies from The New York Times were compared to the frequencies from the magazine articles from Reader's Gujde, a chi-square value of 31.21 was found $(15 \mathrm{df}, \mathrm{p}<.01)$. When The New York Times was compared to the Manson survey, a chi-square value of 61.53 was found $(6 \mathrm{df}, \mathrm{p}<.001)$. When the Reader's Guide frequencies were compared to the frequencies from the Manson survey, a chi-square value of 67.20 was found ( $3 \mathrm{df}$, $p<.001)$

The tendency for specific aspects and facts to drop out of the popular image is even more clear in areas that are less closely related to Charles Manson personally.

The following is not a complete list of all of the items having to do with the followers (see Appendix $F$ and Appendix I). This 1 ist consists of items related to the followers which were most frequently mentioned by the subjects who answered the Manson survey, and some of the more glaring omissions. It seems interesting that the actual murderers have been deleted from the popular image of Charles Manson and the Tate-Labianca murder case. The only codefendant to be mentioned by a subject answering the Manson survey was Leslie Van Houten. The particular subject who 
mentioned Leslie Van Houten knew of her because his mother had worked as a housekeeper for Leslie Van Houten's mother. Not a source of information open to many.

TABLE XI

THE FOLLOWER'S IMAGE

\begin{tabular}{|c|c|c|c|}
\hline CATEGORY & $\begin{array}{l}\text { NEW } \\
\text { YORK TIMES }\end{array}$ & $\begin{array}{l}\text { READER'S } \\
\text { GUIDE }\end{array}$ & $\begin{array}{l}\text { MANSON } \\
\text { SURVEY }\end{array}$ \\
\hline \multicolumn{4}{|l|}{ FOLLOWERS } \\
\hline $\begin{array}{l}\text { A Following/A Group } \\
\text { Followers Would Do Anything }\end{array}$ & $60 \%$ & $92 \%$ & $37 \%$ \\
\hline For Manson & $3 \%$ & $23 \%$ & $16 \%$ \\
\hline Primarily Women & $39 \%$ & $67 \%$ & $16 \%$ \\
\hline Lynette 'Squeaky' Fromme & $2 \%$ & $45 \%$ & $9 \%$ \\
\hline Family & $49 \%$ & $77 \%$ & $9 \%$ \\
\hline Leslie Van Houten & $44 \%$ & $35 \%$ & $1 \%$ \\
\hline Weak/Vulnerable Followers & $4 \%$ & $25 \%$ & $3 \%$ \\
\hline Still Has Followers & $6 \%$ & $40 \%$ & $6 \%$ \\
\hline Young Followers & $26 \%$ & $38 \%$ & $1 \%$ \\
\hline Followers Unbalanced & $6 \%$ & $25 \%$ & $3 \%$ \\
\hline Susan Atkins & $45 \%$ & $53 \%$ & $0 \%$ \\
\hline Robots/Slaves/Zombies & $5 \%$ & $25 \%$ & $0 \%$ \\
\hline Charles 'Tex' Watson & $23 \%$ & $30 \%$ & $0 \%$ \\
\hline Patricia Krenwinkle & $42 \%$ & $40 \%$ & $0 \%$ \\
\hline Linda Kasabian & $24 \%$ & $40 \%$ & $0 \%$ \\
\hline Sandra Good & $2 \%$ & $33 \%$ & $0 \%$ \\
\hline
\end{tabular}

A series of chi-square tests were done. Significant differences were found in all cases. When the frequencies from The New York Times were compared with the frequencies from the magazine articles from Reader's Guide, a chi-square value of 169.52 was found $(15 \mathrm{df}, \mathrm{p}<.001)$. When The New York Times frequencies were compared to the frequencies for 
the Manson survey, a chi-square value of 28.70 was found ( $5 \mathrm{df}, \mathrm{p}<.001)$. When the frequencies for the magazine articles from Reader's Guide were compared with the frequencies for the Manson survey, a chi-square value of 31.28 was found $(4 \mathrm{df}, p<.001)$.

\section{Inter-rater Reliability}

Much of the research done for the present study involved content analysis. Inter-rater reliability was asessed for the essay portion of surveys.

Percent agreement was determined. For the Manson survey there was $86 \%$ agreement. For the single case form of the comparable cases questionnaire there was $86 \%$ agreement, which was reduced to $85 \%$ when the no answer category was deleted.

Scott's Coefficient was also determined (Sackett, 1978). This statistic takes into account chance agreement. For the Manson survey this statistic was .84 . For the single case form of the comparable cases questionnaire Scott's coefficient was .84 which was reduced to .82 when the no answer category was deleted. 
The Manson case was a public event of some import. It was first presented to us by the press. An image quickly formed which was consistant with the image presented by the district attorney. It was a collage of the fears of the day, paired with an age old fear. There was wanton sex, drugs, throw away children, mysticism, the occult, all culminating in murder.

The journey from the original media image to the popular image which still exists bears a strong resemblance to rumor formation (Allport \& Postman, 1952).

The importance and ambiguity of this event made it fertile ground for this process. Most of the facts were present in the media image. However, the image was shaped by the highlighting of some points and the light coverage, and later deletion, of facts which did not fit the image.

The popular image of the Manson case, as determined by the Manson survey, carries the processes of sharpening and leveling even further. Aspects of the case which would seem to be crucial drop out completely, such as the identity of the actual murderers. 
What resulted was a sort of mythic representation of a real event. While many of the facts are represented in this image, the highlighting of certain points and deletion of other points leaves us with an image of this event that resembles the actual event in the same way a homunculus resembles a human being.

Why this happened is best prefaced with a quote about the embedding process:

Although the process is complex (involving, as it does, leveling, sharpening, and assimilation), its essential nature can be characterized as an effort to reduce the stimulus to a simple and meaningful structure that has adaptive significance for the individual in terms of his own interests and experience (Alrport \& Postman, 1952)

The 1960's were a time of great and rapid change. Change in and of itself is stressful. Beyond this, the particular changes which were taking place were found to be very stressful to many people. The Manson case was seen as the end of the counter culture by many, several articles in the conservative press are thinly veiled celebrations of this vision.

The following discussion will first examine the media image of the Manson case and its progression. It was the precursor to the popular image. The development of the popular image, out of the media image, will follow. The changes in the image, and some of the reasons for these changes, will be explored. This will be followed by an exploration of the mythic representation and the needs that it filled. 
The Media Image

The Manson case is unrivaled in the amount of coverage it received by the popular press. All other cases of murder which were examined received considerably less coverage. The Manson case has been the subject of 68 magazine articles which are cited in Reader's Guide, the comparable cases which received the most coverage by magazines were the Zebra case, the Alday family murder case, and the Sal Mineo case, each of these cases had five articles written about them. The difference between the coverage of the Manson case and comparable cases in the newspapers is even more astounding. The Manson case received 297 days of coverage in The New York Times, as compared to 45 articles written about the Corll case, the closest contender. No case since Jack the Ripper has been so appealing or created so much interest. It was felt that there might be a particular aspect of the Manson case that was so horrifying or so bizarre that that particular aspect might have caused the notoriety of this case. When subjects rated the Manson case and the comparable cases on horribleness, there was no significant difference among the cases in either the single case form or the multiple case form of the comparable cases survey. When these cases were rated on bizarreness, some differences were found. However, most of the cases were seen as not significantly different in bizarreness. The fact that for the most part no difference existed among the cases would indicate 
that the particular aspects which were examined were not in and of themselves responsible for the extent of coverage given to the Manson case.

Although it would appear that no single aspect of the Manson case was responsible for the notoriety of the case, one might wonder if a number of horrifying or bizarre aspects might have this effect. While this would logically seem to be the case, some of the most horrible and bizarre murder cases receive the least coverage. It is almost as if there is an upper threshold. Though the comparable cases are an impressive collection of the nether reaches of human potential, they do not include the most horrible cases. Brief accounts of three such cases will illustrate the point. None of these cases was covered to any great extent by the popular press.

Ed Gein became a suspect in the killing of a store keeper in the small Wisconsin community where he lived in 1957. When the police arrived at his farm to investigate, they found the woman's body in the barn. It had been dressed out, like a slaughtered animal, and was hanging from the rafters by the ankles. When they searched the house they found a number of body parts adorning the house. These included a hanging head, skulls on the bed posts and chairs which he had covered with human skin. He had also made various articles of wearing apparel from body parts, including a belt studded with nipples and a vest of skin complete 
with female breasts. Also found were shoeboxes containing female organs. On moonlit nights he would put on the vest, a pair of women's panties filled with the female organs, and prance around his farm. As well as the murder of the store keeper, he was suspected of other murders. He admitted to at least one other murder, and to robbing graves. He was also a necrophile and a cannibal (Gollmar, 1981; and Wilson, 1969).

Vaughn Greenwood was arrested for a series of murders of vagrants on Los Angeles' skid row. The press dubbed him The Skid-Row Slasher. He would approach someone who had passed out in an alley, slit their throat to the spine, drink cupsful of their blood, scatter salt around the body, take off their shoes and point them toward their feet, and then go home. He is responsible for at least nine murders. It is difficult to know because another murderer whose victims were vagrants was operating in Los Angeles at the same time (Levin \& Fox, 1985).

Henry Lee Lucas was arrested in the fall of 1982 by a Texas Sheriff who suspected him of murdering a local woman. He was arrested on a weapons charge. He soon began to confess. However, his confession was not limited to the one woman the Sheriff suspected him of murdering. When he had finished he had confessed to three hundred and sixty murders, committed across the country. He traveled with another man, Otis Toole, who shared his predilection. He bragged 
that he had killed every way known to man, and this would seem to be the case. It must be noted here that he has since recanted much of his confession. While it is doubtful that he committed all of the murders to which he originally confessed, it appears that he is responsible for the greater portion of the murders (Levin \& Fox, 1985; and Sonnenschein, $1985)$.

Given these cases, it would seem that a number of horrifying and bizarre aspects are not necessarily enough to cause a murder case to receive the extent of coverage that the Manson case received. To suggest that it was the particular constellation of qualities found in the Tate-Labianca murders borders on magical thinking.

The actual murders and the physical evidence were given very little attention. Of the seven magazine articles and thirteen New York Times articles that appeared prior to the arrest of the defendants, the vast majority were devoted to Sharon Tate, the lifestyle of the victims, and theories about the murders. Of the sixty-one magazine articles and two hundred and eighty-one New York Times articles published after the arrests, most were written about the defendants, their lifestyle and the trial. The murders seemed almost incidental.

The first two magazine articles to be published after the arrest of the defendants were The Demon of Death Valley (Time, December 12,1969 ) and Case of the Hypnotic Hippie 
(Newsweek, December 15, 1969). The titles of these articles indicate where the real interest was. They concentrated for the most part on Charles Manson. One could easily read these articles and still not know who had actualiy committed the murders. A brief quote from Case of the Hypnotic Hippie is representative of this early coverage:

And the most fascinating element of it all was Manson himself, a silken-voiced nouveau guru with an 01d Testament beard, the eyes of Rasputin and a line of mystical patter that mixed the Beatles with scientology. For Manson, who had spent some seventeen of his first 33 years behind bars for auto theft, forgery and other offenses before evolving his new mystic hussle (sic), the bloodletting in the Hollywood Hills seemed the almost logical culmination of a life that seemed born to be wild.

The defendants and the life they led were the foundation for an image which was loosely based on elements which existed to some extent.

The chief prosecutor, Vincent Bugliosi, was without a doubt the author of the media image. Aithough the early articles were based on testimony given to the Grand Jury by Susan Atkins, it was Bugliosi who was asking the questions. He was most certainly not a man without a plan.

Bugliosi had been working on the Manson case for some time before the defendants were arrested. While it is not required of the prosecution to establish a motive, when there is little hard evidence linking the suspects to the murders, it may be the only possibile avenue to conviction. At the time of the arrests the only physical evidence that was available to the prosecution was a fingerprint left by 
Charles watson on the front door of the Tate residence. The value of this evidence was limited by the fact that watson was known to have visited the residence at 10050 Cielo Drive prior to the murders, and the fact that he was successfully fighting extradition from Texas and would most probably not be tried with the others.

Their case was weak. The testimony given by Susan Atkins before the Grand Jury, while instrumental in obtaining warrants, could not be used against her or the other defendants. The weakest case of all was the case against Charles Manson. It was general consensus that the case could not be won.

In the early stages of the case it seemed that the only way to obtain a conviction against all of the defendants was to prove conspiracy. Not an easy task. But necessity is the mother of invention. Bugliosi was luckier than most inventors, he found a mass market that was anxiously awaiting his product.

The press does not print stories that no one wants to read, at least not repeatedly on the front page. In this respect the coverage of an event is a measure of the needs, thoughts and feelings of the people at the time. An excerpt from an article published in Life on December 19, 1969 entitled The Wreck of the Monstrous Manson Family is indicative of the thoughts and needs at that time, and of how the press met those needs: 
The Los Angeles killings struck innumerable Americans as an inexplicable controversion of everything they wanted to believe about the society and their children--and made Charles Manson seem to be the very encapsulation of truth about revolt and violence by the young.

The 1960's were a very tumultous time. The stress of the times had prepared people to accept in real life a scenario which it is doubtful they would have accepted in fiction.

A madman comes out of the darkness of the prison he knows as home. He dons the clothes and ideas of the day. Through his nearly magical powers he manages to attract and bind to him a number of young women. He corrupts these normal middle class children, replacing their wholesome values with drugs, wanton sex and hatred for society. Having prepared them, he sends them out to commit horrible murders for him. Soon little Susan Atkins who wanted to be a June Taylor dancer, and little Patricia Krenwinkle who used to sing in the church choir were wreaking havoc by remote control. All an intricate part of a master plan; they would start a race war, escape to the desert to avoid the mess, and return one day to rule.

That was helter skelter, as conceived by Bugliosi. It became the media image as well. The later release of the book Helter Skelter (Bugliosi \& Gentry, 1974) and the subsequent movie by the same name helped to keep this image alive. A passage from a review of the book is representative of the extent to which this theory was believed: 
The entire notion is so quirky, inconsistant and psychotic that it seems a remarkable accomplishment on Manson's part that he managed to sell it to his unimaginative, middle-class band of runaways. And it's as much an accomplishment on Bugliosi's part that he unraveled the whole twisted ideological package. But most to the prosecutor's credit is that he managed to turn around and sell it himself to an unimaginative middle-class jury. In that courtroom feat, more than any other, Charles Manson truly met his match (New York Times, Rogers, 1974).

Apparently the irony of sitting in wonder that Manson could sell this idea to unimaginative runaways, while all the time Rogers himself is believing it, escaped the author. This is not an uncommon affliction. In an article in The New York Times, on October 26, 1973, the following passage appeared:

Although Charles Manson, the convicted murderer of Sharon Tate, the actress, and six others, seemed to have a Svengali-like, hypnotic hold over his cult followers, some of whom were convicted with him, he apparently enjoys no such powers at Folsom Prison in California. "He doesn't have any hypnotic hold on any of these inmates, "said a prison spokesman, who depicted Manson as "a loner" who rarely leaves his cell.

The Popular Image

It would seem that most people in this country are familiar with the Manson case to some extent. All of the subjects who answered the Manson survey at least associated him with murder. When asked to identify every mass murderer they were aware of, Charles Manson was mentioned more frequently than any other murderer or murder case. And when a poll was taken, the percentage of people who identified 
Charles Manson was $87 \%$. None of the comparable cases were identified to a substantial extent.

In general, familiarity with a murder case can be related to geographical proximity, proximity in time or notoriety. Clearly, notoriety is the quality on this list which most closely fits this case. The media created an image. That image was consumed on a mass scale. It filtered down through society and a popular image was born.

While the overwhelming familiarity with this case is so readily apparent, the depth of that familiarity is less than one might expect. While the most outstanding features of the media image are present in the popular image, many of the details have been changed or deleted. While almost all of the subjects knew who Charles Manson was, few of them knew who the other defendants were. It is almost as if young female followers have become a part of Charles Manson's character, rather than real people. Charles Manson is no longer the leader of a group that murdered, he is a mass murderer; he is almost mass murder itself.

This does reflect the press coverage to some extent. As soon as they were arrested the case which had been known as the Tate case became the Manson case. In a great deal of the newspaper coverage Susan Atkins, Leslie Van Houten and Patricia Krenwinkle were referred to merely as the co-defendants. The major focus has been on Manson from the beginning, and remains there. 
Facts that did not fit the image were simply ommitted. Prior to meeting Manson, Susan Atkins appeared in a commercial presentation of a black mass, produced by Anton LaVey founder of the San Francisco based First Church of Satan. She took LSD before the performance, and it was delayed because she didn't want to come out of the coffin. It seems that she left little room for corruption. This definitely goes against the general media image, and it was rarely referred to.

The popular image is composed more of feelings than of facts. $70 \%$ of the subjects who answered the Manson survey stated that Manson should never be paroled, while $28 \%$ said that the followers should never be paroled. $64 \%$ of the subjects said Manson should have been executed, while $39 \%$ of the subjects said that the followers should have been executed. The most common response to the question, why did this happen, was that Manson was crazy. In general, the subjects were more forgiving of the actual murderers than of Manson. A response that would seem to be based more in feeling than in logic.

At some point, Charles Manson became a villian, a boogie man, a bigger-than-life symbol. At that point the facts became less important.

\section{The Myth}

It's like this: a guy comes up to you and he's called a district attorney. He's got all these guys and he handcuffs you, and he sets you down. And 
he says, "You're going to play this game whether you want to play it or not." So they start dealing out cards. And they deal you "hippie cult leader." you don't know what a hippie cult leader is. There's never been a hippie cult leader. So you got to go find out what a hippie cult leader is. And you say, "All right, I've got a hippie cult leader card. I've got nine murder cards." I'm supposed to be responsible for making all these people do all these things. I'm supposed to have this awesome power to move people to destruction and have the power of the presidency that I can put troops in the field and have them go out and die and take other people's lives for me. I'm a whole government by myself, convicted to be that. That's not me (Charles Manson in: Kennedy, 1985).

Distortion of the facts is common to mythic representations. The Dracula myth, as represented in the novel by Bram Stoker, is based on the life of a real person. He was a Romainian prince in the fifteenth century, Vlad Tepes, known as Vlad the Impaler. He murdered with impunity, for pleasure, for decades. Distortions of similar proportions took place with regard to the Manson case. Though this seemed to evade most writers, it was also noted by a few:

We are presented with Manson as Rasputin-a figure of great power and psychic force. The newspapers created him in that image as a public service, to offset the furry fear. Manson cannot be presented as what he is; if he is to contain our fear he must be large. He must be a monster of horror-film dimensions in order that we not be ashamed of our fear. It was only our fear, really, that we were ever concerned with (Conroy, 1970).

But anything this large is not built without reason. Fear may have been the reason, but fear of what? Not of murder. Murders have happened before and they will continue to happen. 
The fact that $27 \%$ of the magazine articles said that the Tate-Labianca murders were a sign of the times and $10 \%$ of the magazine articles indicated that these murders marked the end of an era might tell us something. In his summation defense attorney, Paul Fitzgerald, said, "What has really been on trial here since the middle of last June was the lifestyle of the 36-year-old hippie cult leader." This sentiment was expressed in various articles written about the Manson case:

Clearly, Charles Manson already stands as the villain of our time, the symbol of animalism and evil. Lee Harvey Oswald? Sirhan Sirhan? Adolph Eichman? Misguided souls, sure, but as far as we know they never took LSD of fucked more than one woman at a time (Felton \& Dalton, 1970).

Perhaps, too, we put too much weight on Manson. It's almost as though we needed him, a personification. Youth in the 1960's proposed to us that it was better than we were. Thus it was necessary that for every Woodstock there had to be an Altamont. Manson cancelled out the flower children (Leonard, The New York Times, April 11, 1975).

In the interview with Charles Manson in California (Kennedy, 1985), Manson maintains, as he did at the time of the trial that he was not a hippie. He seemed amazed that "you guys blame me for the sixties." This was expressed by others at the time of the trial:

The Manson we can never know, the one who underneath all the low theater about God and Satan does not pretend to be a prophet of the apocalypse, he came of age in the $50^{\prime} \mathrm{s}$, does he savor the irony of being the Body Snatcher of our time, when the devil theory applies mainly to the young? Only under these terms could someone be fried for hypnotizing others to murder (singer, 1970). 
While the liberal press hailed the warning, the conservative press was more than happy to lower the curtain on the $1960^{\prime} \mathrm{s}$ :

There is a special justice in the Manson-counterculture link. Not all counterpeople are prospective Mansons, as the hippie-haters hastened to claim. But the counterculture, that reductio ad absurdum of liberal humanism, was the perfect growth medium for Manson (Simonds, 1971)

May it not also be true, just because Manson has been so widely perceived as representative, perceived as the terminal stage of a disease from which an entire subculture has been suffering, that he has dealt that subculture a mortal blow, broken its spirit. The Tate killings, the drug suicides of Janis Joplin, Jimi Hendrix--all coalesce to shed an eerie light on Doing Your Own Thing. That is where the flowers have gone (National Review, February 9 , 1971).

Charles Manson has become a part of our culture, a metaphor for evil and madness. References to him occur in such diverse places as Woody Allen's movies Manhatten and Annie Hall, Joan Didion's book The White Album, skits on Saturday Night Live, quotes from Frank Sinatra and the comedy routines of Gallagher and David Steinberg.

The nature of these references make it clear that Charles Manson has become a symbol. Their intent is to evoke a set of emtions. While talking about critics, Frank Sinatra said, "I am convinced that they are decendants of Attila the Hun, Hitler, and Charles Manson" (Botts, 1980). While on the Tonight Show, David Steinberg said, "Putting Watt in control of the enviornment is like putting charles Manson in charge of a day care center." 
Perhaps he has received one of the harshest sentences ever passed, he is now more and less than a person. The myth survives.

\section{QUALIFIER}

I would not want anyone reading this document to misunderstand my contention that this case has been misrepresented. I do not believe that the wrong people were convicted. The evidence is overwhelming. While Charles Manson was not at the Tate residence, his knowledge of this crime and his participation in other crimes constitute culpability. As evidenced in the recent interview in California (Kennedy, 1985), his ideas remain hostile and violent. This is not a plea on his behalf.

\section{POSSIBILITIES FOR FURTHER RESEARCH}

While working on the present study, I developed an interest in the area of mass and serial murder. To say that a small amount of research has been done in this field may be an understatement. With the possible exception of another case study of Jack Graham, which would be difficult since he was executed in 1957, one could do almost any sort of research without fear of duplicating previous work. There is very ittie--almost none.

Documentation of some of the common assumptions would be one possibility. What does typically white, typically male and typically twenty-five to thirty-five mean 
statistically? Is there an increase in this sort of murder? If so, when did it begin, how quickly is it increasing and, what might be the reasons for such an increase? What behaviors can be considered to be precursors of this sort of behavior? Really, the questions are endless. 
BIBLIOGRAPHY A

GENERAL REFERENCES

Allport, G.W. and Postman, L.F. Public Opinion as collective Problem-solving. In Swanson, G.E., Newcomb, T.M., and Hartley, E.L. (Eds.), Readings in Social Psychology. New York: Henry Holt and Company, 1952 .

Altman, J. and Ziporyn, M. Born to Raise Hell. New York: Grove Press, 1967.

Atkins, S. Child of Satan, Child of God. New York: Logos Internationa, 1977.

Baer, R. The Manson Trial. Waco, Texas: Word Books, 1972.

Bishop, G. Witness to Evil. Los Angeles: Nash Publishing, 1971 .

Botts, L: Loose Talk: The Book of Quotes. New York: Quick Fox/Rolling Stone Press, 1980 .

Bruch, H. Mass Murder: The Wagner Case. American Journal of Psychiatry, 1967, 124, 147-152.

Bruning, J.L. and Kintz, B.L. Computational Handbook of Statistics. Glenview, IlTinois: Scott, Foresman and Company, 1968 .

Brussel, J.A. Casebook of a Crime Psychiatrist. New York: Bernard Geis Associates, 1968.

Bugliosi, V. and Gentry, C. Helter Skelter. New York: Bantam Books, 1974.

Capote, T. In Cold Blood. New York: Signet, 1965.

Chaney, M. The Co-ed Killer. New York: Walker and Company, 1976 .

Didion, J. The White Album. New York: Pocket Books, 1979.

Eveseeff, G.S. and Wisniewski, E.M. A Psychiatric Study of a Violent Mass Murderer. Journal of Forensic Sciences, $1972, \underline{17}, 371-376$. 
Felton, D. and Dalton, D. Charles Manson: The Incredible Story of the Most Dangerous Man Alive. Rolling Stone.

Foucault, M. (Ed.) I, Pierre Riviere, having slaughtered my mother, my sister and my brother... New York: Pereguine Books, 1975.

Freeman, L. Before I Kill More. New York: Pocket Books, 1955 .

Galvin, J.A.V. and MacDonald, J.M. Psychiatrict Study of a Mass Murderer. American Journal of Psychiatry, 1959, 115, 1057-1061.

Gaute, J.H.H. and Ode11, R. Murderer's Who's Who. New York: Metheun, $197 \overline{9}$.

- Murder 'Whatdunit'. New York: St. Martin's Press, 1982 .

Godwin, J. Murder USA. New York: Ballantine Books, 1978.

Gollmar, R.H. Edward Gein: America's Most Bizarre

Murderer. New York: Pinnacle Books, 1981.

Hacker, F.J. Crusaders, Criminals, Crazies. New York: Bantam Books, 1976 .

Haines, M. Bothersome Bodies. New York: McClelland and Stewart, 1977 .

Hellman, D.S. and Blackman, N. Enuresis, Firesetting and Cruelty to Animals: A Triad Predictive of Adult Crime. American Journal of Psychiatry, 1966, 122, 1431-1435.

Howard, C. Zebra. Berkley: Berkley Books, 1979.

Kahn, M.W. Psychological Test Study of a Mass Murderer. Journal of Projective Techniques, 1960, 24, 148-160.

Kennedy, K. Manson at 50. California. May 1985.

Levin, J. and Fox, J.A. Mass Murder: America's Growing Menace. New York: Plenum Press, 1985.

Levine, R.M. Bad Blood: A Family Murder in Marin County. New York: Signet, 1982 .

Livsey, C. The Manson Women: A "Family" Portrait. New York: Richard Marek Publishers, 1980. 
Lunde, D.T. Murder and Madness. Stanford: The Portable Stanford, 1975 .

McGuiness, J. Fatal Vision. New York: Signet, 1983.

MacDonald, J.M. The Threat to Kill. American Journal of Psychiatry, 1963, 120, 125-130.

Mendenhal1, W. and Ramey, M. Statistics for Psychology. North Scituate, Massachusetts: Duxbury Press, 1973.

Millet, K. The Basement: Meditations on a Human Sacrifice. New rork: Simon and Schuster, 1979.

Nash, J.R. Bloodletters and Bad Men. New York: Warner Books, 1973.

\section{8 .}

Murder America. New York: Simon and Schuster,

- Almanac of World Crime. New York: Anchor Press, 1981.

- Murder Among the Mighty: Celebrity Slayings. New York: Delacorte Press, 1983.

Noguchi, T.T. Coroner. New York: Pocket Books, 1983.

Packer, M.J. Hermeneutic Inquiry in the Study of Human Conduct. American Psychologist, 1985, 40, 1081-1093.

Porter, B. Mind Hunters. Psychology Today. April 1983.

Rohlf, F.J. and Sokal, R.R. Statistical Tables.

San Francisco: W.H. Freeman and Company, 1969.

Sackett, G.P. Observing Behavior. Baltimore: University Park Press, 1978 .

Sanders, E. The Family. New York: Avon, 1971.

Siegel, S. Nonparametric Statistics for the Behavioral Sciences. New York: McGraw-Hi17, 1956.

Smith, D.E. and Rose, A.J. The Group Marriage Commune: A Case Study. Journal of Psychedelic Drugs, 1970 , 3, $115-119$.

Sonnenschein, A. Serial Killers. Penthouse. February, 1985. 
Stack, A. Lust Killer. New York: Signet, 1983.*

Watson, C. Will You Die For Me? 01d Tappan, New Jersey: Fleming H. Revell Company, 1978.

Wilson, C. A Casebook of Murder. New York: Cowles Book Company, 1969 .

Wilson, C. and Seaman, D. The Encyclopedia of Modern

Murder. New York: G.P. Putnam's and Sons, 1985.

Zamora, W. Blood Family. New York: Kensington Publishing Corporation, 1976 .

* Andy Stack is the name that Ann Rule once wrote under, she now writes under her real name. 
B IBLIOGRAPHY B

\section{MAGAZINE ARTICLES ABOUT MANSON \\ CITED IN READER'S GUIDE 1969-1984}

Adelson, S. Emerging From Her Grief, Gwen Tate Crusades to Keep Sharon's Murderers in Jail. People.

September 13, 1982 .

Buckley, W.F. Is Nixon Guilty? National Review. August 25,1970 .

Cleath, R.L. From Manson to the Master. Christianity Today. October 10, 1975 .

Conroy, F. Manson Wins! a fantasy. Harpers Magazine. November 1970 .

Coyne, J.R. Killing For Love. National Review. January 31,1975 .

Farrell, B. In Hollywood the Dead Keep Right on Dying.

Life. November 7, 1969.

. The Manson Jury: End of a Long Ordea 1. Life.

Apri1 16, 1971.

Geis, G. Women and Violence: The SLA. The Nation.

Keerdoja, E. Squeaky and Sara Jane. Newsweek. November 8, 1976 . - One Man's Family. Newsweek. January 23, 1978.

Mas, P. The Sharon Tate Murders. Ladies Home Journal. Apri 1970 .

Muggeridge, M. Milne and Manson: Two Styles of Fantasy. Esquire. JuTy 1975.

Roberts, S.V. Charlie Manson: One Man's Family. New York Times Magazine. January 4, 1970.

Rose, S.C. The Drug Culture's Satanic Messiah. The Christian Century. March 22, 1972. 
Sanders, E. Charlie and the Devil. Esquire. November 1971.

Simonds, C.H. Who killed the Counter culture. National Review. November 19, 1971.

Singer, M. Fragments From the Shooting Gallery. Ramparts. April 1970 .

Stafford, J. Love Among the Rattlesnakes. McCall's. March $19 \overline{70 .}$

Talese, G. Charlie Manson's Home on the Range. Esquire. March 1970.

Thompson, T. Tragic House on the Hill. Life. August $29,1969$.

Tracy, P. The Family. Commonweal. February 4, 1972.

Woods, W.C. Demon in the Counter Culture. New Republic. January 4, 1975 .

No By-line. Nothing But Bodies. Time. August 15, 1969. - The Hollywood Murders. Newsweek. August $18,1969$. - The Night of Horror. Time. August 22, 1969. - The Tate Set. Newsweek. August 25, 1969. - Ghoulish Moguls. Christian Century. September 17, 1969 . - The Demon of Death Valley. Time. December 12, 1969. - Case of the Hypnotic Hippie. Newsweek. December 15, 1969 . National Where Have All the Flowers Gone? - The Wreck of a Monsterous Family. Life. December 19, 1969 .

- Family Jams, Inc. Newsweek. January 19, 1970.

- A Martian Model. Time. January 19, 1970. March $\frac{\text { Sing Alo }}{16,1970}$ 
- The Family Hour. Newsweek. June 29, 1970.

Auguat The 0ther End of Society. Time.

. Of Murder and Messiahs. Time.

August 10,1970 .

- Helter Skelter. Newsweek. August 10, 1970.

- Nixon's Plea: Stop Making Heroes out of

Criminals. US News and World Report. August 17, 1970.

August $\frac{\text { Here's a }}{17,1970 .}$

- Just Waiting For Charlie. Life. Auguat 21, 1970.

- Linda's Punishment. Newsweek. August 31, 1970.

- Manson on the Stand. Newsweek.

November 30,1970 .

- Manson's Shattered Defense. Time.

November 30,1970 .

- The Manson Scene. Newsweek. January 4, 1971.

- Verdict on Manson. Newsweek.

February 8, 1971 .

Februar $\frac{\text { Manson Convicted. National Review. }}{9,1971 .}$

- Life with Father. Time. February 15, 1971.

The Magical Mystery Tour. Time.

February 22, 1971.

Aprii $\frac{\text { 'Death For the Family. Newsweek. }}{12,1971 \text {. }}$

Life Among the Manson Jurors. Time.

Apri 12,1971 .

- Death Sentence For Manson Clan, But-.

US News and World Report. April 12, 1971.

- Helter Skelter. Newsweek. October 28, 1974. imbe $\frac{\text { Anatomy of an Outrage. Time. }}{r, 1974 .}$ 
The Girl Who Almost Killed Ford. Time.

September 15, 1975 .

- The Family That Stays Together. Time.

September 15, 1975 .

The Memoirs of Squeaky Fromme. Time.

September 15, 1975 .

September 15, 1975 .

- The Story of Sqeaky. Newsweek.

September 15, 1975 .

September 22, 1975.

- Fromme: 'There's a Gun Pointed'. Time.

September 22, 1975.

- A Scare and a Bulletproof Vest. Time.

September 22, 1975 .

September 26,1975 .

- A Fool For a Client. Time. November 10, 1975.

- Squeaky and Jerry. Newsweek.

November 24, 1975 .

- Fromme's Fate. Time. December 8, 1975.

- Judgement on Squeaky. Newsweek.

December 8, 1975.

- Double Indemnity. Time. December 29, 1975. 
B IBLIOGRAPHY C

NEW YORK TIMES ARTICLES ABOUT MANSON

Brown, L. Manson Mania. April 18, 1976.

Broyard, A. More and Less About Manson. November 11, 1971.

Caldwell, E. Manson Put at Tate Home 5 Months Before

Killings. October 22, 1970.

- Manson Takes Seat in Courtroom Again as order

Prevails. October 23, 1970 .

- Record Producer Rejected Manson.

October 23, 1970 .

- Youth Testifies Manson Urged Him to Murder

Sheriff. October 28, 1970 .

- Manson Removed From Courtroom.

November 10, 1970 .

- Tate Witness Says She Hears Voices.

November 11, 1970 .

- Witness Testifies Manson Beat Her.

November 13, 1970 .

- Manson Accuser Upheld on Sanity.

November 14, 1970 .

- State Rests in Tate Murder Case; Manson Bid

Denied. $\frac{\text { November 17, } 1970 .}{\text { Nove }}$

- Manson Co-Defendants Allowed to Testify After

Defense Rests. November 20, 1970.

- Manson Tells Judge He Killed No One.

November 21, 1970.

- Manson's Prosecutor Outlines Testimony in Tate Murder Trial. December 22, 1970.

- Defense For Manson Derides Charges.

December 29, 1970 .

Defense Asserts State Produced No Evidence

Against Manson. December 30, 1970. 
Manson Arraigned in 2 More Murders.

December 31, 1971.

- 'Robot Theory' Cited in Defense of Manson's 3 Co-Defendants. January 13, 1971 .

Manson Prosecutor, in Closing, Assails Defense. January 14, 1971 .

- Tate Jury, Together Since JuTy, To Begin Deliberation Today. January 15, 1971.

- Coast Jury Gets Manson Case.

January 16, 1971 .

- Manson Jury Deliberates Under Heavy Security.

January 17, 1971 .

- Tate Jury Denied Death Site Visit. January 19, 1971 .

- Girl's Letters Reread to Manson Jury. January 20,1971 .

- Manson, 3 Women Guilty; Prosecution Asks Death. January 26, 1971. January $\frac{\text { Manson and } 3 \text { Face Penalty Jury Today. }}{28,1971 .}$

- $2 \mathrm{~d}$ Woman Admits Role in Tate-Labianca Slayings. February 19, 1971 .

- Tate Defendant Willing to Face Death. February 20, 1971 .

February $\frac{3 d \text { Woman Admits Role in Slayings. }}{23,1971 .}$

- Psychiatrist Assays Manson's Role. March 4, 1971.

- Interest Fading in Manson Trial. March 14, 1971.

- Final Plea Heard in Manson Trial. March 27, 1971.

- Jury Weighs Fate of Tate Slayers. March 28, 1971.

- Jury Votes Gas Chamber For Manson and 3 Women.

March $30,1971$.

March 31,1971 
California Court, in 6-1 Vote, Bars Death

Sentence. February 19, 1972 .

- Reporter in Contempt Case Being Held in

Isolation. December 15, 1972 .

Canby, V. 'Manson' Full-length Documentary Opens. January $27,1976$.

Christgan, R. The Family. October 31, 1971.

Gould, J. The Blooping of the President. August 23, 1970 .

Gussow, M. Stage: 'Rockumentary' About Manson. January 5,1972 .

Klein, T.E.D. Charles Manson, B.M.0.C. March 28, 1972.

Kneeland, D. Manson Mistrial Barred Again; Jurors Held Still Unprejudiced. August 6, 1970 .

- Manson Witness Shaken by Photo. August 7, 1970.

- Tearful Manson Witness Unyielding When Shown

Death Photos. August 8, 1970 .

- Manson Witness Given Immunity. August 11, 1970.

- Tate Witness Tells Murder Jury of Thinking She Was a Witch. August 12, 1970 .

- Witness Says She Stole $\$ 5,000$ Before Joining Manson 'Family'. August 13, 1970 .

- Witness Says Manson Gives off 'Vibrations' in

the courtroom. August 14, 1970 .

- Witness Says Manson Had Weapon Near Murder

Site. August 15, 1970 .

Witness Calls Manson the Devil and Says She is God's Emissary. August 18, 1970 .

- Manson Witness Terms Testimony Repentance.

August 19,1970 .

- Witness Says She Loves Manson and'All Mankind'.

August 20, 1970 .

- Manson Testifies on 'Harassment'.

August 21,1970 . 
Coroner Details the Tate Killings.

August 22, 1970 .

Coroner in Tate Case Shows Drawings of Wounds. August 24, 1970 .

- Coroner Asserts Sharon Tate Was Still Alive When Hanged. August 26, 1970.

- Manson Trial Hears Testimony on Bloodstains at Murder Scene. August 27, 1970.

Coast Trial Told of $2 d$ Crime Scene.

August $28,1970$.

- Manson Trial is Told Mrs. Labianca Was Stabbed 41 Times. August 29, 1970.

- Trial of Manson is Delayed Again.

September 2, 1970 .

Trial is Resumed in Tate Murders.

September 3, 1970 .

- Murder Suspects' Fingerprints Found at Tate

Home, Jury Told. September 4, 1970.

September 5, 1970 .

Manson Disciple Insists She Lied.

February 12, 1971 .

Lehmann-Haupt, C. Prosecuting the Manson Case.

November 8,1974 .

Leonard, J. TV Tackles Evil But Sidesteps Sin.

April 11, 1975 .

McFadden, R.P. Suspect Was Defender of the Manson 'Family'. September 6, 1975 .

Moore, C. How Much of Charles Manson Do His Songs Reveal? October 4, 1970 .

O'Conner, J.J. TV: 'Helter Skelter', on Manson, Avoids Titilation. April 1, 1975.

- Manson and Title Boxing. January 21,1981 .

Oelsner, L. High Court Refuses to Hear Appeal by Manson in 7 California Killings or to Review Death Sentence of Texan. ApriT 26, 1977. 
Reston, J. Washington Making Things Worse Than They Are. August 5,1970 .

Roberts, S.V. Actress is Among 5 slain at Home in Beverly Hills. August 10, 1969 .

Polanskis Were at Center of Rootless Way of Life. August 31, 1969.

- 3 Suspects in Tate Case Tied to Guru and 'Fami1y'. December 3, 1969 .

December $\frac{\text { Head of 'Family' is Held For Trial. }}{4,1969 .}$

- All the Twists Are Bizarre in the Tate Case. December 7, 1969 .

Charlie Manson, Nomadic Guru, Flirts With Crime in a Turbulent Childhood. December 7, 1969.

- Tate Judge Curbs Talk out of Court.

December 11, 1969 .

- The Hippie Mystique. December 15, 1969.

- Charlie Manson: One Man's Family.

January 4, 1970 .

State Gets New Star Witness in Tate Murder Case and Manson a New Lawyer in Pretrial Maneuvers.

March 23, 1970 .

Problem of a Fair Trial For Manson.

August 9,1970 .

- Manson: The Two Faces of a Man on Trial.

January 3, 1971.

Manson Case: People Keep Asking 'What Made

Those Kids Do It? January 31, 1971 .

Robinson, D. Manson Murder Trial Nears Opening.

June 15,1970 .

- Jury Selection in Manson Case to Begin Today.

June 16,1970 .

- Manson Orders Lawyer Not to Question Prospective Jurors. June 25, 1970 .

- Manson Gag Rule Brings Protest. June 29, 1970. 
- Manson Trial is Moved to Court. June 30, 1970.

- A Few Members of Manson's 'Family' Still Stay at Movie Ranch, Awaiting His Return. July 5, 1970. - Jury Completed in Manson Trial. July 22, 1970.

- Manson Called Meglomaniac by Prosecutor as

Trial Begins. Ju1y 23, 1970.

- Manson Councel objects to Key Witness.

JuTy 28,1970 .

JuTy $29 \frac{\text { Manson }}{1970 .}$

JuTy 30 Witness

Third Murder Plan is Laid to Manson.

JuTy 31,1970 .

- Key Witness Says That She Once Regarded Manson as a 'Messiah'. August 1, 1970.

Rogers, M. Helter Skelter. November 17, 1974.

Rugaber, $W$. Court Lets Newsman Remain Free in Watergate Tape Case. December 21, 1972.

Salinger, P. Exposing the President. September $24,1970$.

Semple, R.B. Nixon Calls Manson Guilty, Later Withdraws Remark. August 4, 1970 .

- Impulsive Nixon Action. August 5, 1970.

- Press Criticized on Nixon Remark.

August 6,1970 .

- Why a President Must Watch His Words.

August $9,1970$.

Shabecoff, P. Woman Not Listed as Security Peril.

September 6, 1975 .

Shipler, D.K. Reporter's Right to Silence Backed.

December 3,1972.

- Writs Against Reporters Arouse Debate.

January 7, 1973 . 
Turner, W. Caretaker, 19, is Freed in 5 Los Angeles Slayings. August 12,1969 .

- Five Girls Keep Three Month Vigil at Tate Trial. December 2, 1970 .

Ford Gun Inquiry Finds no Plot Evidence in Threat to

Ford. September

Waldron, M. Federal Agent Discounts Drugs as Motive in 5

Coast STayings. August 16, 1969.

- Polanski Denies Rumors on Party.

August 16,1969 .

- Slayings of Wife and Daughters by Four is

Reported by Captain. February 18, 1970.

- Friend Says Captain Discussed Tate Killing

Before Family Died. February 20, 1970.

- Witness Says He Saw Manson With Gun Like Murder Weapon. September 11, 1970.

- Tate Suspect Loses Extradition Fight.

September 12, 1970 .

- Witness Recalls Manson as 'Devil'.

September 18, 1970 .

- Witness Says He Spent 6 Months With Manson in Alcoholic Daze. September 19, 1970.

- Witness at Manson Trial Links Weapon to Ranch.

September 22, 1970.

2 Deputies Testify Manson Proposed Alliance With Police to Fight the Panthers. September 23, 1970.

- Witness Says Tate Defendant Talked of Slayings.

September 24, 1970 .

- Manson Witness Tells of Her Illness.

September 25, 1970 .

A Witness Testifies That Manson Told of 'Doing A11 Those Killings'. September 29, 1970.

- Tate Defendants Ousted by Judge. October 2, 1970.

- Trial is Resumed Without Manson. October 3, 1970. 
Manson Leaps at Judge in the Tate Murder Trial and Declares Someone Should Cut Your Head off'.

Manson Asserts Judge is Biased.

October 8, 1970 .

- Inmate Testifies on Tate Killings.

october 10,1970 .

- A Manson Motive is Heard at Trial.

October 18, 1970 .

Weaver, W. Reporter Freed in Contempt Case. January 12, 1973 .

Weinraub, B. 'If You Don't Show Violence the Way it is,'

Says Roman Polanski, I Think That's Immoral and

Harmful. If You Don't Upset People Then That's

obscenity. December 12, 1971.

Wright, R.A. 2 Held, One Sought in Tate Murders; Grand Jury to Act. December 2, 1969 .

Grand Jury Voted to Hear Evidence in Tate

STayings. December 3, 1969.

- Won't Disclose Sources. November 14, 1972.

November 17, 1972 .

Coast Reporter Ordered to Jail For Refusing to

Disclose Source. November 28, 1972 .

- Prosecutor and Manson Lawyer Indicted For

Perjury Over Leak. June 29, 1974.

Conflict Over Protection of News Sources Enters

New Phase Tomarrow in Farr Case in California.

JuTy 1, 1974 .

No By-line Several Suspects and Car Hunted in 5 Coast Killings. August 11, 1969 .

- Drugs Tied to Slayings. August 13, 1969 .

California. August 14, 1969.

Canadian Queried in Coast Slayings.

August $\overline{19}, 1969$. 
August $21,1969$.

- Frykowsky Body Claimed. August 22, 1969.

- Slain Woman Left $\$ 500,000$. August 24,1969 .

- Eyeglasses Called Key Clue in Slaying of

Sharon Tate. October 24, 1969.

- Woman Tells Grand Jury 'Details' of Tate

Slayings. December 6, 1969 .

- Five Are Indicted in Tate Slayings.

December 9,1969 .

- Manson Plea Set Dec. 22 at Hearing on Tate Case. December 12, 1969 .

Securit $\frac{\text { Hippie Leader in Tate }}{\text { Secember 14, } 1969 .}$

- Tate Extradition Authorized. December 16, 1969.

- Young Suspect in Tate Case Pleads Not Guilty on Coast. December 17, 1969.

- Tate Case Defendant Asks to Serve as Own

Attorney. December 18, 1969.

- Lawyer Named in Tate Case. December 20, 1969.

- Manson Wins Delay in His Plea and Scores 'Lies' in Tate Case. December 23, 1969.

- Manson to Represent Himself at Sharon Tate Murder Trial. December 25, 1969.

Governor of Texas Orders Extradition in the Tate Murder Trial. January 6, 1970.

- Psychiatrist to Examine Suspect in Coast Slayings. January 7,1970 .

- Girl in Tate Case Held. January $21,1970$.

- A Plea of Not Guilty Entered For Manson; Trial

is Feb. 9. January 29, 1970.

- Tate Case Trial Postponed. February 4, 1970.

- Tate Suspect is in Solitary for Violation of Jail RuTe. February $7,1970$. 
Dismissat Bid. February 10, 1970 .

- Manson Denied Change of Venue.

February 17, 1970 .

- Tate Defendant Arraigned. February 25, 1970.

- Tate Case Plea Rejected. March 4, 1970.

- Judge Bars Manson as Own Attorney.

March 7, 1970 .

- Tate Case Figure Has Baby. March 10, 1970.

- Tate Figure Seeks Lawyer. March 11, 1970.

- Tate Suspect Gets Lawyer. March 12, 1970.

- Manson Gets New Lawyer; Tate Murder Trial

Delayed. March 20, 1970 .

- Manson Trial Postponed. April 18, 1970.

Manson Associate Guilty of Murdering Musician.

Apri 119,1970 .

- Lawyer For Manson Named. April 23, 1970.

- Tate Suspect Extradited. May 7, 1970.

- Convict to Represent Himself. May 27, 1970.

- Trial in Sharon Tate Killing Gets Under way on

Coast. June 17, 1970 .

- No Manson Jurors Picked After 2 Days.

June 18,1970 .

Women. State to Seek D

Case. $\frac{\text { Jury Sketch by a Defendant Causes Delay in Tate }}{\text { JuTy } 9,1970 .}$

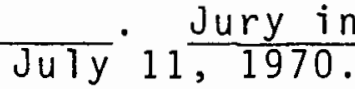

Jury Appears Set at Manson Trial. July 14, 1970.

Ju $7 \bar{y}_{15} \cdot \frac{7 \text { Men, }}{1970}$ 
- Manson Trial Proceeds Despite Nixon Comments.

August 4, 1970 .

- Nixon's Remarks on Manson and Statement in Washington. August 4, 1970 .

- Manson Displays to Jurors Headline on Nixon Remark. August 5, 1970 .

- Mr. Nixon's Loose Talk. August 5, 1970.

- Comment on Manson. August 7, 1970.

- Remarks on Manson. August 12, 1970 .

- Italian Movie Company to Make Movie About Tate

Murder. August 18, 1970.

- U.S. Court Denies Extradition Curb.

September 1, 1970 .

- Suspect in Tate Case Loses Extradition Appeal in Texas. September 9, 1970 .

- Extradition Delay Sought For Accused in Tate

Case. September 10, 1970 .

- Arraignment is Set For Watson Sept. 28 .

September 13, 1970 .

Witness Testifies to Fear of Manson.

September 26, 1970 .

- Trial of Manson Enters 16th Week.

September 27, 1970.

- Manson Follower Explains Silence.

September 30,1970 .

- Judge Bars Manson. October 9, 1970.

- Manson and Women Barred From Court.

October 10, 1970 .

- Manson Trial Goes Into It's 5 th Month.

- To Curb the Monster. October 25, 1970.

- Watson is Held Insane In Tate Murder Case.

0ctober 31, 1970 .

- Witness Supports Manson Accuser.

November 6, 1970 . 
- An Attorney Misses Tate Trial Session.

December 1,1970 .

- Ex-Member of Manson Group Held in Torture Case.

December 3, 1970 .

- Search For Lawyer in Tate Trial Ends.

December 7, 1970 .

- Tate Trial Lawyer is Now Feared Dead.

December 8, 1970 .

- Rights of Defendants. December 11, 1970.

- New Lawyer to Ask Tate Case Mistrial.

December 16, 1970 .

- 3 Indicted in the Slaying of Spahn Ranch Hand.

December 17, 1970 .

- Manson and Co-Defendants Barred From Court

Again. December 23, 1970.

- Manson Accused of Murder Lust.

December 24, 1970 .

- Jurors in Tate Trial Have Christmas Party.

December 25, 1970 .

- Manson's Lawyer Calls Murder Case 'A Political

Trial'. January 5, 1971.

- Manson Requests to Dismiss Lawyers Denied by

Judge. January 7, 1971 .

January $\frac{\text { Manson's Attorney Ends His Summation. }}{9,1971 .}$

- Manson Jury Deliberates Fifth Day Without

Decision. January 21, 1971 .

Jury Deliberates Sixth Day in Manson's Murder

Trial. January 22, 1971.

- Day Off For Manson Jury. January 25, 1971.

- Manson Ejected From Courtroom.

January 29, 1971 .

Triai. $\frac{\text { State Rests Case in }}{\text { February } 2,1971 .}$ 
February $\frac{5 \text { th Manson Figure Fit to Stand Trial. }}{5971 .}$

- Miss Atkins Testifies She Killed Sharon Tate;

Seeks to Absolve Manson. February 10, 1971 .

Night. $\frac{\text { Tate Trial Jurors Allowed to go Home Every }}{\text { February } 17,1971 \text {. }}$

March Defense and State Rest in Tate Trial.

$\operatorname{March} 17,1971$.

- Tate Murder Trial Costly. March 26, 1971.

- Body Identified in Tate Case. April 1, 1971.

- Protection. April 4, 1971.

- Court Rejects Manson Plea. April 15, 1971.

- Death Row Cells For Women. April 16, 1971.

Manson and 3 Formally Sentenced to Death.

Aprii 20,1971 .

Soon. $\frac{\text { Manson Enters San }}{\text { April 23, } 1971 \text {. }}$

il Watson Pleads Insanity in Sharon Tate Case.

May $11, \frac{1971 .}{197}$

- Former Coast Newsman Sentenced For Contempt.

JuTy 29,1971 .

- 4 Watson Jurors Excused. August 4, 1971.

- Jury Picked in Tate Trial. August 11, 1971.

- Watson Tells of Rampage at Home of Sharon Tate.

September 2, 1971 .

- Watson Admits Killing 7 Under Manson's Influence.

September 3, 1971 .

- Jail Penalty For Manson. September 15, 1971.

- Watson Convicted of Tate Murders; Faces Sanity

Trial. October 13, 1971 .

- Jury Rules Watson Sane. October 20, 1971. 
- Manson Aide Captured After Flight From Jail.

0ctober 21, 1971.

- Watson Sentenced to Death For a Part in Tate Murders. October 22, 1971.

- Manson Jury Recessed. October 31, 1971.

Manson is Found Guilty of Two More Murders.

November 3,1971.

- 7th Manson Case Sentencing. November 9, 1971.

- Watson Formally Sentenced to Death For Tate

Murder. November 12, 1971.

- Coast Trial is Ordered. November 14, 1971.

- Manson Sentenced. November 30, 1971 .

Order. $\frac{\text { Tate Trial Reporter Cleared on Violation of Gag }}{\text { December } 8,1971 .}$

- Manson Given Life Term. December 14, 1971.

- Manson Follower Convicted. December 15, 1971.

- Manson Shifted to Folsom. October 1, 1972.

Novembe $\frac{\text { High Court }}{r 14,1972 .}$

- 5 Linked to Manson Are Held in Slaying.

November 14, 1972 .

- Coast Reporter Again Told to Disclose Source.

November 16, 1972 .

Novembe $\frac{\text { Reporter on }}{22,1972 .}$

- Coast Court Urged to Free Reporter.

November 29, 1972 .

- California Justices Reject Writer's Bid For

Release. November 30, 1972 .

- Herbert Klein Criticizes Jailing of 2 Reporters.

December 2, 1972 .

- Coast Newsmen File Suit to Free Jailed Reporter.

December 16, 1972 . 
- Reporter Loses in Attempt to Be Freed For

Birthday. December 23, 1972.

- Sheriff Asked For Briefs on Farr Bid For

Freedom. January 6, 1973 .

Newsman. Judge Bars Suit to Prevent Jailing of Coast

- Notes on People. October 26, 1973.

- Reporter Gains in Fight to Avoid Jail.

January 10, 1974.

- A Beneficial Silence. January 13, 1974.

- Reporters' Silence Backed by Cronkite.

May $21,1974$.

- Jajled Reporter Free. June 21, 1974.

- Manson Case Reporter Again Held in Contempt.

June 28,1974 .

- A Contempt Plea Won by Reporter. July 3, 1974.

Farr Gets Sentence of 5 Days and $\$ 500$.

JuTy 30,1974 .

- Perjury Hearing Delayed. August 17, 1974.

- Action by Reporter Ends Perjury Case.

October 4, 1974 .

- No Further Contempt For Coast Writer.

December 8, 1974 .

August $\frac{\text { Manson Ca }}{13,1975 .}$

- Miss Fromme Indicted Under Law on Presidents' Assasinations. September 11, 1975 .

Miss Moore Aided U.S. Firearms Unit Day Before Attack. September 26, 1975.

- Former Manson Follower is Freed by Coast Judge. November 5, 1975 .

- Susan Atkins. December 28, 1975.

'Heiter Skelter' Gets 57 Percent of Audience.

Apri1 5,1976 . 
- Notes on People. April 17, 1976.

Judge Will Review Conviction of Manson.

May $21,1976$.

Reporter in Manson Case Aga in Ordered to Jail.

JuTy 11, 1976.

Contempte Sentence Voided Against Coast

Reporter. December 7, 1976.

- Cal ifornia Supreme Court Denies Manson Appeal.

December 10, 1976 .

Former Manson Follower Faces a New Trial Jan. 28. December 28, 1976 .

- Reporter Who Refused to Disclose His Sources

Faces Questions Anew. Jamuay 2, 1977.

- Former Manson Cultist to Testify at Retrial.

January 5, 1977 .

- Notes on People. January 21, 1977.

- Murder Retrial Postponed For Manson Case Figure.

January 29, 1977.

- Manson Asks High Court to Overturn Conviction.

March 10, $197 \overline{7}$

Manson Family Member Starts 2d Murder Trial.

March $2 \overline{9,1977 .}$

- Ex-Manson Cultist Tells of Assurances to Victims.

Aprii 26,1977 .

- Retried in Labianca Murder Case. April 27, 1977.

- Manson Follower's Retriaj to go to Jury Next

Week. June $30,1977$.

- Manson Case Jury Deadlocked. August 6, 1977.

- Mistrial Ruled For Manson Disciple.

August 7, 1977 .

\$I Million Spent to Re-try Ex-Follower of Manson. August 20, 1977.

- Leslie Van Houten Faces Third Trial For Murder.

September 2, 1977. 
- Trial Postponed. September 13, 1977.

- Judge Named to Coast Trial. September 25, 1977.

- 2 Manson Attorneys Sue a Reporter.

January 12, 1978 .

- A Manson Family Member Again Convicted of Murder.

JuTy 6,1978 .

- Manson Aga in Denied Parole in Tate Slaying.

November 28, 1979 .

- Manson Gets Some Air. August 7, 1980.

- Follower of Charles Manson Denied Parole For

Murders. July 13, 1981 .

Manson Denied Parole For 4 th Year in a Row. November 5, 1981 .

- Disciple of Manson is Denied Parole on Her Life Sentence. December 18, 1982.

- Manson is Set Ablaze by Inmate in California. September 24, 1984.

- Manson Loses Much Hair. September 27, 1984. 


$$
\text { APPENDIX A }
$$

\section{COMPARABLE CASES}

The first form was included with each survey instead of a consent form. It was felt that a form that must be signed would undermine assurances about anonymity. When all the cases were to be administered at one sitting, it was indicated that they would need to read thirteen cases and that it would take about two hours.

The first cover sheet accompanied the survey when the subjects received a single case. When all cases were given to one subject at one time, the second cover sheet accompanied a packet which included a copy of each case with the questionnaire appended.

The heading which identifies each case has been added here to facilitate discussion. Since one of the questions in the survey asks the subject if they can identify the case or any of the principals in the case, this was not included on the survey form.

On the original survey form, space was left for subjects to make any comments they wished, after most questions. This has been deleted in the interest of space. 
This questionnaire is part of a thesis being done by a graduate student in the Psychology Department. While your help would be greatly appreciated, participation in this study is completely voluntary. Non-participation will not affect your grade in class. If you decide not to complete this form, please return it before leaving. In order to answer this questionnaire, you will need to read a short account of an actual murder. This account may be graphic. If you find this distressing, you need not answer this questionnaire. It will take approximately half an hour to complete. Your response will remain anonymous. If you have any questions or want to talk to someone, contact the person administering this questionnaire.

If you have answered a questionnaire on a similar topic, please indicate:

In what class

Who was the instructor

What was the questionnaire about

If you have answered this questionnaire before, please put a check on this line and return the form 


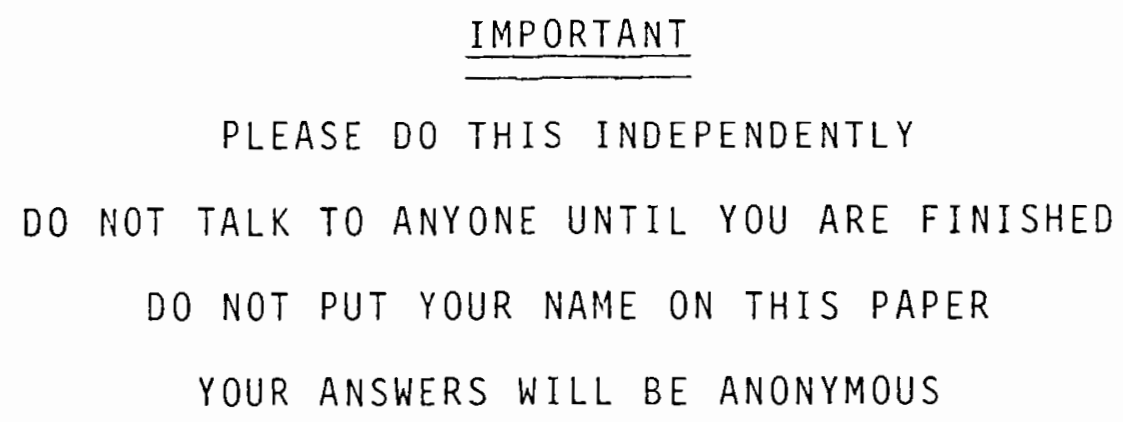

YOUR ANSWERS WILL BE ANONYMOUS

Your age___ Sex__ National Origin

Where have you lived most of your life? (City, State/ Country)

For most of your life since age 16? (City/State, Country)

At what age did you become aware of the news to the extent that you were aware of most current events? (Reading newspapers, watching TV news regularly, discussing current events, etc.)

Age

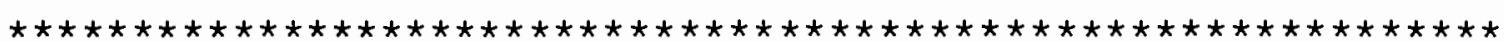

Please read the following murder case carefully. Then answer the questions that follow, feeling free to refer back to the account of the case. Thank you for helping. 


\author{
IMPORTANT \\ PLEASE DO THIS INDEPENDENTLY \\ DO NOT TALK TO ANYONE UNTIL YOU ARE FINISHED \\ DO NOT PUT YOUR NAME ON THIS PAPER \\ YOUR ANSWERS WILL BE ANONYMOUS
}

Your age

$\operatorname{sex}$ National Origin

Where have you lived most of your life?

(City, State) Country)

For most of your life since age 16? (City, State/Country)

At what age did you become aware of the news to the extent that you were aware of most current events? (Reading newspapers, watching TV news regularly, discussing current events, etc.)

Age

Please read all of the murder cases carefully. Then go back and read each separately and answer the questions with each case. DO NOT ANSWER ANY OF THE QUESTIONS BEFORE YOU HAVE READ ALL OF THE CASES.

After you have answered the questions for all of the cases, please order the cases from the least horrible to the most horrible. Do this by putting a number in the upper lefthand 
corner of each of the 13 cases. The least horrible case should have a 1 in the upper lefthand corner and the most horrible should have a 13 in the upper lefthand corner. The rest of the cases should have a number between 1 and 13 in the upper lefthand corner, depending on where you feel they lay in relation to the other cases.

Once you complete this task, you probably deserve a medal! Short of that, I would like to thank you very much for your help. 
1) Were you familiar with this case before reading this account? Yes__ No

2) Do you know the name of the murderer/murderers, or the name given to the case by the press? Yes No

3) If you are familiar with the case, where did you learn what you know? Check all that apply. Newspapers__ Radio__ TV__ Magazines__ Word of Mouth_B_ Books___ Other (Please specify)

4) Why do you think the murder/murders happened? Please say anything you believe, your answers are anonymous.

5) Do you think the murderer/murderers should be paroled? (Circle one)

\begin{tabular}{llccccc}
\multicolumn{1}{c}{-3} & -2 & -1 & 0 & +1 & +2 & +3 \\
\hline NEVER & STRONGLY & MILDLY & INDIF & MILDLY & STRONGLY & RELEASE \\
RELEASE & OPPOSE & OPPOSE & FERENT & FAVOR & FAVOR & AT ONCE \\
& RELEASE & RELEASE & & RELEASE & RELEASE &
\end{tabular}

6) What do you think should have happened to the murderer/ murderers after being convicted? You may say anything you really mean, your answers are anonymous.

7) Do you feel that the murderer/murderers are crazy? Yes No

8) How does this case affect your feeling of safety? (Circle one)

\begin{tabular}{lllllll}
-3 & -2 & -1 & 0 & +1 & +2 & +3 \\
\hline UNSAFE & MUCH LESS A LITTLE & NO & A LITTLE & MUCH MORE VERY \\
& SAFE & LESS SAFE AFFECT & MORE SAFE & SAFE & SAFE
\end{tabular}


9) What do you think is the probability of this happening again? (Cirlce one)

\begin{tabular}{clrlll}
-3 & -2 & -1 & +1 & +2 & +3 \\
\hline \multirow{2}{*}{ NEVER } & VERY & SOMEWHAT & SOMEWHAT & VERY & DEFINATELY \\
& UNLIKELY & UNLIKELY & LIKELY & LIKELY & WILL HAPPEN
\end{tabular}

10) Sometimes when people read about a murder case they say "at least it's understandable", and sometimes they will say "it was a senseless murder". Which category would you put this murder in?

11) On a scale of 1 to 10 , where would you rate this case on: Horribleness ( 10 is most horrible) Bizarreness ( 10 is most bizarre)

12) What do you think is the single most frightening thing about this event? (Again, say anything you really mean. Please think carefully and say the first thing that occurs to you.) 
The Manson Case

In August 1969, Los Angeles experienced two consecutive nights of murder. The murderers were all members of a commune near Los Angeles, and were all in their late teens or early twenties. The commune was lead by a 34 year old male ex-convict.

On the first night, five people were variously shot and stabbed to death in the Bel Aire home of one of the victims, an actress, who was pregnant at the time. Small amounts of money were stolen. 'PIG' was written on the front door in blood. One male and three females were at the scene that night, one of the females did not participate in the murders. The leader of the commune, who was not among the murderers, reportedly planned the murders and told the others to commit them.

on the second night, a man and his wife were killed in their home near Griffith Park. On this night, the leader of the commune went into the house with one other male. They bound the victims. After leaving, the male and one of the females from the previous night, accompanied by another female entered the house. They stabbed the couple to death. 'DEATH TO PIGS' and 'RISE' were written on the wall in blood and 'HEALTER SKELTER' was written on the refrigerator, also in blood. 'WAR' was carved on the man's stomach and a carving fork was found protruding from his stomach. A bag of coins and some credit cards were stolen.

They were arrested in December of 1969 and charged 
with the murders. The prosecution maintained that this had been done to start a race war as a part of a plan set forth by the leader. All the murderers and the leader were found guilty of murder and conspiracy to commit murder.

\section{The Sal Mineo Case}

On the night of February 13, 1976, in Los Angeles, California, an actor was returning home from a play rehearsal. As he got out of his car, he was confronted by a long haired man dressed in dark clothing. Neighbors heard the man shout. A friend and neighbor ran to the garage. The actor was lying on the floor in a pool of blood. He had several stab wounds in his chest. The friend tried to revive him, but the wounds were fatal, having penetrated the heart.

Though there was speculation, police were unable to solve the murder of this man, a two-time Academy Award nominee. In May 1977, more than a year after the murder, police received a call from a woman. She claimed that her husband had admitted the killing to her after returning home the night of the murder, covered with blood. She said the weapon had been a cheap hunting knife and that the murder was the result of an argument over drugs.

The police doubted the account. There was no recorded history of drugs in the life of the victim. Also, her husband had been arrested for robbery shortly after the murder and had offered to provide information about the murder 
in return for leniency.

Further investigation made the twenty two year old black man look like a more likely suspect. It was found that a knife of the type described by the woman had been used in the murder. When they located the man, he was in a Michigan prison for writing bad checks. Authorities said that he had repeatedly bragged about having committed the murder while in custody.

He was eventually brought back to Los Angeles and tried in January of 1979. He was found guilty.

\section{The Norma Jean Armistead Case}

In 0ctober 1974 an obstetrical nurse who was working at a major Los Angeles hospital created a 'paper pregnancy' for herself. She did this by filing the appropriate records at the hospital. Some people found a pregnancy at age 44 unusual, but not unusual enough to cause serious suspicions.

During her fake pregnancy she used her position to locate a genuinely pregnant woman. On the night of May 15, 1975, she paid a visit to a 28 year old unmarried mother-tobe. Both women were supposediy due to deliver at any time. On this night, the nurse cut the other woman's throat. She then performed a skillful Caesarean section, removing the nearly full-term baby.

She then bundled up the infant and went to a hospital where she was admitted as a patient. She claimed to have given birth to the baby at home. It wasn't long before it 
was determined not to be the case. She was arrested and later convicted.

The Robert Benjamin Smith Case

On November 12, 1966, an eighteen year old high school student, with a good school record, entered a beauty shop in Mesa, Arizona. He was armed with a pistol and a knife. He ordered the people in the shop to lie on the floor forming the spokes of a wheel, with their heads in the center. The five women and two children did as they were told. He then shot each of the victims in the head. One woman rose and attempted to attack the boy. He stabbed her to death.

He calmly walked outside as the police arrived. One of the policemen asked what was happening inside. He answered "I've just killed all the women in there." He was arrested. He later told reporters, "I wanted to get known, just wanted to get myself a name." He was later convicted.

The Alday Family Murder Case

In May 1973, three men escaped from a minimal security corrections camp in Maryland. Two of the men were brothers serving time for robbery and burglary respectively. The third was an older black man serving time for nonpayment of child support. They contacted a third brother, a 15 year old, and he went with them. The four of them abducted a college student, killed him, buried him in a shallow grave and drove to Georgia in his car.

They broke into a trailer house in rural seminole 
County, Georigia. It was on the 500 acre farm of a prominent family who basically 'was' the town. One of the five brothers of this farm family resided in the trailer house with his wife. No one was at home when the intruders broke in intending to rob it. They were interrupted by members of the family as they arrived, one by one, for a weekly business meeting. As they arrived, they were lead into different rooms and shot through the head, this fate met the father and four of the brothers. After shooting the men, they each beat, raped and sodomized the woman who lived in the trailer with her (now dead) husband. They dragged her out to the car where the older man raped her. He then took her into the woods, where he shot her twice in the back, killing her.

They took the woman's car, leaving the car they had taken from the college student. They drove through three states. They held up a store in Virginia, but they didn't kill anyone else. They were finally captured by police. They were tried and convicted.

\section{The Gertrude Wright Baniszewski Case}

In July 1965, in Indianapolis, Indiana, a 16 year old girl and her 15 year old sister came to live with a 36 year old woman and her 7 children who ranged in age from an infant to 18. They were to stay there while their parents followed the carnival circuit, running a concession stand. The father was often late sending the money he had 
promised the woman for keeping the girls. The girls were beaten for this. The woman came to vent her anger only on, the older girl. The beatings became more frequent and severe. She encouraged her children and children from the neighborhood to participate. They forced her to dance naked while making derisive remarks, put her in a bath hot enough to peel skin, put cigarettes out on her body, pushed her down stairs, and beat her repeatedly.

After a few months the girl was no longer allowed to leave the house. "I am a prostitute and proud of it" was branded on her stomach with a heated needle by the woman and one of the boys, while the others watched. She was kept in the basement, naked and often bound. She was branded with a branding iron, starved, forced to drink urine and eat feces, and beaten further.

On October 26, 1965 , police received a call from two of the children. They said the girl had come home badly beaten after leaving with a group of boys who raped her and beat her. There was a note to this effect in the girl's writing, it had been extracted from her sometime earlier. As police were about to leave, the girl's sister said she would tell the whole story if they would take her with them.

The woman and several of the teenagers were arrested. They were tried and convicted.

The Dean Corll Case

On August 8, 1973, Houston, Texas police received a 
phone call stating: "Listen, you better come on over. I killed a guy." Police were greeted by three teenagers when they arrived, two boys and a girl. They found a 33 year old man, who had been shot. He was in a room that was bare except for a table, manacles on a board on the wall, a large plastic sheet covering the floor, a radio with extra batteries and a print of Jesus captioned LOVE.

One of the boys told police that the older man had been furious that a girl had been brought to their party. He seemed to calm down. They smoked marijuana, drank beer, and the teenagers inhaled the fumes from acrylic paint until they passed out. When they regained consciousness, the boy was handcuffed to the board on the wall, and the others were bound and lying on the floor. He persuaded the man to release him to help with the rape, torture and murder of the others. Once released, he managed to get the gun off of the table and fired all six bullets into the man.

He went on to tell the police that he and another youth (who was not there that night) had routinely furnished the man with young victims. They would invite them to parties and when they passed out, manacle them to the wall. After the victims regained consciousness, the man, sometimes with the help of one or both of the boys, would rape, torture and eventually murder the victim, with the radio turned up to drown out the screams. They then buried the body in one of a few places, the most common being a boathouse rented for that purpose. Police found 27 bodies of boys 
between the ages of 13 and 18 , many had been castrated. More may have been left unfound. There was no coordinated investigation into the disappearances of these boys at the time the call came in about the man being shot.

The two boys were arrested. The one was found guilty of 6 murders, but not in the case of shooting the man, that was ruled to be self defense. The other boy was found guilty of one count of murder.

\section{The John Linley Frazier Case}

On October 19, 1970, in Santa Cruz, California, firemen responded to a report that the home of a prominent surgeon was on fire. When they arrived, the doctor's red Rolls Royce was blocking the drive. A typewritten note was under the windshield wiper, it read:

halloween....1970

today world war 3 will begin as brought to you by the pepole of the free universe From this day forward any one and ?/or company of persons who missuses the natural enviornment or destroys same will suffer the penelty of death by the people of the free universe.

I and my comrads from this day forth will fight until death or freedom, against anything or anyone who dose not support natural life on this planet, materialism must die or man-kind will.

$\begin{array}{lll}\text { KNIGHT } & \text { OF } & \text { WANDS } \\ \text { KNIGHT } & \text { OF } & \text { CUPS } \\ \text { KNIGHT } & \text { OF } & \text { PENTICLES } \\ \text { KNIGHT } & \text { OF } & \text { SWORDS }\end{array}$

The bodies of the doctor, his wife, their two young sons and the doctor's secretary were found by the firemen. They had each been bound, shot, and thrown into the pool. 
Fires were set throughout the lavish home.

The murderer was a 24 year old man who was living, off and on, in a cow shed near the doctor's home, and next to the killer's mother's trailer house. He incorporated various occult and mystical systems and his feelings about pollution and materialism into a belief system which was reinforced by direct messages he received from God. Acquaintances of the murderer who knew of his beliefs called the police after the murders, relating their suspicions and saying that the man had gone off into the woods. Four days later, police found him asleep in the cow shed and arrested him. He was convicted.

The Douglas Gretzler and William Steelman Case

In late 1973 , a 28 year old male, ex-mental patient and another man, 22 years old, bound and gagged their two partners in a drug deal and put them in the back of their van. They drove from Phoenix, Arizona, to a trailer house in Apache Junction. There they killed the man and woman who occupied the trailer with shotgun blasts at close range to the head.

They drove to California where they stripped their drug dealing partners, strangling one and cutting the throat of the other. At that point, they drove back to Phoenix, picking up two hitchhikers and killing them both. They drove from Phoenix to Tucson, where they broke into an apartment shooting the young couple who lived there. They drove 
the couples car to California.

In Victor, California, they broke into a house, holding an 18 year old girl, her boyfriend and the two young children they were watching, at gunpoint. When the parents and three of their friends returned, one of the intruders went with the man of the couple to get $\$ 4,000$ from a safe at his store. At some point, all seven adults were tied, gagged and put in a large, walk-in closet. Each of the victims were shot once in the chest and once in the head. The aduits were found in the closet, the children were in their beds.

The two men were captured shortly after this. Each was tried repeatedly in various places, being repeatedly found guilty.

The Marlene 0live Case

In June 1975, in San Rafael, California, police responded to a call from a man worried about his business partner who had missed meetings and not answered his calls. When police reached the residence they found only the 16 year old adopted daughter of the couple. Her answers were vague and contradictory. She was taken in for further questioning, but released.

The girl claimed to have magical powers, and convinced her friends of this. Most of this was concentrated on a 20 year old, 260 pound, male outcast. He wore a bracelet she gave him which she said gave her power over him, he 
believed it.

She demonstrated her control by having him shoplift for her, commanding him to perform sexual acts, with her or her friends, sometimes for others, sometimes for a camera. She also carved her initials in his back.

The family had moved there from South America, which meant a drastic change in their finances, and the company their daughter kept. Fights between the girl and her mother increased in frequency and violence. When the girl began to get into trouble with the authorities, the mother threatened to send her to a school for delinquent girls, and obtained a court order requiring her to stop seeing the boy.

The girl began to form plans to have her mother killed, and pressuring her boyfriend to help. When it became a certainty that she would be sent away, she called the boy and told him to get a gun and come to the house. He entered the house after the girl and her father left. The mother was battered to death with a claw hammer. When the father and daughter returned, the father saw what had happened and lunged at the boy with a knife. The boy shot him four times. They wrapped the bodies in blankets, soaked them in gasoline, took them to a park, and set them on fire in a barbeque pit. They crushed the remaining bones. All that was found was a few bone chips and a few teeth, as a result of an anonymous call.

The days between the murders and the arrest were filled with drugs, sex and plans for the inheritance. Both 
were tried and found guilty.

\section{The Zebra Case}

In San Francisco, in a 179-day period in late 1973 and early 1974, twenty three people were assaulted on the streets. Fifteen of these people died. All the victims were white. The assailants were five black men, all were members of a secret extremist sect of the Black Muslims. They were led in secret meetings by a black man from chicago, who is thought to have been the leader of several such groups, primarily in California. He flew in for many of the meetings, delivering impassioned sermons and encouragement when the other men carried out his ideas as he saw fit.

The men were all attempting to become Death Angels. To attain this rank, they had to kill nine white men, or five white women, or four white children. They brought pictures of their victims or other forms of proof to the meetings. If they had 'done well' they received praise from the leader and the same (tainted with jealousy) from the others, if they had 'done poorly' they received the contempt of all.

A couple was assaulted with a machete, the woman was decapitated, the man survived. One woman was raped. A man was abducted, taken to the secret meeting place, and held, bound and gagged, naked, for a day before he was hacked to death by all the members of the group, taking turns. His body was dismembered, formed into the shape of a frozen turkey, wrapped in plastic and a yellow net made of rope, 
and thrown into the bay on Thanksgiving Day. The remainder of the victims were shot at close range, with one of two guns. Most frequently the murderers would go out in groups of two or three, encouraging each other to commit these acts. On a few occasions they acted arone.

They were all arrested after one of the men informed the police of the identity of all the men. A few of the other members of this sect who were present at the murder of the abducted man in the meeting place were initially arrested, but let go. The leader was not arrested. The informer was not indicted, the other four men were tried and convicted.

\section{The Sandra Beam Murder Case}

On the evening of January 7, 1976, in St. Joesph, Missouri, a two day party began. In attendance were four women, ages 18 to 25 , and several men who came and left during the course of the party. Large quantities of beer, wine, gin, vodka and marijuana were consumed.

At some point, three of the girls developed an increasing hostility toward the fourth girl, apparently stemming from relationships she had had with black men. They forced the victim to consume successive glasses of gin and vodka. When she became $i 11$, they grabbed her hair and poured more liquor laced with shampoo and silver polish down her throat. In the next 44 hours, they cut off portions of her hair, beat her, put her in a tub of cold water and rammed a bar of soap in her mouth, shaved her pubic hair, put paint and nai 1 
polish on her body, and used rubbing alcohol as a douche, pouring the remainder down her throat.

All this time, various men came and went. While none of them participated, none of them helped the girl either. One of the men tied the unconscious victim to a chair and removed sharp objects from the room, in case she 'came to violent'.

The police received a phone call from one of the women saying that 'something happened'. The three women were arrested and tried, none of the men stood trial. Two were found guilty of second degree murder, the third was found guilty of manslaughter.

\section{The Frederick Cowan Case}

On February 14, 1977, in New Rochelle, New York, a 33 year old man drove to a moving company, his place of employment. After slipping bandoliers of ammunition over his shoulders and around his waist, putting four pistols in his belt and snapping two grenades to his pockets, he took an automatic rifle with a telescopic sight and entered the building.

The man was a 250 pound weight lifter, with a passion for weaponry and Nazi ideology. His room was filled with Nazi memorabillia and literature and a sizeable collection of weapons. His arms were covered with tattoos of swastikas and skulls. He inscribed "Nothing is lower than blacks and Jews except the police who protect them" on the fly leaf of 
one of his books about Hitler.

He entered the building looking for his boss who is Jewish. Not finding him, he shot two black co-workers. He went to the cafeteria looking for his boss, not finding him, he shot another man. He shot another black man on the stairs as he went to the second floor. His boss crawled out from under his desk and called the police. A police car came to the scene. One officer was shot to death shortly after emerging from the car, his partner was shot in the leg trying to help him. The police surrounded the building. They established contact with the killer, to no avail. When the murderer mentioned grenades, an armored tank was brought in. They waited for an opportunity to capture the man. Seven hours after he entered the building, a single shot was heard. The murderer was found dead, having shot himself in the head. 
APPENDIX B

THE MANSON SURVEY

This questionnaire is part of a thesis being done by a graduate student in the Psychology Department. While your help would be greatly appreciated, participation in this study is completely voluntary. Non-participation will not affect your grade in class. If you decide not to complete this form, please return it before leaving. It will take approximately half an hour to complete. Your response will remain anonymous. If you have any questions or want to talk to someone, contact the person administering this questionnaire.

If you have answered a questionnaire on a similar topic, please indicate:

In what class

Who was the instructor

What was the questionnaire about

If you have answered this questionnaire before, please put a check on this 1 ine and return the form 


\author{
IMPORTANT \\ PLEASE DO THIS INDEPENDENTLY \\ DO NOT TALK TO ANYONE UNTIL YOU ARE FINISHED \\ DO NOT PUT YOUR NAME ON THIS PAPER \\ YOUR ANSWERS WILL BE ANONYMOUS
}

Please finish this section before going on. Once you have begun the second section, please do not go back to the first section. The sections are separated by a colored sheet of paper.

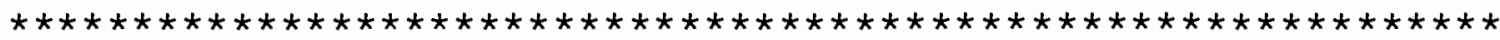

Your age $\operatorname{Sex}$ National origin

Where have you lived most of your life? (City, State/ Country)

For most of your life since age 16? (City, State/Country)

Please write down everything you know about Charles Manson. Write a short sentence or phrase on each 1 ine, expressing one thought. Write each thing in the order that it occurs to you--write the first thing you think of on the first line, the second thing you think of on the second line, etc. There are no right or wrong answers, this is to find out what people actually know or have heard about Charles Manson. Thanks for helping. 
1) Where did you learn what you know about Charles Manson? (Check all that apply)

Newspapers Radio TV Magazines Word of Mouth Other (Please specify)

2) Why do you think the Manson event happened? Please say anything you believe.

3) Do you know of anyone who was associated with charles Manson in any way? Yes No If yes, please specify who, when and where in each case.

4) Do you think Charles Manson should be paroled? (Circle one )

\begin{tabular}{llccclc}
-3 & -2 & -1 & 0 & +1 & +2 & +3 \\
\hline NEVER & STRONGLY & MILDLY & INDIF- & MILDLY & STRONGLY & RELEASE \\
RELEASE & OPPOSE & OPPOSE & FERENT & FAVOR & FAVOR & AT ONCE \\
& RELEASE & RELEASE & & RELEASE & RELEASE &
\end{tabular}

5) If you know anything about his associates, do you think they should be paroled? (Circle one)

\begin{tabular}{llccclc}
-3 & -2 & -1 & 0 & +1 & +2 & +3 \\
\hline NEVER & STRONGLY & MILDLY & INDIF & MILDLY & STRONGLY & RELEASE \\
RELEASE & OPPOSE & OPPOSE & FERENT & FAVOR & FAVOR & AT ONCE \\
& RELEASE & RELEASE & & RELEASE & RELEASE &
\end{tabular}

6) What do you think should have happened to Charles Manson after being convicted? (You may say anything you really mean, your answer is anonymous.)

7) What do you think should have happened to his associates after conviction?

8) Do you feel that Charles Manson is crazy? Yes No Unsure 
9) Do you feel that his associates are crazy?

Yes No Unsure

10) How does this event affect your feeling of safety? (Circle one)

$-3$
$-2$ $-1$ $+1$ $+2$ $+3$

UNSAFE MUCH LESS A LITTLE NO A LITTLE MUCH MORE VERY SAFE LESS SAFE AFFECT MORE SAFE SAFE SAFE

11) What do you feel is the probability of this happening again? (Circle one) $-3$ $-1$ $+1$ $+2$ $+3$

NEVER VERY SOMEWHAT SOMEWHAT VERY DEFINATELY UNLIKELY UNLIKELY LIKELY LIKELY WILL HAPPEN

12) Sometimes when people read about a murder case they will say "at least it's understandable" and sometimes they will say "it was a senseless murder". Which category would you put this murder in?

Understandable Senseless

13) On a scale of 1 to 10 , where would you rate this incident on:

$$
\begin{aligned}
& \text { Horribleness ( } 10 \text { is most horrible) } \\
& \text { Bizarreness ( } 10 \text { is most bizarre) }
\end{aligned}
$$

14) At what age did you become aware of the news to the extent that you were aware of most current events? (Reading the newspaper, watching TV news regularly, discussing current events, etc.)

15) What do you feel is the single most frightening thing about this event? (Again, say anything you really mean. 
Please think carefully and say the first thing that occurs to you.) 


\section{MASS MURDER SURVEY}

This questionnaire is part of a thesis being done by a graduate student in the Psychology Department. While your help would be greatly appreciated, participation in this study is completely voluntary. Non-participation will not affect your grade in class. If you decide not to complete this form, please return it before leaving. This questionnaire deals with the subject of murder. If you find this distressing, you need not answer this questionnaire. It will take approximately half an hour to complete. Your response will remain anonymous. If you have any questions or want to talk to someone, contact the person administering this questionnaire.

If you have answered a questionnaire on a similar topic, please indicate:

In what class

Who was the instructor

What was the questionnaire about

If you have answered this questionnaire before, please put a check on this line and return the form 
IMPORTANT

PLEASE DO THIS INDEPENDENTLY

DO NOT TALK TO ANYONE UNTIL YOU ARE FINISHED

DO NOT PUT YOUR NAME ON THIS PAPER

YOUR ANSWERS WILL BE ANONYMOUS

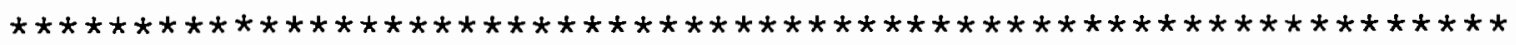

Please finish this section before going on. Once you have begun the second section, please do not go back to the first section. The sections are separated by a colored sheet of paper.

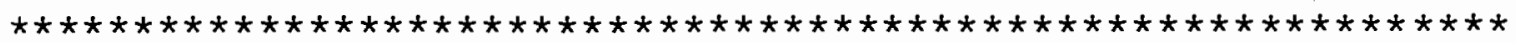

Your age

$\operatorname{Sex}$

National Origin

Where have you lived most of your life? (City, State)

Country)

For most of your life since age 16 ?

(City, State/Country)

Please write down every incident of mass murder you know of, in the order that it occurs to you. Give as much information as you can which might help us to identify the incident, such as: Names of murderers, names of victims, names given to the murderer or the case by the press, approximate dates, where the murders occurred, method of killing, or patterns of victims. You don't have to give all this information about any one incident, any information about any incident will be helpful. There are no right or wrong answers, this is to 
find out what people actually know or have heard about mass murder.

For the purposes of this questionnaire we will be using the term mass murder as it is popularly used. This definition is: The murder of a number of people on one occasion, or the murder of one or more people on each of a number of successive occasions by the same murderer or murderers.

Please separate each incident you write about from the next by drawing a line between them. After each incident, please indicate where you learned of that particular incident-Newspapers, radio, TV, word of mouth, books, other (please specify). Thanks for helping. 
We are interested in determining when the taking of human life becomes mass murder. We are also interested in determining under what circumstances the killing of a number of people is generally considered to be mass murder. All of the following questions are a matter of opinion. There are no right or wrong answers. We want to know what you think about the following situations.

1) When more than one person is murdered on the same occasion, how many people must be killed before it is mass murder? _ people

2) If a murderer kills more than once, how many times must the murderer kill before it is mass murder? times

3) If a large number of people are murdered by the same person, is it mass murder if the victims are related to the murderer?

Yes

No Sometimes If sometimes, when? How do such cases affect your feelings of safety? (Check one)

No affect A little less safe Much less safe Unsafe In general, do you feel such murderers are crazy? (Check one) Yes_ No___ Unsure _ _ Would you classify this sort of murder as: Understandable Senseless

(Note: this set of questions followed questions $3-13$ on the 
original survey. In the interest of space, they will be deleted from this point on.)

4) If a person repeatedly kills in the course of armed robbery, is it mass murder?

5) If a person repeatedly kills in the course of rape, is it mass murder?

6) If a large number of military personnel are killed by a government during a war, is it mass murder?

7) If a large number of civilians are killed by a government during a war, is it mass murder?

8) If a large number of military personnel are killed by a government not at war, is it mass murder?

9) If a large number of civilians are killed by a government not at war, is it mass murder?

10) If a large number of people are killed by organized criminals, is it mass murder?

11) If a large number of people are killed as a result of terrorist activity, is it mass murder?

12) If a large number of people are killed as a result of gang conflicts, is it mass murder?

13) If a large number of people are killed by a hired killer, is it mass murder? 
APPENDIX D

RECOGNITION POLL

IMPORTANT

PLEASE DO THIS INDEPENDENTLY

DO NOT TALK TO ANYONE UNTIL YOU ARE FINISHED

DO NOT PUT YOUR NAME ON THIS PAPER

YOUR ANSWERS WILL BE ANONYMOUS

This is part of a thesis being done by a graduate student in the Psychology Department. While your help would be greatly appreciated, participation in this study is completely voluntary. Non-participation will not affect your grade in class. This questionnaire will take approximately 20 minutes to complete. Your responses will remain anonymous. If you decide not to complete this form, return the blank questionnaire.

Your age Sex National Origin

Where have you lived most of your 1 ife? (City, State) Country)

For most of your life since age 16? (City, State/Country) 
short statement about that item:

Jack Nicholson actor

Ronald Reagan politician, president, actor

Kitty Genovese killed in N.Y. as many watched, none helped

James Beard chef, writer

Woodstock music festival in N.Y. in the 60's

A) Capone gangster

You may not recognize many of the items, don't let this bother you. If you don't recognize an item, just go on to the next item. Thank you for your help.

Sal Mineo

Lesley Gore

Robert Macnamara

Jacquel in Susann

Judith Crist

Marlene 01 ive John Dean

Susan Atkins

Elmer Wayne Henley Jr.

Pete Athens

Sandra Beam

Charlie Scott

Carol Parker

Anwar Sadat

Dean Cor 11 
Ry Cooder

Clive Barnes

Mimi Garrard

Steven Parent

Billy Isacs

Morris Udahl

Leslie Van Houten

Carl Isaacs

Bill Blass

J.C. Simons

Charles Watson

Manuel Moore

or. Ohta

Leno Labianca

Hubert Humphrey

John Linely Frazier

Roy Orbison

Gertrude Baniszewski

Barbara Ann Cockran

Jay Sebring

William Westmoreland

Cyrus Vance

Stanley Kubrick

George Dungee

Patricia Krenwinkle

Peter Schaffer

Watergate 
Frank Church

Sharon Tate

Wayne Coleman

Klaus Barbie

Frederick Cowan

Janis Joplin

Charles Manson

Robert Benjamin Smith

Jesse Cooke

Adele Erb Sullivan

Golda Meir

Rosemary Labianca

Donald C. Alexander

Earl warren

Sam Erwin

Doug Gretzler

Joesph A. Yablonski

Sonny Terry

Anne Klein

Zebra

Larry Green

Marshall Tito

David Sackson

Rosemary Woods

Carol Vadnais

Vidal Sassoon

Voytek Frykowski 
Sylvia Likens

Charlie Tickner

Billie Jean King

Timothy Leary

Roosevelt Boule

Norman Vincent Peel

David Owen Brooks

Lorna Luft

Lionel Ray Williams

John Lindsay

Neil Simon

Abigail Folger

Walter Kapryn

Draft Lottery

Peter Cook

Gloria Thomas

Elvin Bishop

Charles David Riley

Jack Ruby

Yippies

Arnold Palmer

Buzz Aldrin

William Steelman

Andy Warhol

Henry Mancini

George Romney

Norma Jean Armistead 
My Lai

Richard A, Roth

Erica Jong

Anthony Harris

Mel Brooks

Bruce Lee

Willard Wirtz

Johnny Carson

Clare Luce Booth 


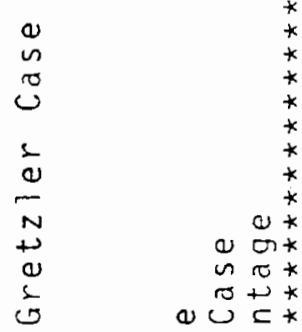

$\infty$ a n $\begin{array}{lllll}a & 0 & 0 & 0 & 0 \\ *\end{array}$

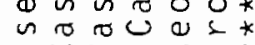
Er山U $E 0 *$

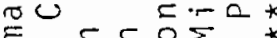
$\equiv 0+\pi \omega^{2}-k$ $\alpha>-\pi=\pi$

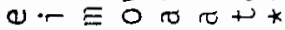

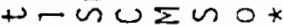
ก 0 os os 1 Q $Q \leq \leq \leq \leq *$

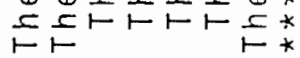

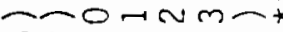
$\infty$ on $\rightarrow \rightarrow-x$ $m$ ma

N) $n$

$\rightarrow$ m $\infty$

$\because ! 0_{-1}^{0}$

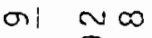

or

$\infty 1 \underbrace{0}_{-1} 0$

$N Q^{\circ}$

() $\bigodot_{-1}^{0} 0$

n) $\infty \infty$

$+1 \infty \infty$

m) $\sim \infty$

on

N) $\infty_{\infty}^{\infty}$

$-1 \underbrace{0}_{-1} 0$

$1, \infty \sim$

$\infty-$

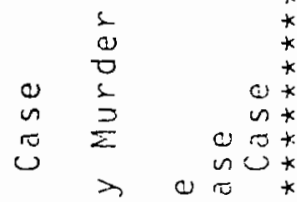

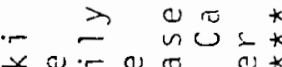
$x \omega=0 \quad n=0$

$\sum \pi \bar{\sigma} \pi \quad+*$

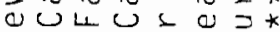

$N \cup L \cup \frac{1}{0} \cup$

un $\rightarrow r . r$ n $*$

$-1 \sigma-N \cdot \sigma E *$

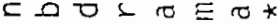

$00-01 \leq 0+$

DNaUL< $<0 *$

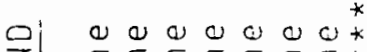

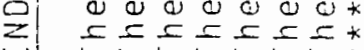

0 -

w
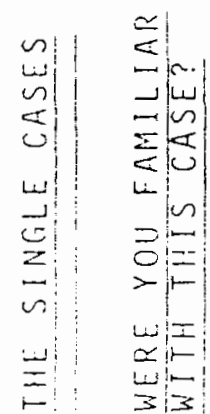

$0 \%$

20 $\sim \infty$

$00000 \%$

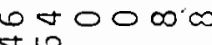

mo

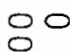

- $0 \underset{4}{0} \infty 00$

00

$\underset{\sim}{\sim} \operatorname{mon}_{N}$

$\circ$

$\stackrel{0}{0}$

n $\infty \mathrm{m}^{\mathrm{m}}$

00

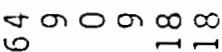

$\circ 0$

$\infty \ln _{\pi}^{\infty} 0$

$\underset{0}{0}$

n 00000

00

moo 00

0

nm

0

$\rightarrow \circ \infty \infty \circ \sigma$

w

$\stackrel{\circ}{\circ}$

0

n)

$\stackrel{\circ}{w}$

똥ㅇㅇㅇㅛ

$\stackrel{0}{0}$

เก เก

onTRNG

$0 m \infty 000$

anoror

$m \rightarrow-1$

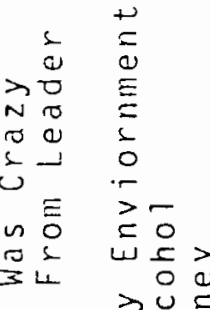

\& a $\square-0$

$0 \leqslant \leqslant<$

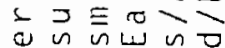

$\backsim \cdot$.

ร $4 \cup 0=0$

I $50<1$

$=a \simeq \infty \frac{1}{0}$ 
nl 00000000000000 a 0000000000000000000

$+10000000000000000000000000000000000$ ml no00000n

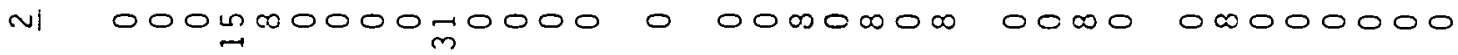
- N N H! $\begin{array}{lll}1 & n & \frac{5}{0} \\ 0 & 0 & 0\end{array}$

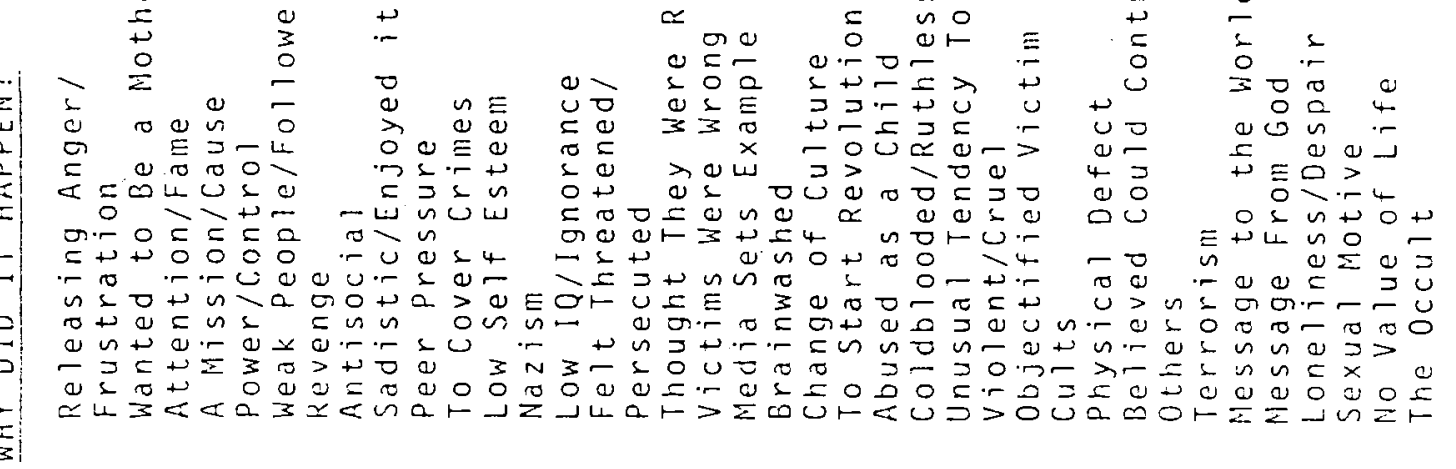


m

N 000000000

न1 000000000

O1 00000000

al 0 क 0000000

$\infty 1$ a 00000000

Mo

0! 000000000

n) 000000000

+1 00000000

mi o o 0000000

N 000000000

$-10000=0000$

$\vdash 1$

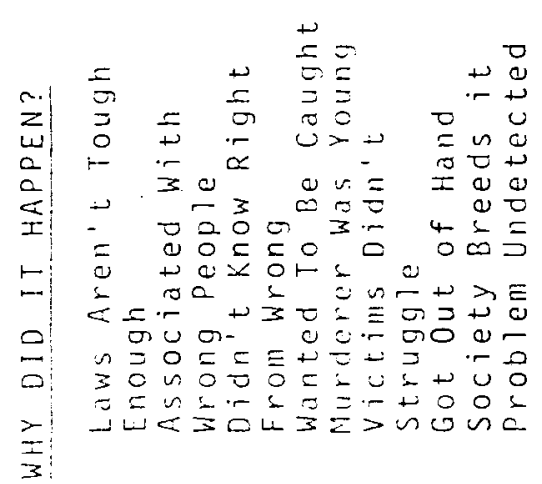

nin mom

$\infty 00000$

$\sin \infty 000$

LN NOOOO

$n \rightarrow$

ᄂก

$\sim \infty 0000$ $\infty \rightarrow$

in

$\infty$ in $\infty 000$ Ln

minotoo

$\infty$ L $\infty 00 \infty$ in

mon

$+\rightarrow \infty 000$

$\sin =0$

$\sim \sim \infty \backsim \neg-$ $\sim m$

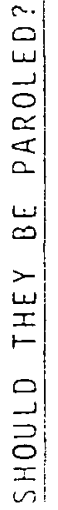

$m \infty n 000 \infty 0$ $\vec{m} \infty 00 m i n$ On $\stackrel{m}{\sim} \vec{m}^{\infty} \infty \infty$ ñ ᄂ

I OOñ⿻

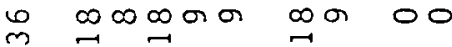
$\because 0 m 0$ on 00 I $\infty \mathrm{m}_{\mathrm{m}} 0$ oo in $\infty \infty 000$ $0 \infty$ on nomoon na n nmono no non n mominum no no

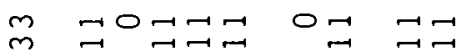
m moncon $\infty \infty \infty \omega$

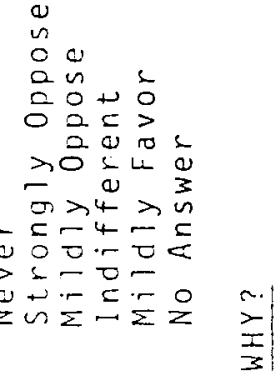

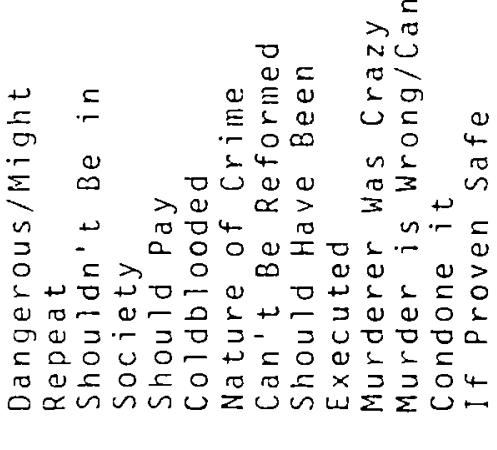


m 00000000000000000000

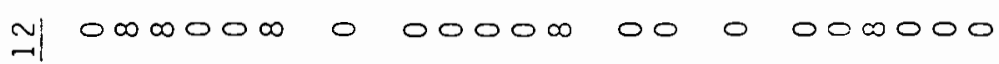

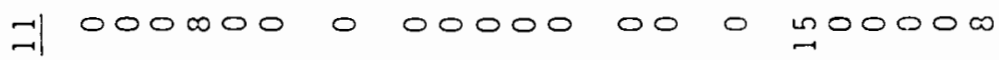

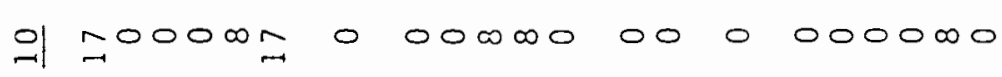

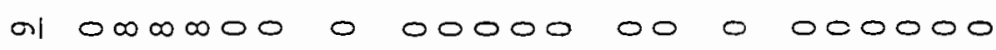

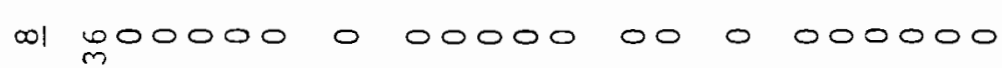

$-100000000000000000000$

0100000000000000000000

LI 0000000000000000000

$+0000000000000000000$

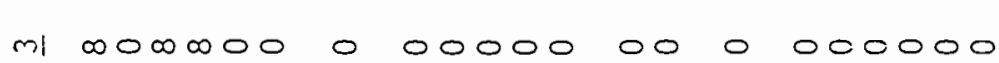

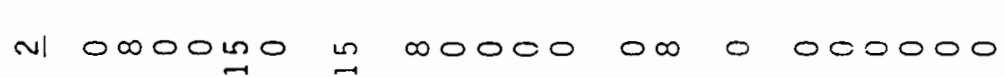

$+100070000000070000000$

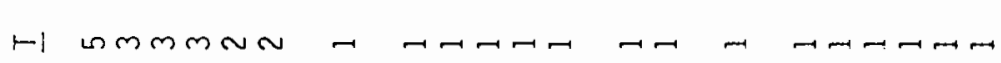

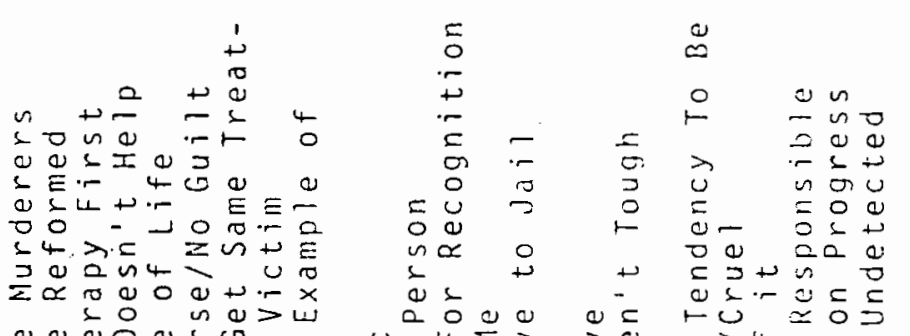

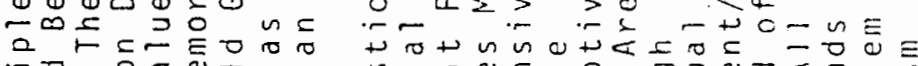

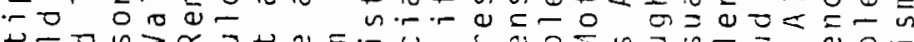
Шラ

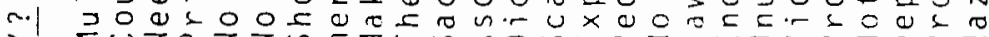

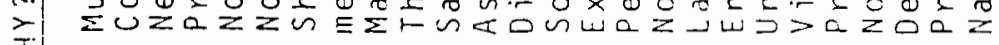

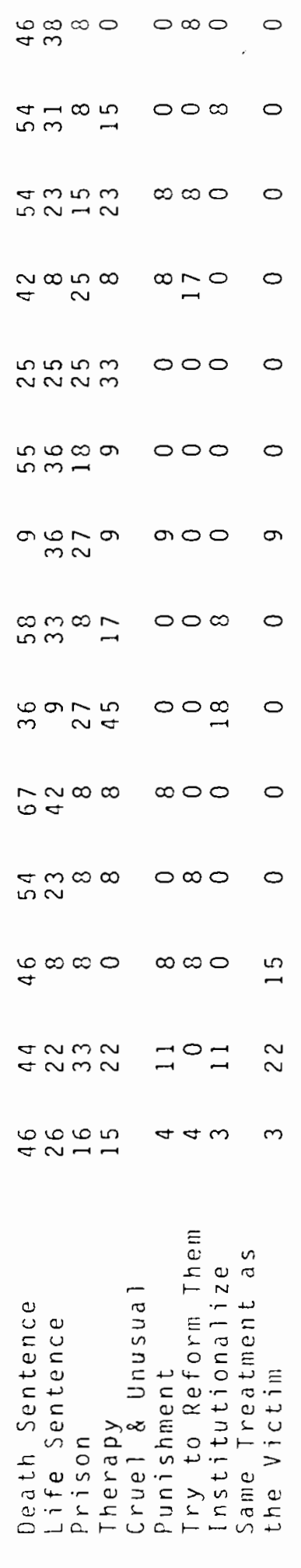

$\underset{m \infty}{0 \infty} \infty 0 \infty 0$

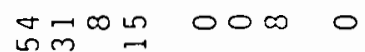
$\ln m \infty \infty \infty \infty \infty$
$\underset{\sim}{\sim \infty} \infty \ln ^{\infty} \infty$

nL $\ln$ m 0000

nूm

mono aco a

$\lim _{n \rightarrow \infty} 00 \infty 0$

mañ $00 \%$

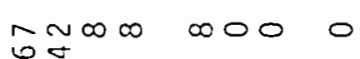

$\approx+m \infty \infty \quad \nabla \infty 00$ 


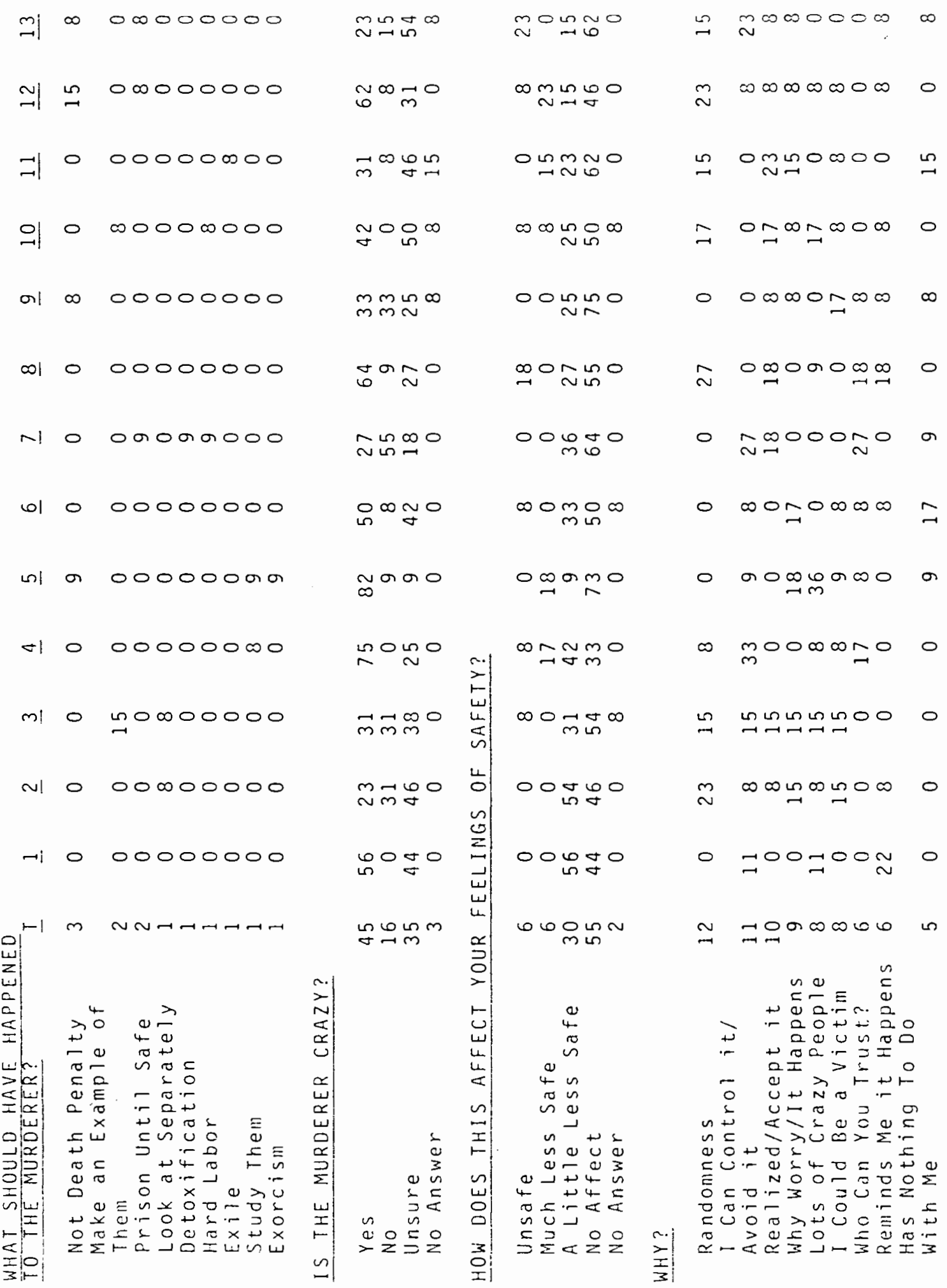




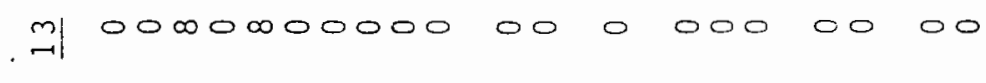

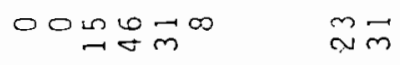

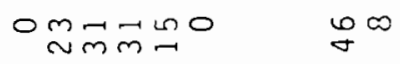

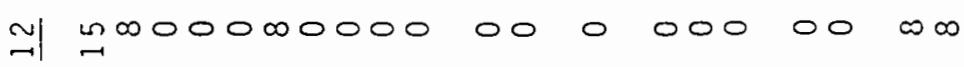

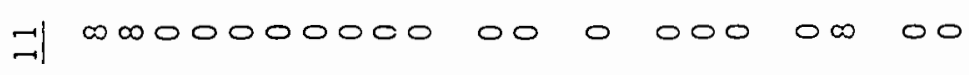

wongmo mm

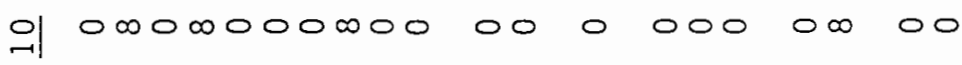

$0 \infty \approx n \rightarrow m o$

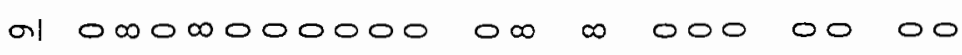

miñ⿻

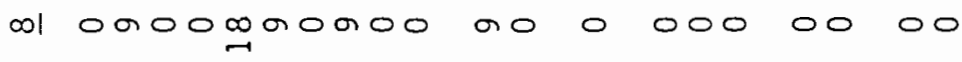

Oaño

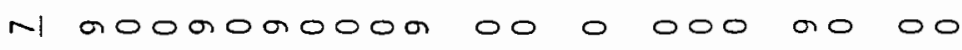

aromon

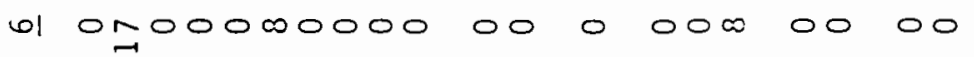

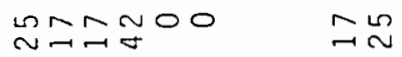

는

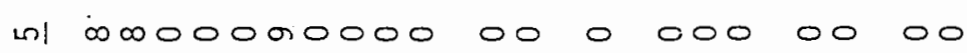

$0 \lim 00$

$\approx m$

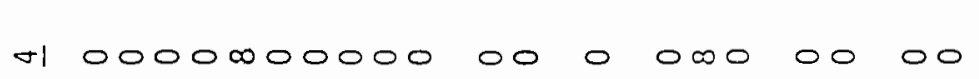

0
2
2
5
5

m| 0000000000000000000

$\stackrel{x}{2}$

NI 00 no

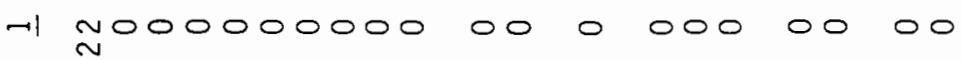

$00 \operatorname{lin}_{\ln } \ln 0$

$\bigcap_{10}^{\infty}$

$\infty \infty \infty \underset{\omega}{\infty} \infty \quad \stackrel{\sim}{\sim}$

$\min \infty \infty_{m}^{\infty} \quad \infty \vec{m}$

ornmmo $\rightarrow \mathrm{mm}$

$\exists \approx$

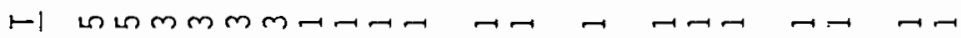

$\omega \stackrel{\sim}{\sim} \quad 0 \quad \pm$

$\pi \rightarrow \infty 6-$

잉

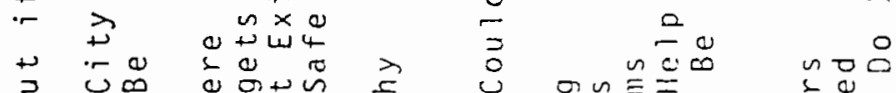

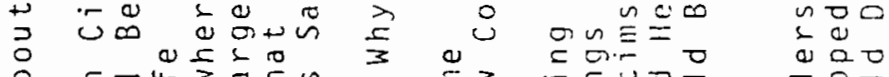

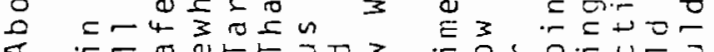

$<\cdot \div$ i n a r

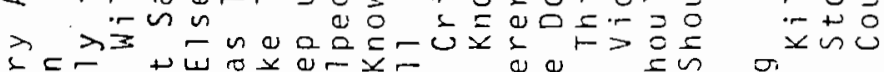

ᄂ

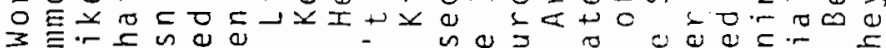

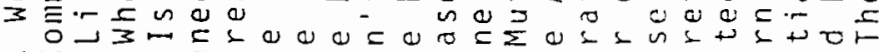
+U

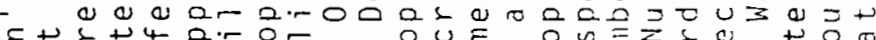

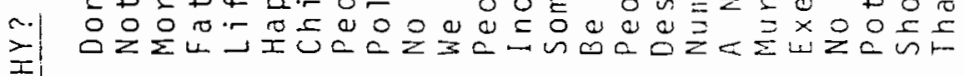




\begin{tabular}{|c|c|c|c|c|c|c|}
\hline$m$ & 0000000000 & o & 0 & $\infty 00000000000000$ & $\circ$ & $\stackrel{\sim}{\sigma} \vec{m}$ \\
\hline 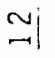 & 0000000000 & 0 & 0 & 0000000000001000 & 0 & $\stackrel{n}{\sim} \infty$ \\
\hline 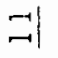 & $\infty \infty \infty 0 \infty 00000$ & 0 & $\infty$ & 000000000000000 & 0 & $\sim_{n}^{\infty} \infty$ \\
\hline o) & $\bar{a} \infty 00000000$ & 0 & $\circ$ & 000000000000000 & $\infty$ & $\stackrel{n}{\sim} \ln ^{\infty}$ \\
\hline ol & $\infty \infty 000 \infty 0000$ & 0 & 0 & 000000000000000 & 0 & $\underset{m}{N} \sim$ \\
\hline$\infty \mid$ & a 000000000 & $\sigma$ & 0 & a000000000000000 & 0 & $\underset{\infty}{\infty} \stackrel{\infty}{\longrightarrow}$ \\
\hline-1 & $000000 \mathrm{~mol}$ & 0 & 0 & 000000000000000 & 0 & $\vec{\sigma} 0 \sigma$ \\
\hline$\omega$ & 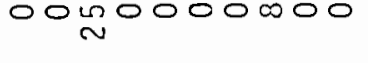 & $\infty$ & 0 & 000000000000000 & 0 & $m=0$ \\
\hline (I) & $\underset{\pi}{\infty} 000000000$ & 0 & or & 000000000000000 & 0 & $\stackrel{m \infty}{n}$ \\
\hline$\infty 1$ & INOONO0000 & 0 & $\infty$ & 1000000000000000 & 0 & $m \infty 0$ \\
\hline mi & 1000000000 & $\infty$ & 0 & 000000000000000 & 0 & $\begin{array}{ll}N \sim m \\
0 \sim N\end{array}$ \\
\hline N! & 2000000000 & 0 & 0 & $\infty 0000000 \ln 100000$ & 0 & $\ln _{0} \infty$ \\
\hline-1 & 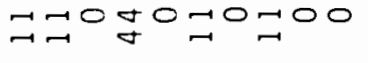 & 0 & 0 & 000000000007000 & 0 & ๒ேニ \\
\hline$r-1$ & $\sigma \backsim m m m m m \sim N$ & $\sim$ & $N$ & 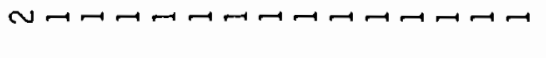 & $\rightarrow$ & $\underset{r a m}{\sigma}$ \\
\hline
\end{tabular}

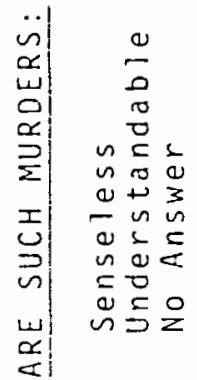


$m$ mmono00

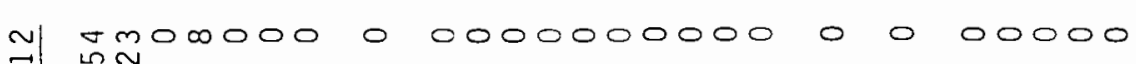

$m \sim \infty \sim \infty$

$\rightarrow \ln \sim$

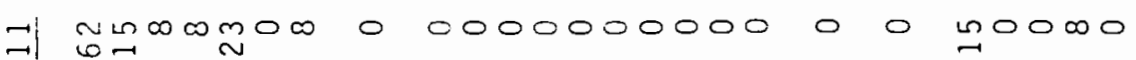

$\rightarrow \infty \infty 0$

$\underset{m \sim m}{\infty}$

이 $\infty 000000000000000000000000$

$\ln =\infty 0$

a) $\sim \infty 00000$ w 00000000000000000

$\underset{\sim}{\sim} \infty \infty 0$

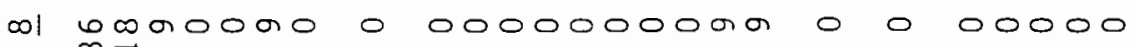

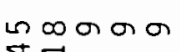

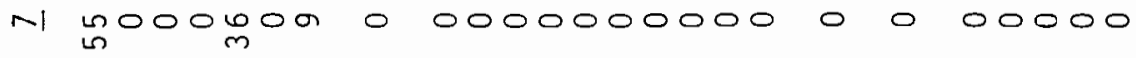

$\ln 6 \pi 0$

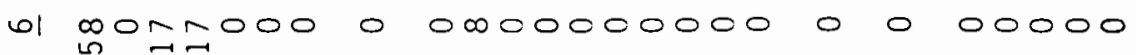

$\underset{\sim}{\sim} \infty \infty$

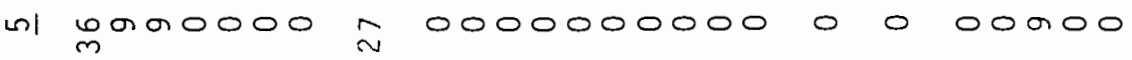

ம $\infty \pi \sigma$

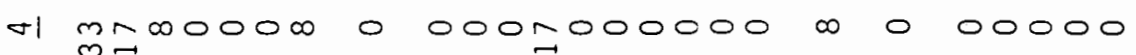

m|

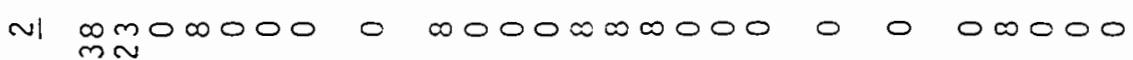

$\pi$ a

ワ1

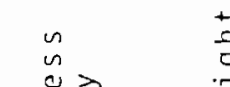

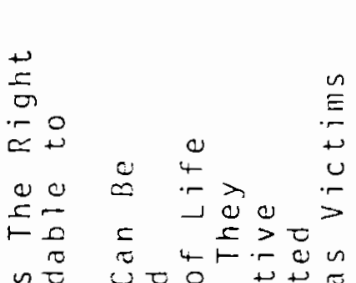

$0-\stackrel{N}{0}$

$>00$

$-\pi$ a

$\pm=0$

$\because 0$

$\simeq+$
$E 00$
$E \leq-0$

$\sum \sim$

$\omega, \frac{0}{\square}$

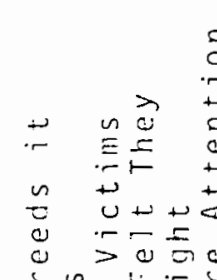

$\begin{array}{ll}5 & 0 \\ 5 & 0 \\ 0 & 0 \\ +1 & 0\end{array}$

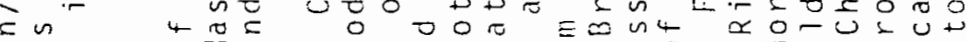

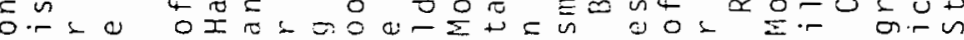

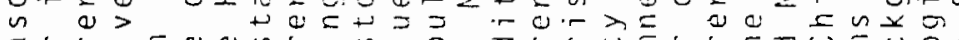

rots

a d

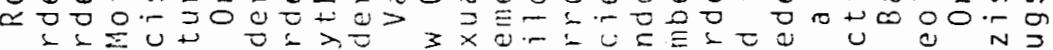

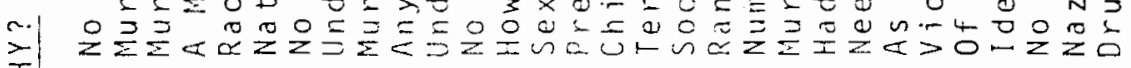

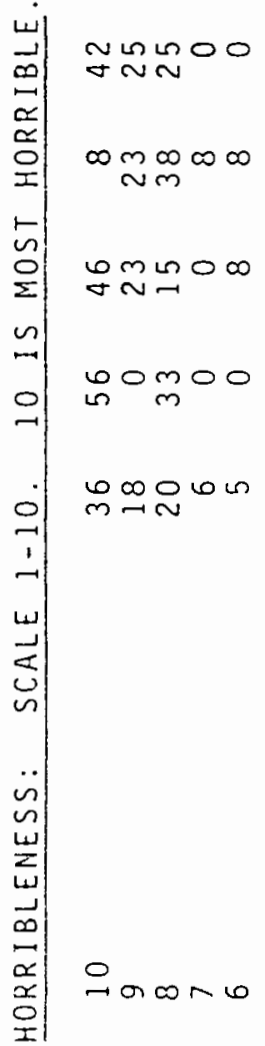




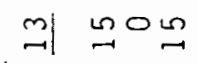
$\because$ noo minmo000000L

I) $\infty \infty \infty$

$\stackrel{01}{01} 00$

al $\underset{\sim}{\sim} 0$

$\infty$ on 00

$-1000$

$\infty 1 \infty 00$

늘

(n)

$+100 \infty$

$w$

立

N) 000

$\rightarrow 00=$

$\mapsto 1 \sim r$

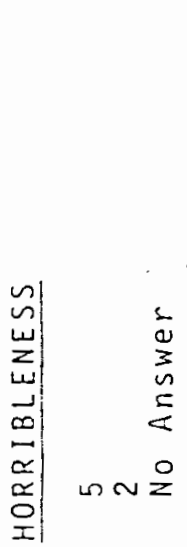

$\infty 00 m 0000: 00$

OOMm nNm

$\sim \infty \pi \sim \infty 000000$

monOONODOON

$\sigma \infty \infty 00000000$

wantanomon

$m$

$m$ m N $\infty 000000$

momorarooro

$u$
0
0
5
0
0
5
0
$\frac{0}{2}$

mintadoo0000 $\sim \sim \rightarrow \rightarrow$

O以n

nimong nomon

Don 00000000000 mog $\sim 00 m \sim G r i n$

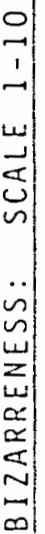

$w$
$\omega$
$\vdots$

$\infty$ on 0000000000000

n vomoroloo an ano i OOONODANOO OO ONO

$\vec{m} \infty \infty 00 \pi 0 \infty \infty \infty \infty 00000$

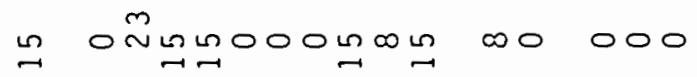
$\exists$ चनच

$\circ$ OOONம -19

a $\simeq \sim$

- $\quad E \quad$ o

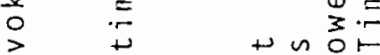

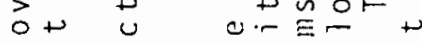

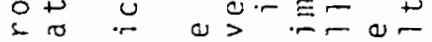

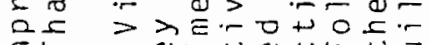

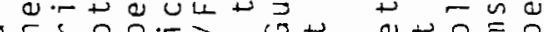
암

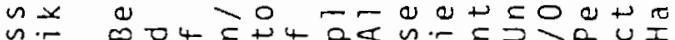
n. $004 \leq+40<$ ñ

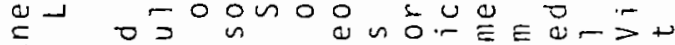

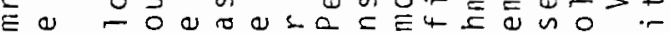

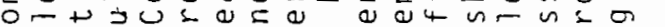

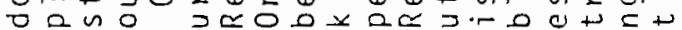

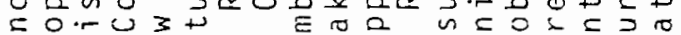

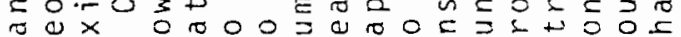

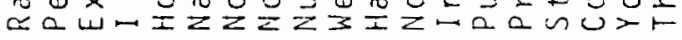


$m 0000000000000000000000000000$

$\underset{1}{N 1} 000000000000000000000000000$

$\Rightarrow 000$ I 000000000000000000000000

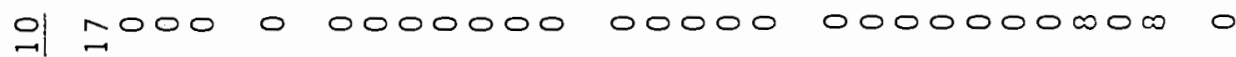

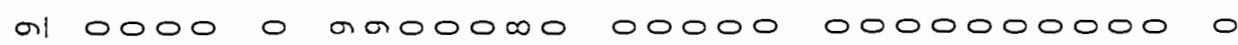

$\infty 10000000000000000000000000000$

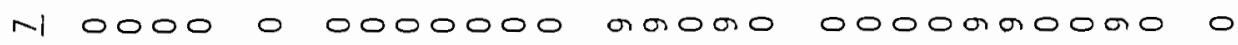

W 0000 क 00000000000000000000000

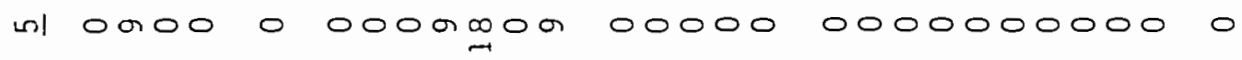

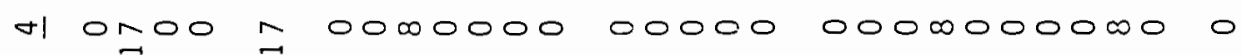

mi 0000000000000000000000000000

NI 00000000000000000 m0n00000000

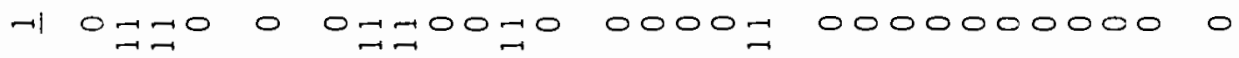

H mmmo $\sim$ N

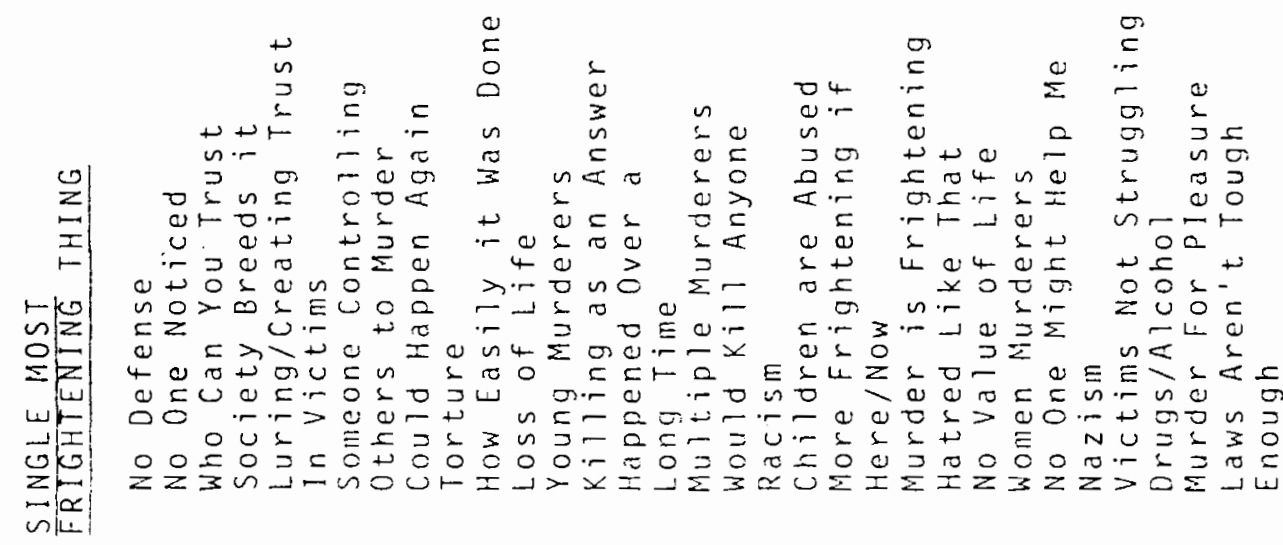


$m \ln _{n}$ min

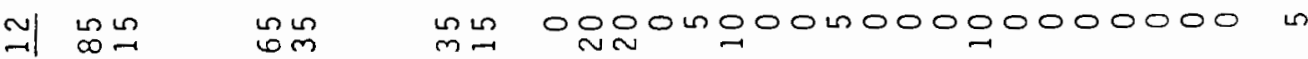

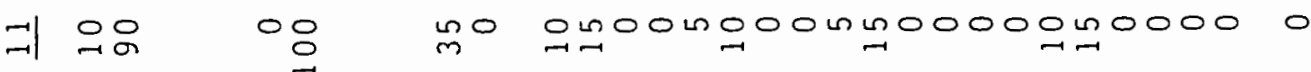

$\begin{array}{llll}0 & 0 & 0 & 0 \\ 0 & 0 & 0 & 0\end{array}$

al 00 0 00 nL 000001000000000000000

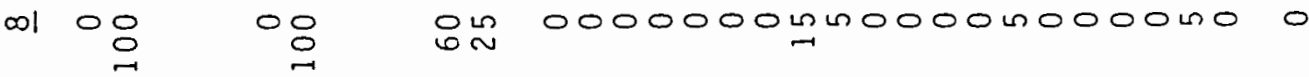

$M \quad 08$ O O O O

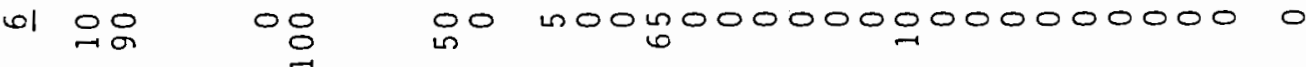

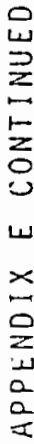

LI Ln L

$\odot \bigcirc$

no nono0000m000000000000

O) 20

Oo no $00 m 00 n 00000 n 00 n 00000 \mathrm{n}$

mi nu

00

mo

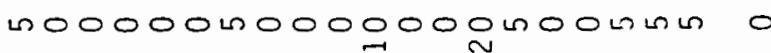

N 00

$0 \varnothing$

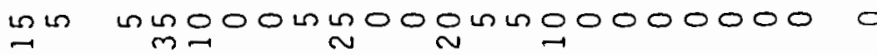

$-100$

00

in $\ln _{\mathrm{N}} 000100000000000000$

$-1 N \infty$

6

$\sum_{m \rightarrow-1} 0$
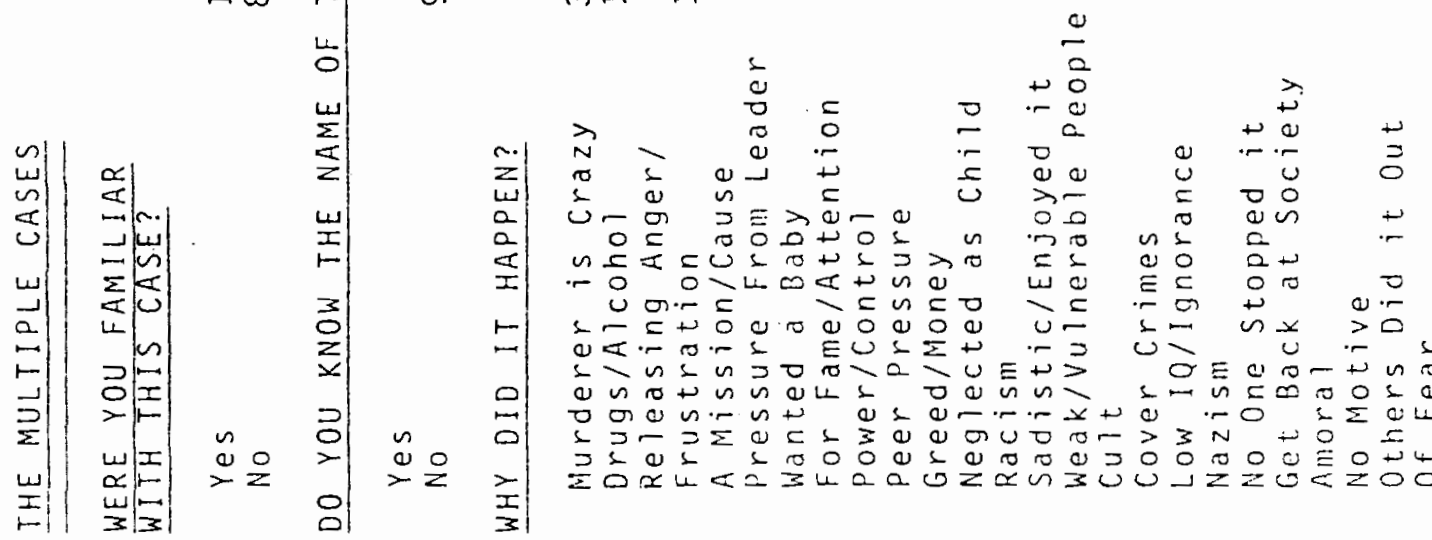
$m 000000000$

$m \quad 0 \quad 00000000$

$\Rightarrow 00000000$

0.100000000

0! 000000000

$\infty 1 \quad 0$ not

N 000000000

w 000000000

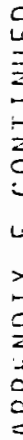

ni 000000000

बI 000000000

m $00000 \mathrm{LO} 00$

N10000 0000

$-1000000000$

レ1 ナ ナーーーーーーー $\infty$

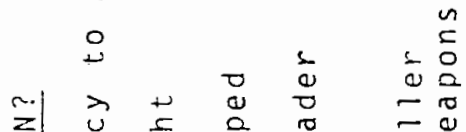

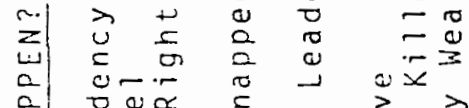

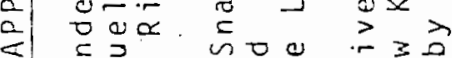

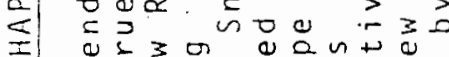
过芯它

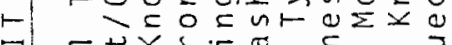
-4 0)

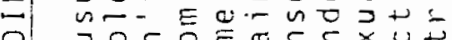

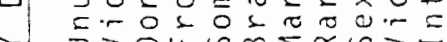

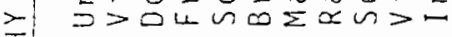
$m \in H$

in mong

n $\ln 0000$ Ln $m$

$\operatorname{lng}$ $n \min$
$m$

000000 $\ln 0 \ln 2 \ln 0$

o OnO LnO m엥

nOm

in 000100

$\operatorname{DO}_{\mathrm{m}} 0000$

on $\ln 000$ $6 \mathrm{~m}$

On

N $\sim m m \rightarrow$ in

in

000

nิ

बढं

$-\infty \frac{0}{2} \pi$

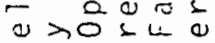
$\therefore \rightarrow 00 \frac{0}{3}$ $a>4 \geqslant n$ a 0 0. $>1-0-$ $\alpha \omega r=50$

$z \ln \Sigma \Sigma z$
nOOL OOD nONO

moO nO nO

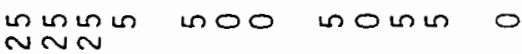

OMnO nOL unino

nmol 000 nomo

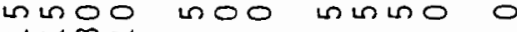

nog noO

ningm nino notnomo

nonin mom onmono

ninom noon 00000 mung nun o num n minum not no $\ln _{i=1}$ minn w $N \rightarrow-1$ $\stackrel{0}{\infty}$

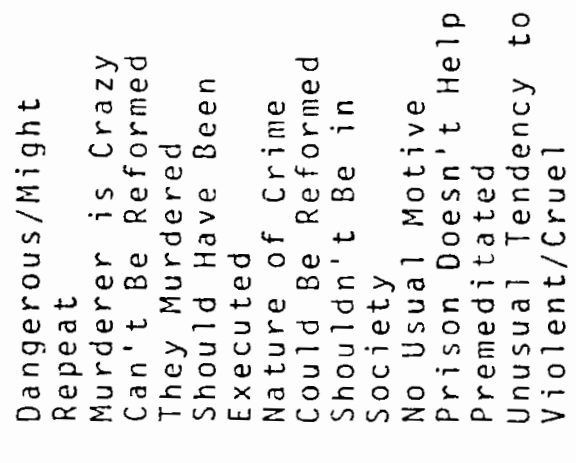




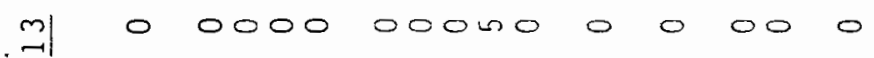

N 0 nomo 00000 w 0 or

$\Rightarrow 000000000 \mathrm{~L} 00000$

이 000000000000000

al n 0000000000000

$\infty 1000000000000$

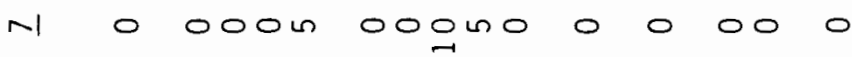

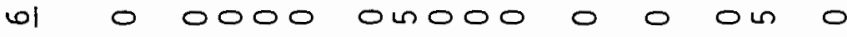



nl 000000000000000

ol m 0000 noO0L 0 mo no

ml o ninom 0000000000

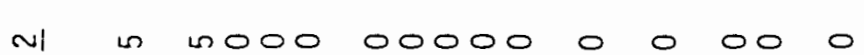

$-1000000000000000$

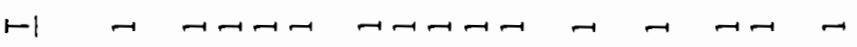

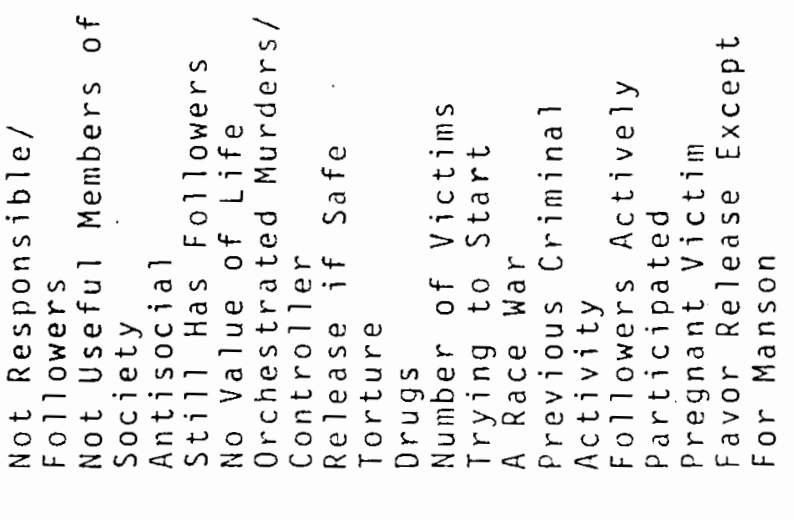

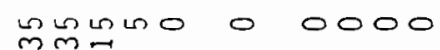

Oomono o

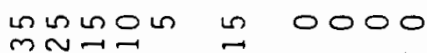

mmior

$\operatorname{lnmin} \min$ in noto

ondm in 0000

imninin o

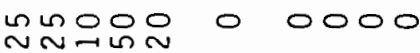

ondong o 0000

Nmmon in
Nm

w nomoo n

n $\rightarrow m \rightarrow$

onomo on nomo

mnnom nn OñO

$\operatorname{\sigma n} \infty \infty$ in $N \rightarrow \rightarrow$ $m \sim N \rightarrow \infty$ 


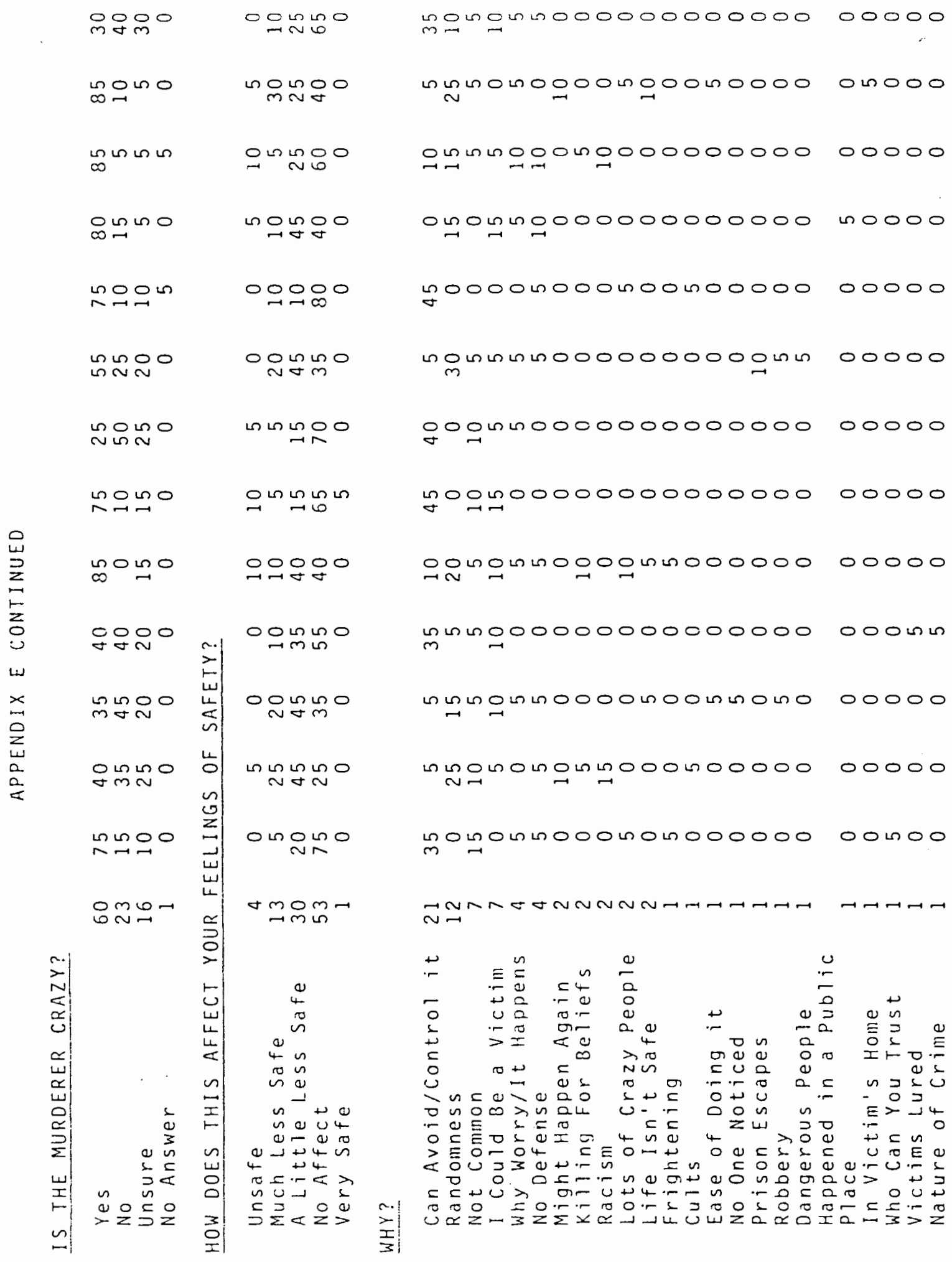




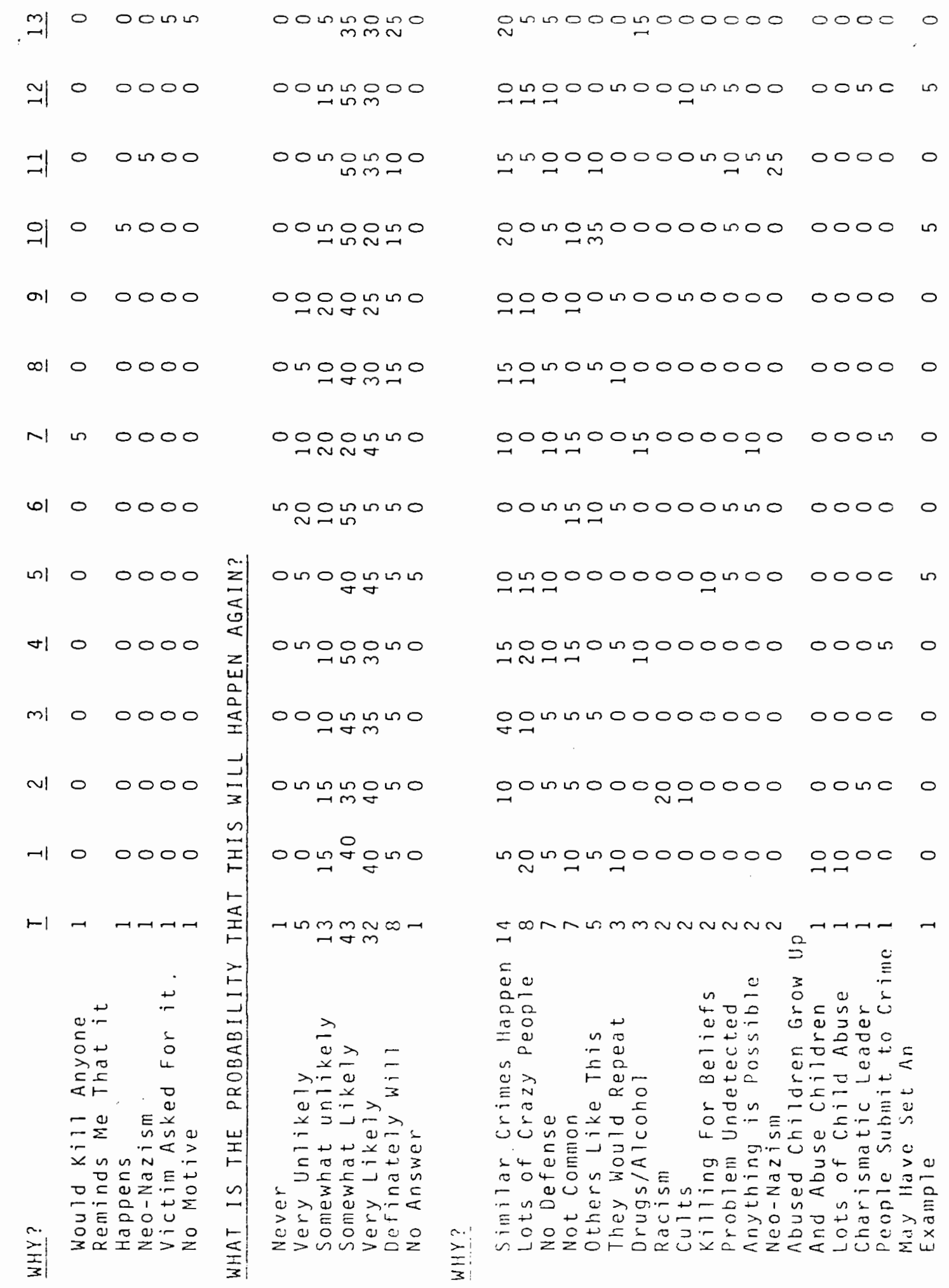


$m$ N 000 on 0010

$\Rightarrow$ no 00000

이잉 000000

al 00 no000

$\infty 100000$

M no 100000

(1) 0000000

nl 0000000

$\nabla 0000000$

mlon 00000

NI 00 onomo

$-10000000$

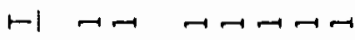

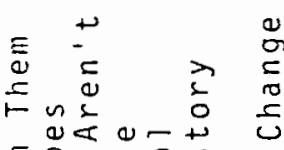

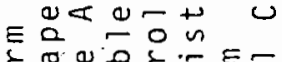

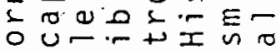

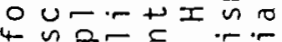

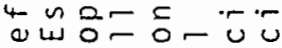
$\propto$ व

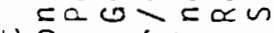
$+0, \alpha+2=n$ $\varepsilon \cdot \pi \backsim \pi \frac{0}{3}=n$ n ¿ U⿺辶一兀 $\ln 2 \ln 0$

ᄋ̊

000

$\infty$

$\operatorname{lo}_{\infty} \stackrel{0}{\sim}$

nin

$\infty \rightarrow$

on in

$n \mathrm{~m}$
10

$\infty_{0 \rightarrow \infty}^{0} 0$

nino

$6 \mathrm{~m}$

nᄂ $\cos$

or

in ino

$\ln _{0} 0$ in

$n m-$

$\infty-$

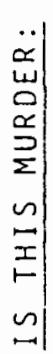

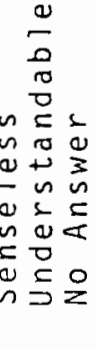

nolomomoo oom 00000000 molnmolnom ono 00000000 gunmomón omo 00000000

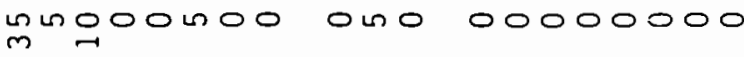

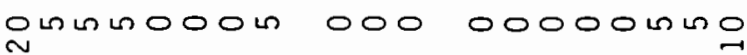
monnonor Oninomodo on Ominominom no onmomoog nino 00000000 mLnLmLon

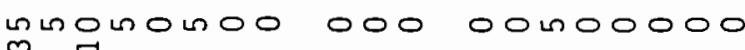

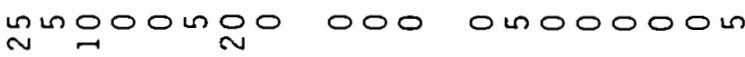

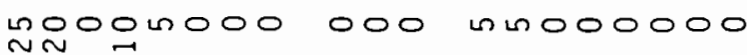

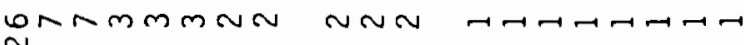
N

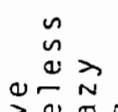

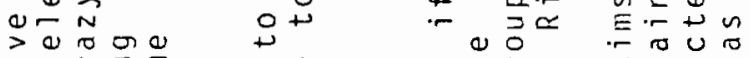

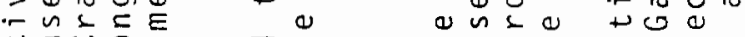

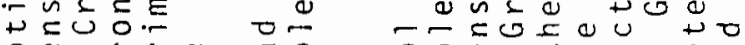

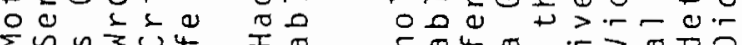

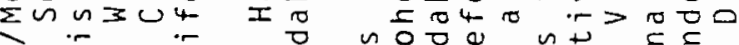
En nu. $r$, n

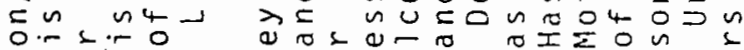
n 0 4

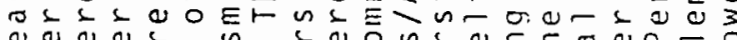

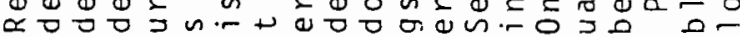

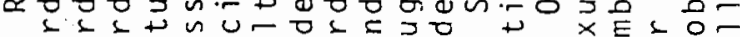

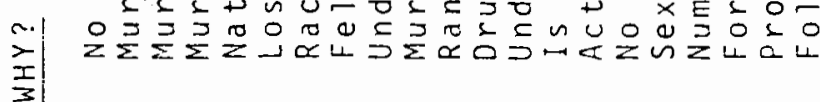


$m: 0000$

N1 0000

$\Rightarrow$ nomo

이 0000

ol $000 \mathrm{~m}$

$\infty 10000$

$\sim 0000$

(o) 0 noo

(n) 0000

$+10000$

m) 0000

N 0000

$-10000$

トレナーヤー

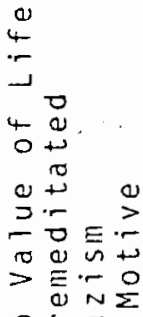

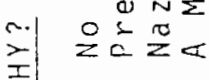

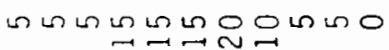

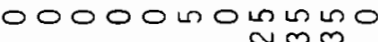

o OOnO o omoningomin

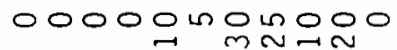

o 0000 mingmo

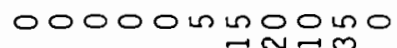

o 00 on

o o o m monmón

w) 000000 nomoo

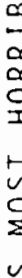

0
$\Sigma$
$n$

odonomoningo

m N

o 00000 num non

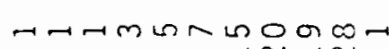

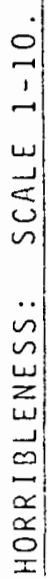

- minnm nom

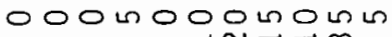
$\rightarrow N \rightarrow \rightarrow m$

on o dningonom o dom unenging onLmingmodom O OnOLOOLLIN nodoningniming

o dnumonom nom o 0000 mognin

(1)

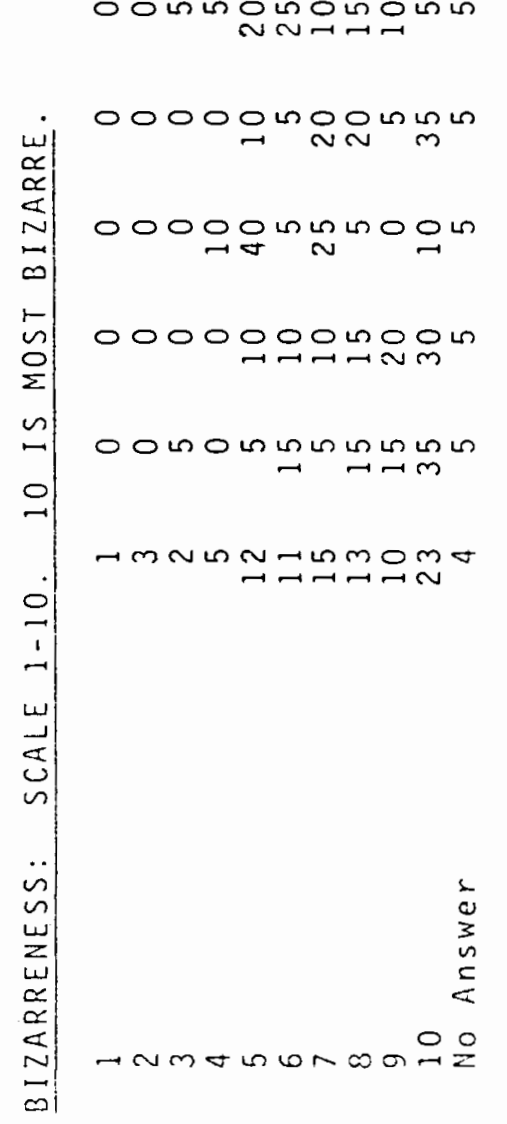

no 00

0000

no 00

o

0,100

o d in

$0_{0} 000$

जi 000 n

$n$

o o in o

$\exists$ no 000

oono

00no Somo

ก

$\frac{n}{1}$

$\because 3+$

$-\div=$

Q $0=$

에

잉 ज +00 의 ज这造 oc。 山 $0 \equiv$ 등응욤 $0=$ ○ण $23 \times 2$ 
m o

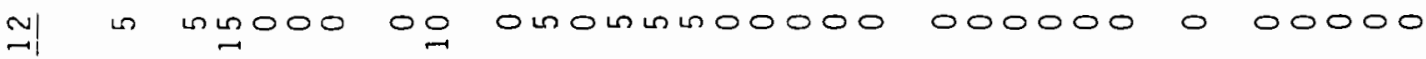

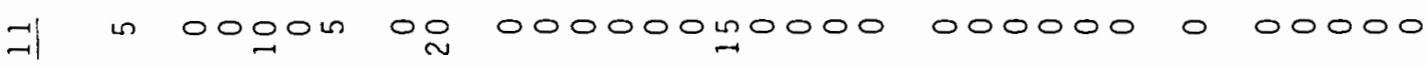

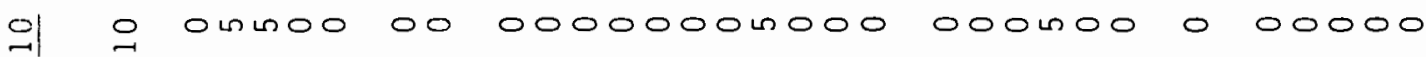

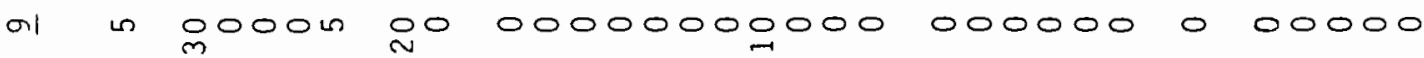

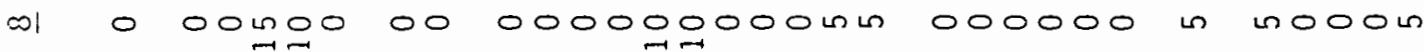

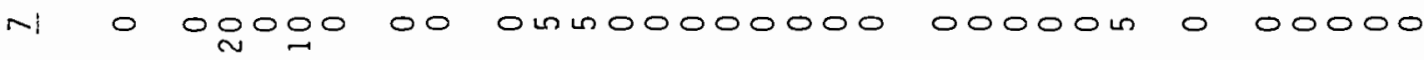

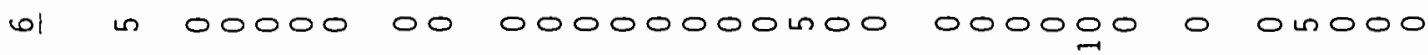

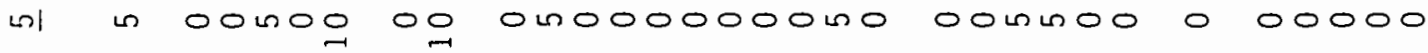

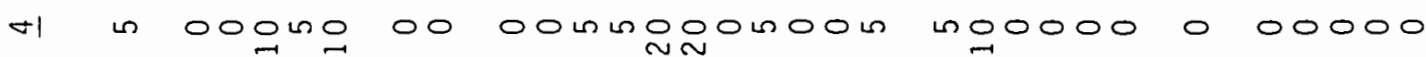

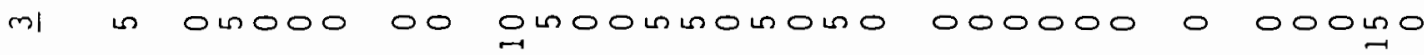

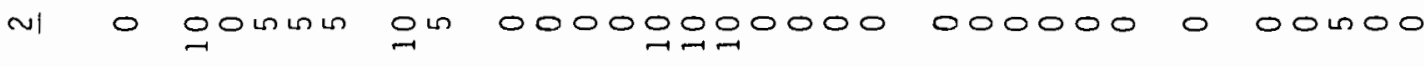

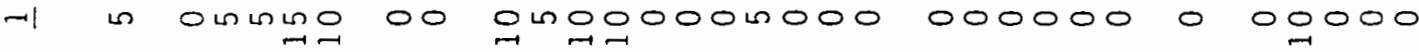

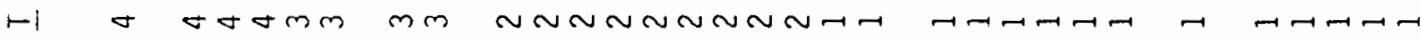

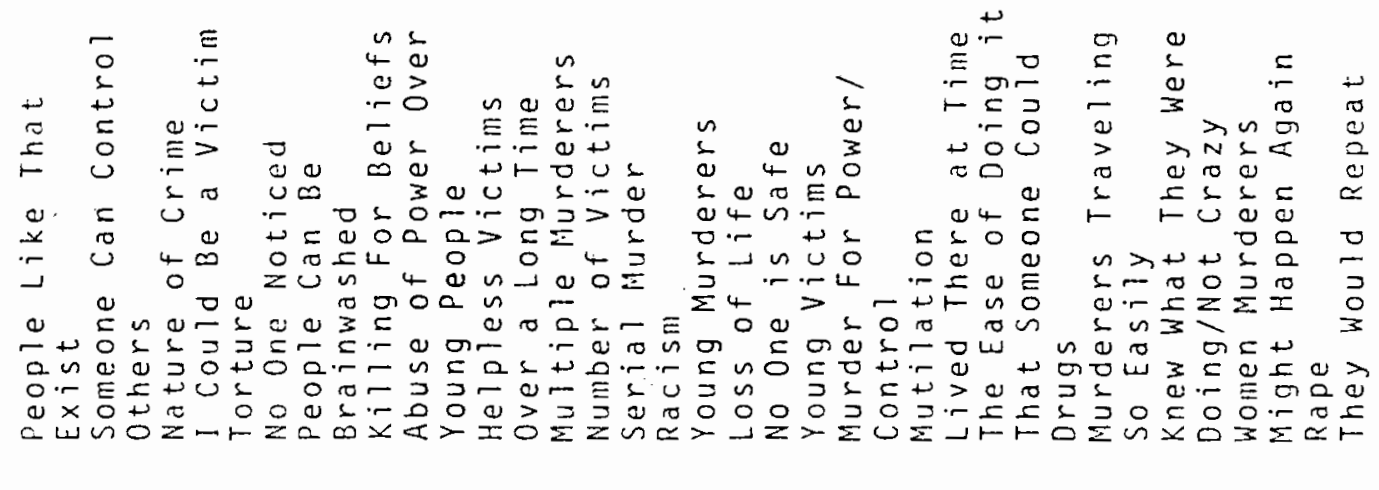


m 00000000000000

N 00 Non 0000 mo

$\Rightarrow \quad 00$ L

이 00000000000000

al 000000000000 no

$\infty 100000000000000$

M $00000000000 \mathrm{Ln}$

w 00000000000000

\begin{tabular}{l}
\hline \\
2 \\
2 \\
0 \\
0 \\
2 \\
0 \\
0 \\
0 \\
0 \\
0
\end{tabular}

nा $000000000 \mathrm{~m} 000$

$\rightarrow 00000000100000$

mI 00000000000000

NI 00000000000000

$-1000000100000000$

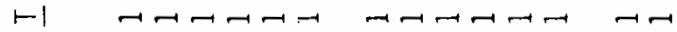

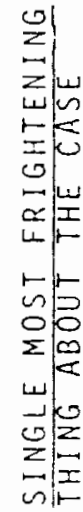

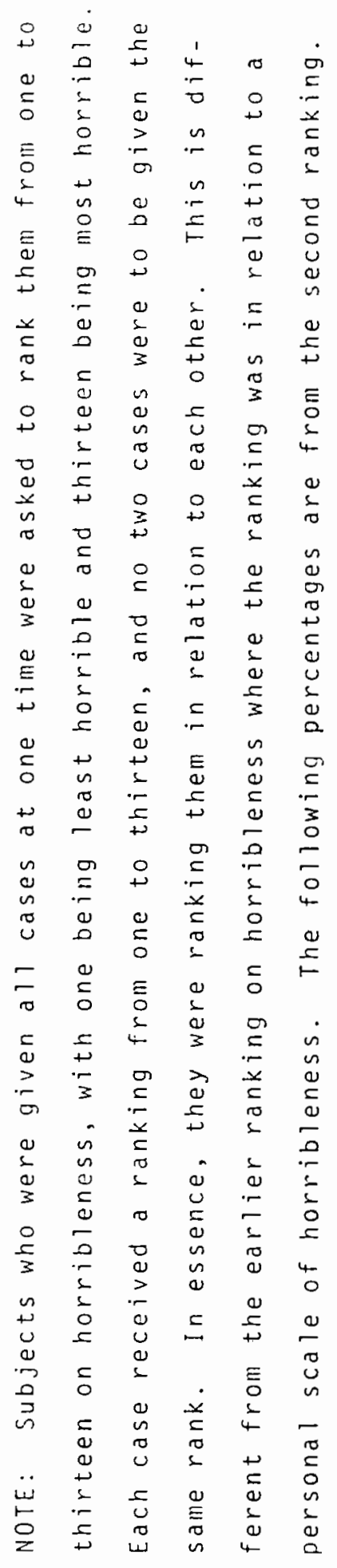




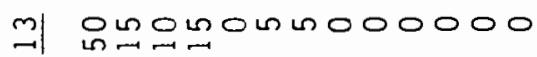

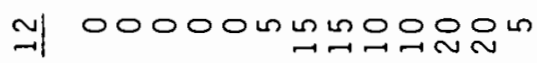

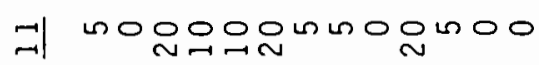

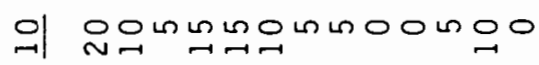

ol onnomornmogno

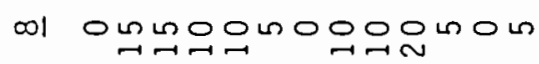

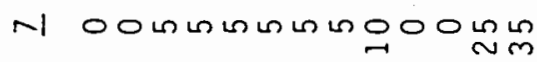

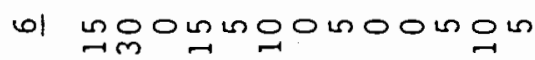

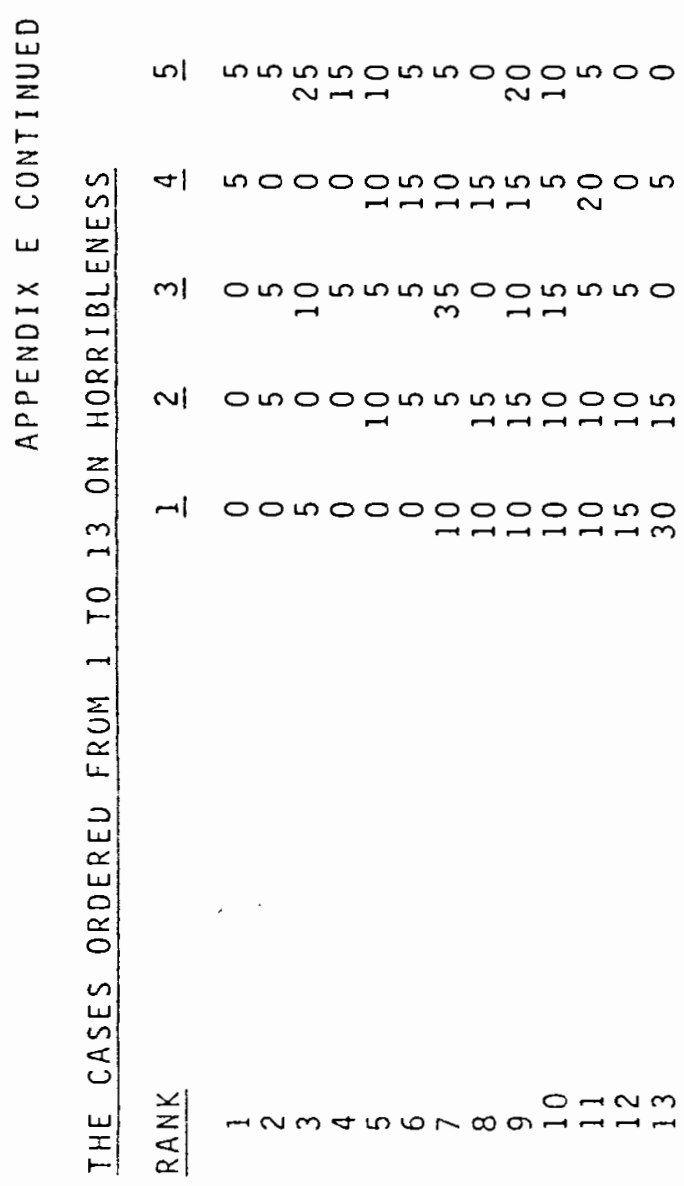




\section{SECTION I}

\section{LEGEND}

T) Total Percentage

F) Fema le Percentage

M) Male Percentage

1) Under 24 Years of Age

2) 24-29 Years of Age

3) 30 Years of Age and over

MANSON'S CHARACTER
Unbalanced/Crazy/Sick
Thought He Was/Thought
Of as a Diety
Persuasive/Charismatic
No Remorse/Guilt
Frightening/Spooky
Dangerous/Violent
Coldblooded/Ruthless
Bright/Intelligent
Evil
Famous/Well Known
Sadistic
Doesn't Know Right
From Wrong
Self Centered
Thought He Was/Thought
Ofas Devil/Anti-Christ
Doesn't Care About Others/
Incapable of Love
Antisocial
Wo Moral Code
Drifter
Musician/Poet
Deviant
No Value of Life
Boogie Man/Symbol
Deceitful

$\begin{array}{rrrrrr}I & \underline{F} & \underline{M} & \underline{1} & \underline{2} & \underline{3} \\ 43 & 45 & 41 & 45 & 47 & 37 \\ 22 & 20 & 26 & 21 & 21 & 26 \\ 21 & 18 & 26 & 10 & 32 & 26 \\ 10 & 15 & 4 & 0 & 16 & 21 \\ 7 & 8 & 7 & 10 & 11 & 0 \\ 7 & 13 & 0 & 7 & 11 & 0 \\ 6 & 5 & 7 & 10 & 5 & 0 \\ 6 & 8 & 4 & 3 & 0 & 16 \\ 4 & 8 & 0 & 3 & 5 & 5 \\ 3 & 3 & 4 & 7 & 0 & 0 \\ 3 & 3 & 4 & 3 & 0 & 5 \\ & & & & & \\ 3 & 3 & 5 & 3 & 0 & 5 \\ 3 & 5 & 0 & 3 & 5 & 0 \\ & & & & & \\ 3 & 5 & 0 & 3 & 5 & 0 \\ 3 & 5 & 0 & 3 & 5 & 0 \\ 1 & 0 & 4 & 3 & 0 & 0 \\ 1 & 0 & 4 & 3 & 0 & 0 \\ 1 & 0 & 4 & 3 & 0 & 0 \\ 1 & 3 & 0 & 0 & 0 & 5 \\ 1 & 0 & 4 & 3 & 0 & 0 \\ 1 & 0 & 4 & 3 & 0 & 0 \\ 1 & 0 & 4 & 3 & 0 & 0 \\ 1 & 3 & 0 & 0 & 5 & 0\end{array}$

\section{MANSON'S PHYSICAL ATTRIBUTES}

Long Hair
Eyes/Scary/Penetrating
Beard
Dirty/Unkempt
Changing Appearance
Smal]/Thin
Looks Like Christ
Part Black
Looks Like Devil
Deep/Gruff Voice
Scary Looking
Crazy Looking
Good Looking
Physicaliy Healthy
Unattractive

$\begin{array}{rrrrrr}13 & 18 & 7 & 0 & 11 & 37 \\ 12 & 15 & 7 & 7 & 16 & 16 \\ 10 & 15 & 4 & 7 & 11 & 16 \\ 7 & 13 & 0 & 7 & 0 & 16 \\ 4 & 0 & 11 & 3 & 11 & 0 \\ 3 & 3 & 4 & 3 & 0 & 5 \\ 3 & 5 & 0 & 3 & 0 & 5 \\ 3 & 5 & 0 & 0 & 5 & 5 \\ 1 & 3 & 0 & 3 & 0 & 0 \\ 1 & 3 & 0 & 0 & 0 & 5 \\ 1 & 0 & 4 & 0 & 5 & 0 \\ 1 & 3 & 0 & 0 & 5 & 0 \\ 1 & 3 & 0 & 0 & 0 & 5 \\ 1 & 3 & 0 & 0 & 0 & 5 \\ 1 & 3 & 0 & 0 & 0 & 5\end{array}$


APPENDIX F CONTINUED

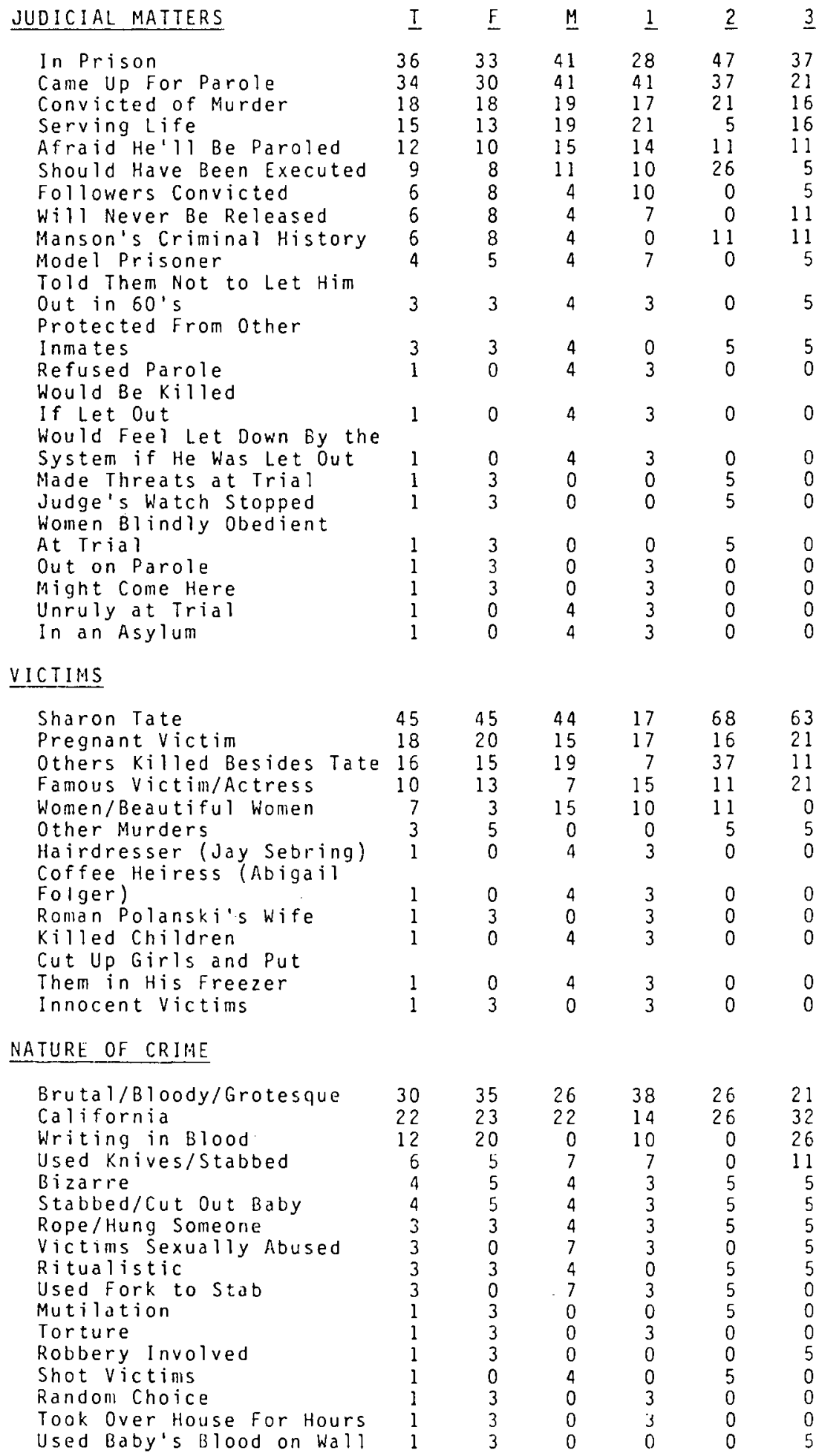


APPENDIX F CONTINUED

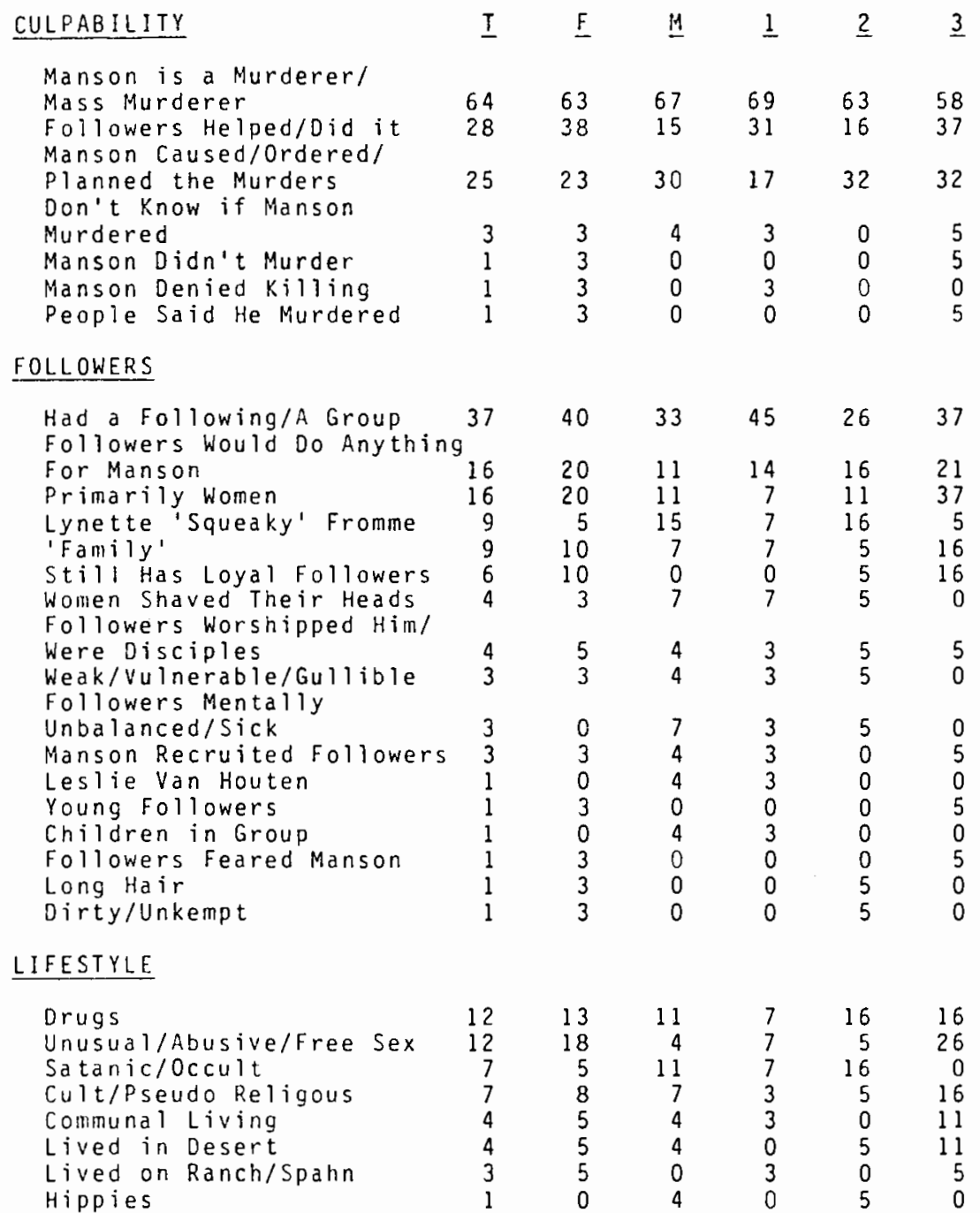

MANSON'S RELATIONSHIP TO FOLLOWERS

\begin{tabular}{|c|c|c|c|c|c|c|}
\hline Cult Leader & 24 & 20 & 30 & 14 & 21 & 37 \\
\hline Brainwashed/Controlled & 18 & 20 & 15 & 21 & 11 & 21 \\
\hline Leader & 13 & 13 & 15 & 10 & 16 & 16 \\
\hline Hypnotic Control & 12 & 13 & 11 & 3 & 16 & 1 \\
\hline Abnormal Hold & 10 & 13 & 7 & 3 & 11 & 21 \\
\hline Used Drugs to Control & 4 & 5 & 4 & 0 & 11 & \\
\hline Used People For Own Gain & 3 & 5 & 0 & 0 & 5 & \\
\hline $\begin{array}{l}\text { Had Others Do Dirty Work } \\
\text { Gave Them Something to }\end{array}$ & 3 & 0 & 7 & 0 & 11 & \\
\hline Believe in & 1 & 0 & 4 & 3 & 0 & 0 \\
\hline Guru & 1 & 0 & 4 & 0 & 0 & \\
\hline Hurt His Followers & 1 & 3 & 0 & 3 & 0 & \\
\hline SONS/INFLUENCES & & & & & & \\
\hline $\begin{array}{l}\text { Start a Race War } \\
\text { Anti-Establishment/ }\end{array}$ & 12 & 8 & 19 & 7 & 16 & \\
\hline $\begin{array}{l}\text { Anti-Society } \\
\text { Beatles Songs }\end{array}$ & 10 & 15 & 4 & 3 & 5 & 26 \\
\hline
\end{tabular}


APPENDIX F CONTINUED

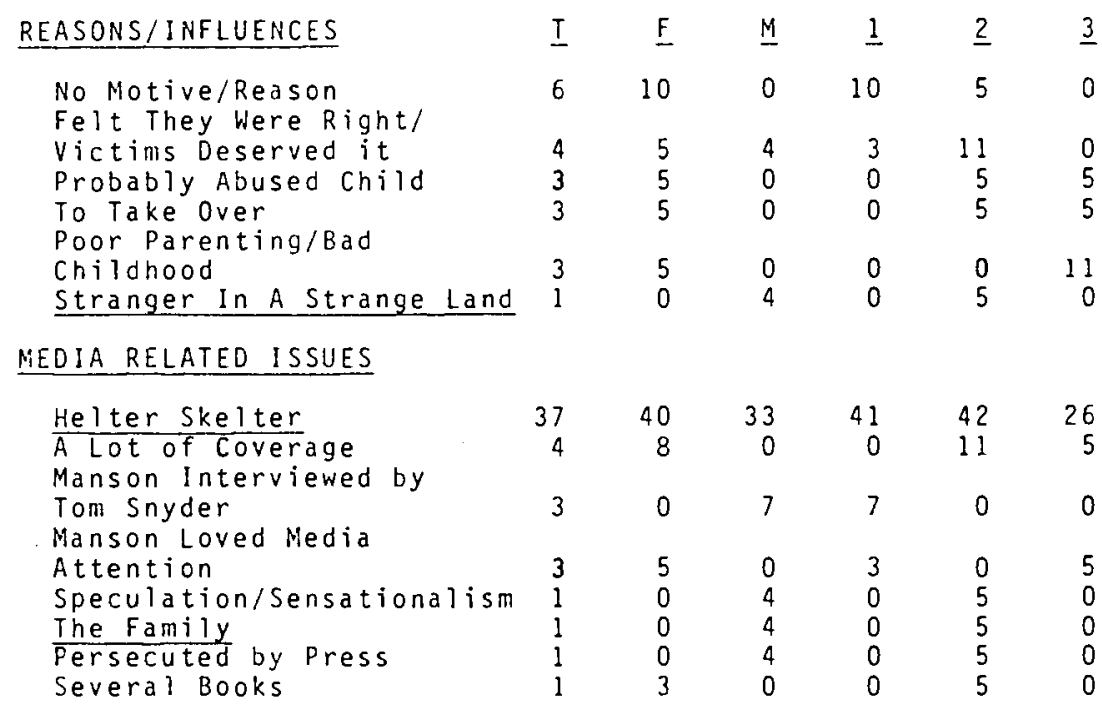

\section{MISCELLANEOUS}

Evokes Rage/Hate

Born Again Christians

Perpetuates Hate in Guise

of Love

Owns Land in California

Reminds Me of Hitler

Poor White Mother

Creepy Crawly Missions

Not a Deprived Background

Was in His $20^{\prime} \mathrm{s}$

Truman Capote Wrote

Helter Skelter

$\begin{array}{rrrrrr}4 & 8 & 0 & 3 & 5 & 5 \\ 3 & 5 & 0 & 0 & 0 & 11 \\ 1 & 3 & 0 & 0 & 0 & 5 \\ 1 & 0 & 4 & 0 & 5 & 0 \\ 1 & 3 & 0 & 0 & 5 & 0 \\ 1 & 3 & 0 & 0 & 0 & 5 \\ 1 & 0 & 4 & 0 & 5 & 0 \\ 1 & 3 & 0 & 0 & 0 & 5 \\ 1 & 3 & 0 & 0 & 0 & 5 \\ 1 & 3 & 0 & 0 & 0 & 5\end{array}$

\section{SECTION 11}

WHERE DID YOU HEAR ABOUT MANSON?

$\begin{array}{lrrrrrr}\text { Newspapers } & 61 & 68 & 52 & 34 & 74 & 89 \\ \text { Radio } & 31 & 38 & 22 & 7 & 47 & 53 \\ \text { TV } & 88 & 85 & 93 & 83 & 95 & 89 \\ \text { Magazines } & 23 & 35 & 30 & 14 & 53 & 42 \\ \text { Word of Mouth } & 73 & 73 & 74 & 79 & 89 & 47 \\ \text { Books } & 57 & 60 & 52 & 52 & 74 & 47 \\ \text { C.lasses } & 3 & 3 & 4 & 3 & 0 & 5 \\ \text { Movies } & 3 & 3 & 4 & 3 & 0 & 5\end{array}$

WHY DID IT HAPPEN?

Manson Was Crazy

$42 \cdot 58$

He Controlled Followers

Weak/Vulnerable Followers

Manson Was Charismatic

A Mission/Righting Wrongs

Drugs

Sign of the Tines

Sadistic/Enjoyed it

Some People Need Someone To Follow

Followers Blindly obeyed

Unacceptabie Ideas

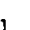


APPENDIX F CONTINUED

WHY DID IT HAPPEN?
I Don't Know
Cult
Convinced Followers He
Was a Diety
Satanic Connections
Used Followers to Act Out
His Own Hostilities
Acceptance/Peer Pressure
Control/Power
They Were All Deviant
No Sense of Right and
Wrong
Manson Wanted Attention
Don't Think He Knew Why
No Motive
Racism
Not a Sign of the Times
Followers Felt Obligated
Society That Breeds it
Used Sex To Control
Felt They Had the Right
No Value of Life

$\begin{array}{rrrrrr}I & \underline{F} & \underline{M} & \underline{1} & \underline{2} & \underline{3} \\ 6 & 5 & 7 & 10 & 0 & 5 \\ 6 & 5 & 7 & 7 & 5 & 5 \\ 6 & 10 & 0 & 10 & 0 & 5 \\ 4 & 0 & 11 & 3 & 11 & 0 \\ 4 & 8 & 0 & 3 & 0 & 11 \\ 4 & 3 & 7 & 3 & 5 & 5 \\ 3 & 5 & 0 & 3 & 5 & 0 \\ 3 & 3 & 4 & 3 & 5 & 0 \\ 1 & 3 & 0 & 3 & 0 & 0 \\ 1 & 0 & 4 & 3 & 0 & 0 \\ 1 & 0 & 4 & 3 & 0 & 0 \\ 1 & 3 & 0 & 0 & 5 & 0 \\ 1 & 3 & 0 & 0 & 5 & 0 \\ 1 & 0 & 4 & 3 & 0 & 0 \\ 1 & 3 & 0 & 3 & 0 & 0 \\ 1 & 0 & 4 & 0 & 5 & 0 \\ 1 & 0 & 4 & 0 & 5 & 0 \\ 1 & 3 & 0 & 3 & 0 & 0 \\ 1 & 3 & 0 & 0 & 5 & 0\end{array}$

DO YOU KNOW HIS ASSOCIATES?

No
Yes

WHO ARE THEY?

Ronald Hughes
Bugliosi
Shorty Shea
Lestie Van Houten
Lynette 'Squeaky' Fromme
Patti Hearst
Sharon Tate
Abigail Folger
Lesige Krenshaw

$\begin{array}{rrrrrr}1 & 3 & 0 & 0 & 0 & 5 \\ 1 & 3 & 0 & 0 & 0 & 5 \\ 1 & 3 & 0 & 0 & 0 & 5 \\ 1 & 0 & 4 & 3 & 0 & 0 \\ 3 & 3 & 4 & 0 & 11 & 0 \\ 1 & 3 & 0 & 3 & 0 & 0 \\ 1 & 3 & 0 & 0 & 5 & 0 \\ 1 & 3 & 0 & 0 & 5 & 0 \\ 1 & 3 & 0 & 0 & 5 & 0\end{array}$

\section{SHOULD MANSON BE PAROLED?}

Never
Strongly Oppose
Mildly Oppose

Mildly Oppos

Ind ifferent
WHY?

11


APPENDIX F LONTINUED

$\begin{array}{lllllll}\text { WHY? } & \text { T } & \text { F } & \underline{11} & \underline{1} & \underline{3} & \underline{3} \\ \text { We Don't Understand } & & & & & & \\ \text { Murderers Like That } & 1 & 3 & 0 & 0 & 5 & 0 \\ \text { No One Has the Right } & 1 & 3 & 0 & 1 & 0 & 0 \\ \text { Deserves Cruel and } & & & & & & \\ \text { Unusual Punishment } & 1 & 0 & 4 & 0 & 0 & 5 \\ \text { Might Come Here } & 1 & 3 & 0 & 3 & 0 & 0 \\ \text { Comitted a Crime } & 1 & 3 & 0 & 3 & 0 & 0 \\ \text { Can't Tell Right From Wrong } 1 & 3 & 0 & 0 & 5 & \end{array}$

SHOULD HIS ASSOCIATES BE PAROLED?

$\begin{array}{lrrrrrr}\text { Never } & 28 & 28 & 30 & 34 & 37 & 11 \\ \text { Strongly 0ppose } & 25 & 23 & 22 & 17 & 19 & 19 \\ \text { Mildy Oppose } & 21 & 25 & 15 & 33 & 11 & 11 \\ \text { Indifferent } & 3 & 3 & 4 & 4 & 0 & 5 \\ \text { Mildly Favor } & 6 & 5 & 7 & 0 & 7 & 11 \\ \text { Strongly Favor } & 1 & 3 & 0 & 0 & 0 & 5 \\ \text { No Answer } & 15 & 10 & 22 & 14 & 11 & 21\end{array}$

WHY?

$\begin{array}{lrrrrrr}\text { Dangerous/Might Repeat } & 15 & 8 & 26 & 17 & 21 & 5 \\ \begin{array}{l}\text { Responsible For Their } \\ \text { Actions }\end{array} & 13 & 15 & 11 & 10 & 26 & 5 \\ \begin{array}{l}\text { They Murdered } \\ \text { Arent Responsibiel }\end{array} & 10 & 18 & 0 & 10 & 26 & 5 \\ \begin{array}{l}\text { Branwashed } \\ \text { May Still Be Under }\end{array} & 9 & 13 & 4 & 10 & 11 & 5 \\ \text { Manson's Control } & 7 & 10 & 4 & 3 & 16 & 5 \\ \text { They are Crazy } & 7 & 8 & 7 & 7 & 7 & 5 \\ \text { If Reformed } & 7 & 13 & 0 & 3 & 5 & 16 \\ \text { Might Be Controlled Again } & 7 & 8 & 7 & 0 & 21 & 5 \\ \text { Can't Be Reformed } & 6 & 5 & 7 & 3 & 11 & 5 \\ \text { Look at Separately } & 6 & 5 & 7 & 7 & 11 & 0 \\ \text { Should Pay } & 6 & 5 & 7 & 7 & 5 & 5 \\ \text { Fromme Attempted to } & & & & & & 5 \\ \text { Assasinate Ford } & 4 & 3 & 7 & 7 & 0 & 5 \\ \text { Could Be Reformed } & 4 & 8 & 0 & 7 & 0 & 5 \\ \text { I Dont Know } & 4 & 3 & 7 & 7 & 0 & 0 \\ \text { Should Be Executed } & 3 & 0 & 7 & 3 & 5 & 0 \\ \text { Think Like Manson } & 3 & 3 & 4 & 7 & 0 & 0 \\ \text { Weak People/Blindly Follow } & 3 & 3 & 4 & 7 & 0 & 5 \\ \text { OK Without His Influence } & 3 & 8 & 0 & 3 & 0 & 0 \\ \text { No One Has the Right } & 1 & 3 & 0 & 3 & 0 & 0 \\ \text { After Therapy } & 1 & 3 & 0 & 3 & 0 & 0 \\ \text { Don't Know Right From Wrong } & 1 & 3 & 0 & 0 & 0 & 5 \\ \text { Need Therapy } & 1 & 0 & 4 & 3 & 0 & 0 \\ \text { Nature of Crime } & 1 & 0 & 4 & 3 & 0 & 0 \\ \text { They Killed For Manson } & 1 & 3 & 0 & 3 & 0 & 0\end{array}$

WHAT SHOULD HAVE HAPPENED TO MANSON?

$\begin{array}{lrrrrrr}\text { Death Sentence } & 64 & 65 & 63 & 72 & 58 & 58 \\ \text { Life Sentence } & 22 & 23 & 22 & 17 & 32 & 21 \\ \text { Prison } & 10 & 8 & 15 & 10 & 5 & 16 \\ \text { Therapy } & 10 & 10 & 11 & 7 & 11 & 16 \\ \text { Institutionalized } & 6 & 5 & 7 & 3 & 5 & 11 \\ \text { Try To Reform } & 4 & 3 & 7 & 0 & 5 & 11 \\ \text { Study Him } & 3 & 3 & 4 & 3 & 0 & 5 \\ \text { Cruel \& Unusual Punishment } & 3 & 5 & 0 & 0 & 5 & 5 \\ \text { Same Treatment as Victims } & 1 & 0 & 4 & 3 & 0 & 0 \\ \text { I Don't Know } & 1 & 0 & 4 & 0 & 5 & 0\end{array}$

WHAT SHOULD HAVE HAPPENED TO HIS ASSOCIATES?

Death Sentence

$39 \quad 30 \quad 52$

48 
APPENDIX F CONTINUED

WHAT SHOULO HAVE HAPPENED

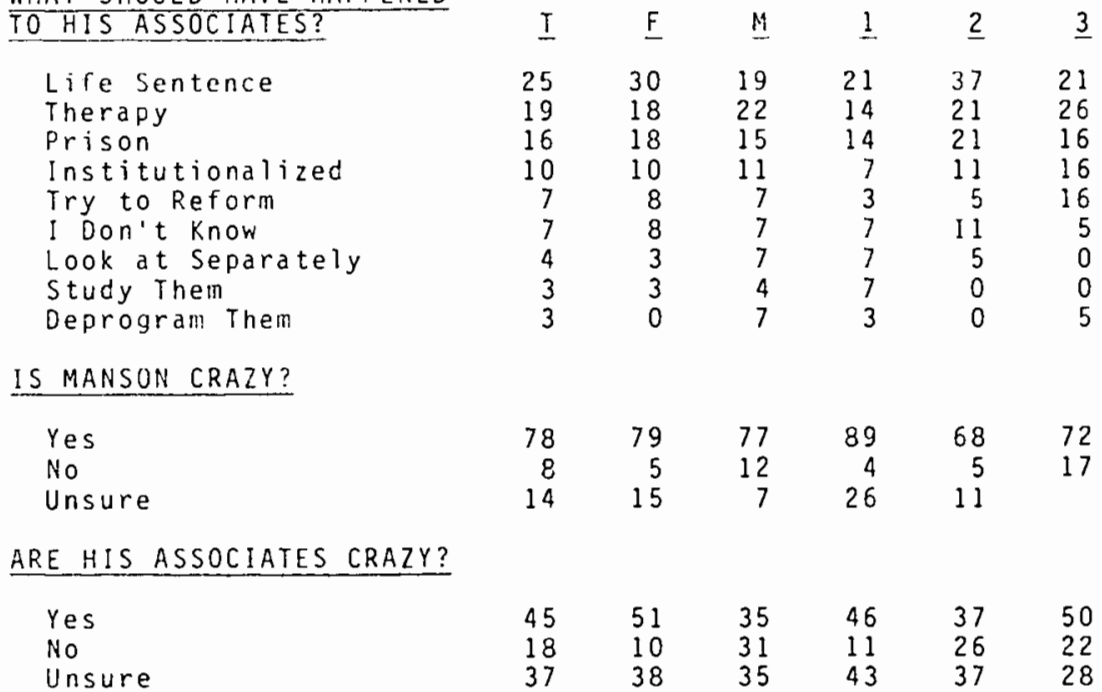

HUW DUES THIS AFFECT YOUR FEELINGS OF SAFETY?

$\begin{array}{lrrrrrr}\text { Unsafe } & 10 & 13 & 7 & 0 & 26 & 11 \\ \text { Much Less Safe } & 15 & 20 & 7 & 10 & 16 & 21 \\ \text { A Little Less Safe } & 42 & 48 & 33 & 52 & 26 & 42 \\ \text { No Affect } & 30 & 18 & 48 & 31 & 32 & 26 \\ \text { A Little More Safe } & 1 & 3 & 0 & 3 & 0 & 0 \\ \text { No Answer } & 1 & 0 & 4 & 3 & 0 & 0\end{array}$

WHY?

\begin{tabular}{|c|c|c|c|c|c|c|}
\hline \multirow{4}{*}{$\begin{array}{l}\text { A Lot of Crazy People } \\
\text { Reminds Me it Happens } \\
\text { I Could Be a Victim } \\
\text { It Happens/Why Worry }\end{array}$} & 15 & 20 & 7 & 14 & 16 & 16 \\
\hline & 12 & 20 & 0 & 10 & 11 & 16 \\
\hline & 9 & 0 & 22 & 7 & 16 & 5 \\
\hline & 9 & 5 & 15 & 7 & 16 & 5 \\
\hline Controllers Like Manson & 9 & 13 & 4 & 7 & 5 & 16 \\
\hline Has Nothing to Do with Me & 7 & 8 & 7 & 7 & 5 & 11 \\
\hline Randominess & 7 & 13 & 0 & 7 & 11 & r \\
\hline Life Isn't Safe & 6 & 8 & 4 & 3 & 11 & 5 \\
\hline It Could Happen Again & 6 & 8 & 4 & 10 & 5 & 0 \\
\hline Can Control/Avoid it & 4 & 0 & 11 & 10 & 0 & 0 \\
\hline No Defense & 4 & 3 & 7 & 7 & 5 & 0 \\
\hline Weak/Controllable People & 4 & 8 & 0 & 7 & 5 & 0 \\
\hline Who Can You Trust & 3 & 3 & 4 & 3 & 5 & 0 \\
\hline Not Common & 3 & 3 & 4 & 3 & 0 & 5 \\
\hline Society That Breeds it & 3 & 3 & 4 & 3 & 0 & 5 \\
\hline It Happens All the Times & 3 & 3 & 4 & 0 & 5 & 5 \\
\hline No Value of Life & 3 & 5 & 0 & 0 & 0 & 11 \\
\hline Lived in California Then & 3 & 5 & 0 & 0 & 0 & 11 \\
\hline No Hotive & 1 & 3 & 0 & 0 & 5 & 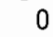 \\
\hline Cults & 1 & 3 & 0 & 0 & 0 & 5 \\
\hline Mass Murder is Terrifying & 1 & 3 & 9 & 9 & 9 & 5 \\
\hline Might Have Set an Example & 1 & 0 & 4 & 3 & 0 & 0 \\
\hline Might Let Him Out & 1 & 3 & 0 & 0 & 5 & 0 \\
\hline Faith in God & 1 & 0 & 4 & 0 & 5 & 0 \\
\hline I Don't Think About it & 1 & 3 & 0 & 3 & 0 & 0 \\
\hline Media Influence & 1 & 0 & 4 & 3 & 0 & \\
\hline Anything is Possible & 1 & 0 & 4 & 3 & 0 & 0 \\
\hline Fate & 1 & 3 & 0 & 3 & 0 & U \\
\hline Feel Safer With Manson & & & & & & \\
\hline In Prison & 1 & 3 & 0 & 3 & 0 & 0 \\
\hline Killing For a Cause & i & 3 & 0 & 0 & 0 & \\
\hline No Remorse & 1 & 3 & 0 & 0 & 0 & 5 \\
\hline
\end{tabular}


APPENDIX F CONTINUED

WHAT IS THE PROBABILITY OF THIS HAPPENING AGAIN?

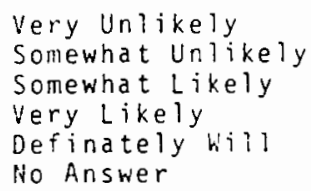

$\begin{array}{rrrrrr}\text { I } & \underline{F} & \underline{M} & \underline{1} & \underline{2} & \underline{3} \\ 4 & 3 & 7 & 3 & 0 & 11 \\ 7 & 8 & 7 & 17 & 0 & 0 \\ 36 & 43 & 26 & 52 & 16 & 32 \\ 36 & 33 & 41 & 17 & 58 & 42 \\ 15 & 13 & 19 & 10 & 21 & 16 \\ 1 & 3 & 0 & 0 & 5 & 0\end{array}$

WHY?

Similar Crimes Happen 28

Lots of Crazy People 25

Society That Breeds it 18

cults

Manson Types

Anything is Possible

Weak Followers

If Someone Else Could

Get Followers

Might Have Set an Example

Not Common

Manson Would Repeat

Life Isn't Safe

Not Enough Heip for

Such Peopie

Drugs

Know More About Cults Now

Randomness

Why Not

Manson Would Be Closely

Watched

Media Sets an Example

Increased Mass Murder

Someone Might For Attention 1

IS THIS MUROER:

Senseless

Understandable

No Answer

90

?

$\begin{array}{rrrrr}33 & 22 & 14 & 53 & 26 \\ 30 & 19 & 24 & 21 & 32 \\ 20 & 15 & 10 & 5 & 42 \\ 20 & 11 & 14 & 26 & 11 \\ 15 & 4 & 7 & 5 & 21 \\ 5 & 11 & 14 & 5 & 0 \\ 8 & 7 & 7 & 11 & 5\end{array}$

$\begin{array}{llllll}6 & 5 & 7 & 10 & 0 & 5\end{array}$

$\begin{array}{llllll}6 & 5 & 7 & 3 & 11 & 5\end{array}$

$\begin{array}{lllll}3 & 3 & 4 & 7 & 0\end{array}$

$\begin{array}{lllll}1 & 0 & 4 & 0 & 5\end{array}$

10

$\begin{array}{ll}1 & 0 \\ 1 & 0\end{array}$

$\begin{array}{llll}4 & 0 & 0 & 5\end{array}$

$\begin{array}{lllll}1 & 3 & 0 & 3 & 0\end{array}$

HY?

No Motive/Reason
Murder is Senseless
Wasn't Self Defense
Nature of Crime
Understandable to Murderer
Wasn't For Revenge
Randomness
Sadistic/Enjoyed it
I Don't Know
Can Understand Anything
Hanson is Possessed
Killing For a Cause
Coldbiooded
Murderer is Crazy
Followers Were Brainwashed
No Remorse/Guilt
I Could Be a Victim
Number of Victims

$\begin{array}{rrrrrr}39 & 43 & 33 & 28 & 47 & 47 \\ 24 & 28 & 19 & 31 & 26 & 11 \\ 10 & 15 & 4 & 14 & 26 & 11 \\ 9 & 10 & 7 & 7 & 16 & 5 \\ 7 & 3 & 15 & 7 & 16 & 0 \\ 6 & 10 & 0 & 10 & 0 & 5 \\ 4 & 3 & 7 & 7 & 0 & 5 \\ 4 & 3 & 7 & 3 & 5 & 0 \\ 3 & 5 & 0 & 0 & 0 & 11 \\ 3 & 5 & 0 & 0 & 0 & 11 \\ 3 & 0 & 7 & 3 & 5 & 0 \\ 3 & 0 & 7 & 3 & 5 & 0 \\ 3 & 5 & 0 & 3 & 0 & 5 \\ 1 & 0 & 4 & 0 & 5 & 0 \\ 1 & 3 & 0 & 3 & 0 & 0 \\ 1 & 3 & 0 & 0 & 5 & 0 \\ 1 & 0 & 4 & 0 & 5 & 0 \\ 1 & 3 & 0 & 0 & 5 & 0\end{array}$


APPENDIX F CONTINUED

\begin{tabular}{lrrrrrr} 
HORRIBLENESS: SCALE 1-10. & & & & & \\
\hline 10 IS MOST HORRIBLE. & $I$ & - & $\underline{1}$ & 1 & $\underline{2}$ & $\underline{3}$ \\
\hline 10 & 69 & 68 & 70 & 66 & 84 & 58 \\
9 & 12 & 13 & 11 & 10 & 0 & 26 \\
8 & 10 & 13 & 7 & 14 & 5 & 11 \\
7 & 6 & 3 & 11 & 7 & 11 & 0 \\
No Answer & 3 & 5 & 0 & 3 & 0 & 5
\end{tabular}

BIZARRENESS: SCALE 1-10.10 IS MOST BIZARRE.

$\begin{array}{lrrrrrr}10 & 49 & 58 & 37 & 45 & 63 & 42 \\ 9 & 12 & 15 & 7 & 10 & 5 & 21 \\ 8 & 16 & 13 & 22 & 17 & 16 & 16 \\ 7 & 9 & 3 & 19 & 14 & 11 & 0 \\ 6 & 4 & 3 & 7 & 7 & 0 & 5 \\ 110 \text { Answer } & 9 & 10 & 4 & 7 & 5 & 16\end{array}$

WHAT IS THE SINGLE MOST FRIGHTENING THING ABOUT THIS CASE?

\begin{tabular}{|c|c|c|c|c|c|c|}
\hline $\begin{array}{l}\text { Someone Can Control } \\
\text { Get Others to Kill }\end{array}$ & 18 & 15 & 22 & 14 & 26 & 1 \\
\hline Randomness & 16 & 23 & 7 & 17 & 16 & 10 \\
\hline $\begin{array}{l}\text { I could Be a Victin } \\
\text { That People Are That }\end{array}$ & 13 & 15 & 11 & 21 & 11 & \\
\hline Crazy/Can Do it & 10 & 15 & 4 & 10 & 5 & \\
\hline Pregnant Victim & 9 & 13 & 4 & 7 & 21 & \\
\hline No Motive & 7 & 8 & 7 & 7 & 11 & \\
\hline Weak/Vulnerable People & 7 & 10 & 4 & 3 & 5 & \\
\hline Society That Breeds it & 7 & 5 & 11 & 0 & 16 & \\
\hline No value of Life & 7 & 10 & 4 & 14 & 5 & \\
\hline Could/Will Happen Again & 7 & 5 & 11 & 10 & 11 & \\
\hline Nature of Crime & 7 & 8 & 7 & 10 & 11 & \\
\hline No Remorse/Guilt & 6 & 5 & 7 & 3 & 11 & \\
\hline $\begin{array}{l}\text { Laws Aren't Tough Enough } \\
\text { Manson/Followers Could }\end{array}$ & 6 & 8 & 4 & 3 & 5 & \\
\hline Be Paroled & 6 & 8 & 4 & 7 & 11 & \\
\hline That it Happened & 6 & 10 & 0 & 3 & 5 & \\
\hline No Defense/Protection & 4 & 8 & 0 & 7 & 0 & \\
\hline More Like Manson/Might Be & 4 & 3 & 7 & 5 & 11 & \\
\hline $\begin{array}{l}\text { Sadism/Enjoyed it } \\
\text { They Didn't Get Help/ }\end{array}$ & 4 & 3 & 4 & 7 & 0 & \\
\hline Problem Undetected & 3 & 3 & 4 & 3 & 0 & \\
\hline Who Can You Trust & 3 & 0 & 7 & 3 & 5 & \\
\hline Loss of Life & 3 & 3 & 4 & 3 & 0 & \\
\hline Lots of Crazy People & 1 & 0 & 4 & 3 & 0 & \\
\hline Hay Have Set an Example & 1 & 0 & 4 & 3 & 0 & \\
\hline Life Isn't Safe & 1 & 0 & 4 & 0 & 5 & \\
\hline Cutting Open & & & & & & \\
\hline Sharon's Stomach & 1 & 0 & 4 & 0 & 5 & \\
\hline $\begin{array}{l}\text { Could Happen Here } \\
\text { lf Victims Not Christians }\end{array}$ & 1 & 0 & 4 & 0 & 5 & \\
\hline They'll Go To Hell & 1 & 0 & 4 & 0 & 5 & \\
\hline Could Affect Someone I know & 1 & 3 & 0 & 3 & 0 & \\
\hline $0 c c u 1 t$ & 1 & 3 & 0 & 0 & 5 & \\
\hline Increased Mass Murder & 1 & 3 & 0 & 0 & 0 & \\
\hline Killing For a Cause & 1 & 3 & 0 & 0 & 0 & \\
\hline Someone Could Control Me & 1 & 3 & 0 & 0 & 0 & \\
\hline Drugs & 1 & 3 & 0 & 0 & 0 & \\
\hline Children Are Abused & 1 & 3 & 0 & 0 & 0 & \\
\hline
\end{tabular}




\section{SECTION I}

\section{LEGEND}
T) Total Percentage
F) Female Percentage
1) Under 24 Years of Age
M) Male Percentage
2) 24-29 Years of Age
3) 30 Years of Age or Over

\begin{tabular}{|c|c|c|c|c|c|c|}
\hline URDERER/CASE & $I$ & $\underline{F}$ & $\underline{M}$ & 1 & $\underline{2}$ & $\underline{3}$ \\
\hline Charles Manson & 51 & 48 & 52 & 53 & 68 & 37 \\
\hline Green River Killer & 46 & 37 & 50 & 38 & 68 & 43 \\
\hline Huberty/HcDonalds Shooting & 37 & 41 & 35 & 40 & 37 & 33 \\
\hline I-5 Xilier & 29 & 26 & 31 & 41 & 32 & 30 \\
\hline Jones town & 28 & 37 & 26 & 35 & 32 & 17 \\
\hline Atlanta Child Murders & 25 & 15 & 29 & 28 & 21 & 23 \\
\hline Nazi Germany & 25 & 15 & 29 & 28 & 21 & 23 \\
\hline Richard Speck & 18 & 15 & 19 & 3 & 16 & 40 \\
\hline Son of Sam & 18 & 15 & 19 & 3 & 16 & 40 \\
\hline Hillside Strangler & 15 & 19 & 13 & 13 & 26 & 10 \\
\hline John Wayne Gacy & 13 & 22 & 10 & 10 & 11 & 20 \\
\hline Ted Bundy & 12 & 15 & 11 & 13 & 16 & 10 \\
\hline Jack the Ripper & 11 & 11 & 11 & 10 & 16 & 10 \\
\hline Seattle Chinatown Massacre & 10 & 4 & 13 & 15 & 16 & 0 \\
\hline Lt. James Calley & 9 & 11 & 8 & 5 & 11 & 13 \\
\hline Shooting in Salem Bar & 8 & 15 & 5 & 13 & 11 & 0 \\
\hline Juan Corona & 7 & 4 & 8 & 0 & 11 & 13 \\
\hline Charles whitman & 7 & 11 & 5 & 3 & 0 & 17 \\
\hline Dr. McDonald/Fatal Vision & 6 & 7 & 5 & 8 & 11 & 0 \\
\hline Vietnam & 4 & 15 & 0 & 0 & 5 & 10 \\
\hline $\begin{array}{l}\text { Marines Killed By Truck } \\
\text { Bomb in Beirut }\end{array}$ & 4 & 7 & 3 & 5 & 5 & 3 \\
\hline Marquette & 4 & 7 & 3 & 5 & 5 & 3 \\
\hline All Wars & 4 & 4 & 5 & 3 & 5 & 7 \\
\hline Clutter/In Cold Brood & 4 & 4 & 5 & 0 & 0 & 13 \\
\hline Munich Olympics & 3 & 4 & 3 & 8 & 0 & 0 \\
\hline Texas Chainsaw (Movie) & 3 & 11 & 0 & 8 & 0 & 0 \\
\hline Australian Sportscar Driver & 3 & 0 & 5 & 5 & 0 & 3 \\
\hline Elizabeth Diane Downes & 3 & 0 & 5 & 5 & 5 & 0 \\
\hline Henry Lee Lucas & 3 & 7 & 2 & 3 & 5 & 3 \\
\hline Dean Corll & 2 & 4 & 2 & 3 & 0 & 3 \\
\hline Lynching of Blacks & 2 & 4 & 2 & 0 & 5 & 3 \\
\hline
\end{tabular}


APPENDIX G CONTINUED

\begin{tabular}{|c|c|c|c|c|c|}
\hline MURDERER/CASE & $I$ & $\underline{F}$ & $\underline{M}$ & $\underline{1}$ & $\underline{2}$ \\
\hline Indian Massacres & 2 & 7 & 0 & 0 & 5 \\
\hline World War II & 2 & 4 & 2 & 3 & 0 \\
\hline Valentines Day Massacre & 2 & 4 & 2 & 3 & 0 \\
\hline War in Middle East & 2 & 7 & 0 & 7 & 0 \\
\hline Brudos & 2 & 0 & 3 & 3 & 0 \\
\hline Yorkshire Ripper & 2 & 4 & 2 & 3 & 5 \\
\hline Zodiac Killer & 2 & 0 & 3 & 0 & 5 \\
\hline $\begin{array}{l}\text { LA Summer Olympics/Man } \\
\text { Who Drove on Sidewalk }\end{array}$ & 2 & 0 & 3 & 0 & 5 \\
\hline Terrorism & 2 & 4 & 2 & 0 & 0 \\
\hline Goetz/NY Subway & 2 & 4 & 2 & 5 & 0 \\
\hline Christians in Rome/Lions & 2 & 7 & 0 & 3 & 0 \\
\hline Lizzie Borden & 1 & 4 & 0 & 3 & 0 \\
\hline US Hostages & 1 & 4 & 0 & 3 & 0 \\
\hline Soviet Purses & 1 & 4 & 0 & 0 & 5 \\
\hline Detroit Riots & 1 & 4 & 0 & 0 & 5 \\
\hline Killing of SLA & 1 & 4 & 0 & 0 & 0 \\
\hline Charles Starkweather & 1 & 4 & 0 & 0 & 0 \\
\hline Kent State & 1 & 4 & 0 & 0 & 0 \\
\hline Reagan/Cultural Genocide & 1 & 4 & 0 & 0 & 0 \\
\hline Boston Massacre & 1 & 0 & 2 & 3 & 0 \\
\hline Shooting at Autzen Stadium & 1 & 0 & 2 & 0 & 5 \\
\hline Richard Chase & 1 & 0 & 2 & 0 & 5 \\
\hline Shan of Iran & 1 & 0 & 2 & 0 & 5 \\
\hline Idi Amin & 1 & 0 & 2 & 0 & 5 \\
\hline Dan White & 1 & 0 & 2 & 0 & 5 \\
\hline Jesse James & 1 & 0 & 2 & 0 & 5 \\
\hline Bonnie \& Clyde & 1 & 0 & 2 & 0 & 5 \\
\hline Abortion Clinics & 1 & 0 & 2 & 0 & 5 \\
\hline Tylenol Case & 1 & 0 & 2 & 0 & 5 \\
\hline Jeanace Freeman & 1 & 0 & 2 & 0 & 0 \\
\hline Zebra & 1 & 0 & 2 & 0 & 0 \\
\hline $\begin{array}{l}\text { Killing of Babies at } \\
\text { Time of Christ }\end{array}$ & 1 & 0 & 2 & 0 & 0 \\
\hline Bluebeard & 1 & 0 & 2 & 0 & 0 \\
\hline Hiroshima & 1 & 0 & 2 & 3 & 0 \\
\hline Michigan Murders/Collins & 1 & 0 & 2 & 0 & 0 \\
\hline Altamont & 1 & 4 & 0 & 3 & 0 \\
\hline Egyptian Human Sacrifice & 1 & 4 & 0 & 3 & 0 \\
\hline Christ and Disciples & 1 & 4 & 0 & 3 & 0 \\
\hline $\begin{array}{l}\text { Woman Driving on Sidewalk } \\
\text { In New York }\end{array}$ & 1 & 4 & 0 & 3 & 0 \\
\hline Russian Revolution & 1 & 4 & 0 & 0 & 3 \\
\hline
\end{tabular}


APFENDIX G CONTINUED

SECTION II

\begin{tabular}{lrrrrrr} 
HOW MANY VICTIMS & & & & & \\
\hline BEFORE IT IS MASS MURDER? & $I$ & $\underline{-}$ & $\underline{M}$ & 1 & $\underline{2}$ & $\underline{3}$ \\
\hline & 28 & 26 & 29 & 20 & 42 & 30 \\
3 & 38 & 48 & 34 & 40 & 26 & 43 \\
4 & 8 & 4 & 10 & 8 & 11 & 7 \\
5 & 13 & 15 & 13 & 20 & 11 & 7 \\
6 & 1 & 0 & 2 & 3 & 11 & 0 \\
10 & 6 & 4 & 6 & 8 & 0 & 7
\end{tabular}

HOW HANY TIMES BEFORE IT IS MASS MURDER?

$\begin{array}{lrrrrrr}1 & 6 & 7 & 5 & 5 & 5 & 7 \\ 2 & 37 & 41 & 35 & 38 & 42 & 33 \\ 3 & 31 & 33 & 31 & 25 & 26 & 43 \\ 4 & 10 & 11 & 10 & 10 & 11 & 10 \\ 5 & 6 & 0 & 8 & 10 & 5 & 0 \\ 6 & 1 & 0 & 2 & 3 & 0 & 0 \\ 9 & 1 & 0 & 2 & 3 & 0 & 0 \\ 10 & 1 & 0 & 2 & 3 & 0 & 0\end{array}$

IS IT MASS MURDER IF THE MURDERER IS RELATED TO THE VICTIMS?

$\begin{array}{lrrrrrr}\text { Yes } & 90 & 78 & 95 & 93 & 89 & 87 \\ \text { No } & 4 & 11 & 2 & 3 & 0 & 10 \\ \text { No Answer } & 2 & 4 & 2 & 3 & 5 & 0 \\ \text { Sometimes } & 3 & 7 & 2 & 3 & 5 & 3\end{array}$

HOW DOES THIS AFFECT YOUR FEELINGS OF SAFETY?

$\begin{array}{lrrrrrr}\text { No Affect } & 16 & 37 & 6 & 15 & 21 & 13 \\ \text { A Little Less Safe } & 56 & 44 & 61 & 63 & 63 & 43 \\ \text { Much Less Safe } & 13 & 4 & 18 & 15 & 5 & 17 \\ \text { Unsafe } & 13 & 11 & 15 & 8 & 5 & 27 \\ \text { No Answer } & 1 & 4 & 0 & 0 & 5 & 0\end{array}$

ARE SUCH MURDERERS CRAZY?

$\begin{array}{lrrrrrr}\text { Yes } & 63 & 70 & 60 & 65 & 47 & 70 \\ \text { No } & 6 & 4 & 6 & 5 & 5 & 7 \\ \text { Unsure } & 28 & 19 & 32 & 30 & 37 & 20 \\ \text { No Answer } & 3 & 7 & 2 & 0 & 11 & 3\end{array}$

ARE SUCH MURDERS:

$\begin{array}{lrrrrrr}\text { Senseless } & 79 & 78 & 79 & 90 & 84 & 60 \\ \text { Understandable } & 11 & 15 & 10 & 5 & 0 & 27 \\ \text { No Answer } & 10 & 7 & 11 & 5 & 16 & 13\end{array}$

IS IT MASS MURDER IF SOMEONE REPEATEDLY KILLS IN THE COURSE OF ROBBERY?

$\begin{array}{lrrrrrr}\text { Yes } & 69 & 56 & 74 & 73 & 58 & 70 \\ \text { No } & 15 & 26 & 10 & 13 & 5 & 20 \\ \text { No Answer } & 1 & 4 & 0 & 0 & 5 & 0 \\ \text { Sometimes } & 17 & 15 & 18 & 15 & 32 & 10\end{array}$

HOW DOES THIS AFFECT YOUR FEELIMGS OF SAFETY?

$\begin{array}{lrrrrrr}\text { No Affect } & 15 & 37 & 5 & 13 & 21 & 13 \\ \text { A Little Less Safe } & 57 & 41 & 65 & 58 & 58 & 57 \\ \text { Much Less Safe } & 17 & 7 & 21 & 28 & 11 & 7 \\ \text { Unsafe } & 10 & 11 & 10 & 3 & 5 & 23 \\ \text { No Answer } & 1 & 4 & 0 & 0 & 5 & 0\end{array}$


APPENDIX G CONTINUED

$\begin{array}{lrrrrrr}\text { ARE SUCH MURDERERS CRAZY? } & \text { I } & \underline{F} & \underline{M} & \underline{1} & \underline{2} & \underline{3} \\ \text { Yes } & 54 & 52 & 55 & 57 & 42 & 57 \\ \text { No } & 16 & 15 & 16 & 8 & 11 & 30 \\ \text { Unsure } & 27 & 26 & 27 & 35 & 37 & 10 \\ \text { No Answer } & 3 & 7 & 2 & 0 & 11 & 3\end{array}$

ARE SUCH MURDERS:

$\begin{array}{lrrrrrr}\text { Senseless } & 82 & 78 & 84 & 93 & 74 & 73 \\ \text { Understandable } & 15 & 15 & 15 & 8 & 11 & 27 \\ \text { No Answer } & 3 & 7 & 2 & 0 & 16 & 0\end{array}$

IS IT MASS MURDER IF SOMEONE KILLS REPEATEDLY IN THE COURSE OF RAPE?

$\begin{array}{lrrrrrr}\text { Yes } & 88 & 74 & 94 & 88 & 74 & 97 \\ \text { No Answer } & 7 & 15 & 3 & 10 & 5 & 3 \\ \text { No Answes } & 1 & 4 & 0 & 0 & 5 & 0 \\ \text { Sometimies } & 4 & 7 & 3 & 3 & 16 & 0\end{array}$

HOW DOES THIS AFFECT YOUR FEELINGS OF SAFETY?

$\begin{array}{lrrrrrr}\text { No Affect } & 17 & 56 & 0 & 15 & 32 & 10 \\ \text { A Little Less Safe } & 33 & 22 & 37 & 35 & 16 & 40 \\ \text { Much Less Safe } & 24 & 4 & 32 & 28 & 32 & 13 \\ \text { Unsafe } & 26 & 15 & 31 & 23 & 16 & 37 \\ \text { No Answer } & 1 & 4 & 0 & 0 & 5 & 0\end{array}$

ARE SUCH MURDERERS CRAZY?

$\begin{array}{lrrrrrr}\text { Yes } & 75 & 74 & 76 & 75 & 58 & 87 \\ \text { No } & 0 & 4 & 6 & 3 & 5 & 10 \\ \text { Unsure } & 15 & 11 & 16 & 20 & 26 & 0 \\ \text { Ho Answer } & 4 & 11 & 2 & 3 & 11 & 3\end{array}$

ARE SUCH MURDERS:

$\begin{array}{lrrrrrr}\text { Senseless } & 82 & 85 & 81 & 93 & 84 & 67 \\ \text { Understandable } & 12 & 11 & 13 & 8 & 11 & 20 \\ \text { No Answer } & 6 & 4 & 6 & 0 & 5 & 13\end{array}$

IS IT MASS MURDER IF MILITARY PERSONNEL ARE KILLED AT WAR?

$\begin{array}{lrrrrrr}\text { Yes } & 58 & 30 & 71 & 55 & 58 & 63 \\ \text { No } & 24 & 48 & 13 & 28 & 21 & 20 \\ \text { No Answer } & 1 & 4 & 0 & 0 & 5 & 0 \\ \text { Sometimes } & 17 & 19 & 16 & 18 & 16 & 17\end{array}$

HOW DOES THIS AFFECT YOUR FEELINGS OF SAFETY?

$\begin{array}{lrrrrrr}\text { No Affect } & 33 & 56 & 23 & 40 & 26 & 27 \\ \text { A Littie Less Safe } & 42 & 15 & 53 & 43 & 47 & 37 \\ \text { Much Less Safe } & 10 & 7 & 11 & 8 & 11 & 13 \\ \text { Unsafe } & 12 & 15 & 11 & 8 & 11 & 13 \\ \text { No nnswer } & 3 & 7 & 2 & 3 & 11 & 0\end{array}$

ARE SUCH MURDERERS CRAZY?

$\begin{array}{lrrrrrr}\text { Yes } & 27 & 19 & 31 & 18 & 32 & 37 \\ \text { No } & 39 & 41 & 39 & 38 & 37 & 43 \\ \text { Unsure } & 31 & 33 & 31 & 45 & 21 & 20 \\ \text { No Answer } & 2 & 7 & 0 & 0 & 11 & 0\end{array}$


APPENDIX G CONTINUED

ARE SUCH MURDERS: $\underline{I} \quad \underline{F} \quad \underline{M} \quad \underline{1} \quad \underline{2} \quad \underline{3}$

$\begin{array}{lllllll}\text { Senseless } & 60 & 52 & 63 & 55 & 58 & 67\end{array}$

$\begin{array}{lrrrrrr}\text { Understandable } & 35 & 41 & 32 & 40 & 26 & 33 \\ \text { No Answer } & 6 & 7 & 5 & 5 & 16 & 0\end{array}$

IS IT MASS MURDER IF CIVILIANS ARE KILLED DURING WAR?

$\begin{array}{lrrrrrr}\text { Yes } & 78 & 52 & 89 & 75 & 74 & 83 \\ \text { No } & 9 & 22 & 3 & 13 & 0 & 10 \\ \text { No Answer } & 1 & 4 & 0 & 0 & 5 & 0 \\ \text { Sometimes } & 12 & 22 & 8 & 13 & 21 & 7\end{array}$

HOW DOES THIS AFFECT YOUR FEELINGS OF SAFETY?

$\begin{array}{lrrrrrr}\text { No Affect } & 18 & 37 & 10 & 13 & 32 & 17 \\ \text { A Little Less Safe } & 37 & 30 & 40 & 48 & 26 & 30 \\ \text { Much Less Safe } & 28 & 15 & 34 & 28 & 26 & 30 \\ \text { Unsafe } & 16 & 15 & 16 & 13 & 11 & 23 \\ \text { No Answer } & 1 & 4 & 0 & 0 & 5 & 0\end{array}$

ARE SUCH MURDERERS CRAZY?

$\begin{array}{lrrrrrr}\text { Yes } & 42 & 44 & 40 & 33 & 42 & 53 \\ \text { No } & 27 & 26 & 27 & 28 & 21 & 30 \\ \text { Unsure } & 29 & 22 & 32 & 40 & 26 & 17 \\ \text { No Answer } & 2 & 7 & 0 & 0 & 11 & 0\end{array}$

ARE SUCH MURDERS:

$\begin{array}{lrrrrrr}\text { Senseless } & 83 & 85 & 82 & 83 & 89 & 80 \\ \text { Understandable } & 13 & 11 & 15 & 13 & 5 & 20 \\ \text { No Answer } & 3 & 4 & 3 & 5 & 5 & 0\end{array}$

IS IT MASS MURDER IF MILITARY PERSONNEL ARE KILLED NOT AT WAR?

$\begin{array}{lrrrrrr}\text { Yes } & 88 & 81 & 90 & 93 & 84 & 83 \\ \text { No } & 1 & 0 & 2 & 0 & 5 & 0 \\ \text { No Answer } & 2 & 7 & 0 & 3 & 5 & 0 \\ \text { Sometimes } & 9 & 11 & 8 & 5 & 5 & 17\end{array}$

HOW DOES THIS AFFECT YOUR FEELINGS OF SAFETY?

$\begin{array}{lrrrrrr}\text { No Affect } & 28 & 56 & 16 & 33 & 32 & 20 \\ \text { A Little Less Safe } & 34 & 4 & 47 & 33 & 42 & 30 \\ \text { Much Less Safe } & 26 & 22 & 27 & 28 & 16 & 30 \\ \text { Unsafe } & 11 & 15 & 10 & 8 & 5 & 20 \\ \text { No Answer } & 1 & 4 & 0 & 0 & 5 & 0\end{array}$

ARE SUCH MURDERERS CRAZY?

$\begin{array}{lrrrrrr}\text { Yes } & 63 & 63 & 63 & 65 & 53 & 67 \\ \text { No } & 11 & 11 & 13 & 7 & 21 & 17 \\ \text { Unsure } & 22 & 19 & 24 & 30 & 16 & 17 \\ \text { No Answer } & 2 & 7 & 0 & 0 & 11 & 0\end{array}$

ARE SUCH MURDERS:

Senseless

Understandable

No Answer

$\begin{array}{rrrrrr}90 & 85 & 92 & 93 & 84 & 90 \\ 7 & 7 & 6 & 3 & 11 & 10 \\ 3 & 7 & 2 & 5 & 5 & 0\end{array}$


APPENDIX G CONTINUED

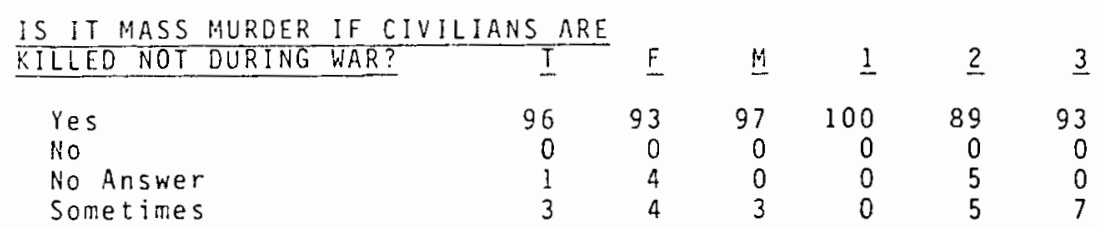

HOW DOES THIS AFFECT YOUR FEELINGS OF SAFETY?

$\begin{array}{lrrrrrr}\text { No Affect } & 13 & 33 & 5 & 10 & 26 & 10 \\ \text { A Little Less Safe } & 37 & 26 & 42 & 35 & 37 & 40 \\ \text { Viuch Less Safe } & 24 & 15 & 27 & 25 & 16 & 27 \\ \text { Unsafe } & 25 & 22 & 26 & 30 & 16 & 23 \\ \text { No Answer } & 1 & 4 & 0 & 0 & 5 & 0\end{array}$

ARE SUCH MURDERERS CRAZY?

$\begin{array}{lrrrrrr}\text { Yes } & 66 & 63 & 68 & 75 & 58 & 60 \\ \text { No } & 15 & 7 & 18 & 3 & 16 & 30 \\ \text { Unsure } & 17 & 22 & 15 & 23 & 16 & 10 \\ \text { No Answer } & 2 & 7 & 0 & 0 & 11 & 0\end{array}$

No Answer

ARE SUCH MURDERS:

Senseless

Understandable

No Answer

$\begin{array}{rrrrrr}92 & 93 & 92 & 98 & 89 & 87 \\ 6 & 4 & 6 & 3 & 5 & 10 \\ 2 & 4 & 2 & 0 & 5 & 3\end{array}$

IS IT MASS MURDER IF THE KILLERS ARE ORGANIZED CRIMINALS?

$\begin{array}{lrrrrrr}\text { Yes } & 98 & 96 & 98 & 98 & 95 & 100 \\ \text { io } & 0 & 0 & 0 & 0 & 0 & 0 \\ \text { No Answer } & 1 & 4 & 0 & 0 & 5 & 0 \\ \text { Sometimes } & 1 & 0 & 2 & 3 & 0 & 0\end{array}$

HOW DOES THIS AFFECT YOUR FEELINGS OF SAFETY?

$\begin{array}{lrrrrrr}\text { No Affect } & 21 & 48 & 10 & 20 & 26 & 20 \\ \text { A Little Less Safe } & 40 & 15 & 52 & 43 & 47 & 33 \\ \text { Much Less Safe } & 18 & 11 & 21 & 20 & 11 & 20 \\ \text { Unsafe } & 19 & 22 & 18 & 18 & 11 & 27 \\ \text { No Answer } & 1 & 4 & 0 & 0 & 5 & 0\end{array}$

ARE SUCH MURDERERS CRAZY?

$\begin{array}{lrrrrrr}\text { Yes } & 51 & 52 & 50 & 53 & 47 & 50 \\ \text { No } & 21 & 15 & 24 & 13 & 21 & 33 \\ \text { Unsure } & 26 & 26 & 26 & 35 & 21 & 17 \\ \text { No Answer } & 2 & 7 & 0 & 0 & 11 & 0\end{array}$

ARE SUCH MURDERS:

$\begin{array}{lrrrrrr}\text { Senseless } & 83 & 81 & 84 & 88 & 79 & 80 \\ \text { Understandable } & 11 & 7 & 13 & 8 & 11 & 17 \\ \text { No Answer } & 6 & 11 & 3 & 5 & 11 & 3\end{array}$

IS IT MASS MURDER IF IT IS THE RESULT OF TERRORIST ACTIVITY?

$\begin{array}{lrrrrrr}\text { Yes } & 96 & 89 & 98 & 100 & 79 & 100 \\ \text { No } & 1 & 4 & 0 & 0 & 5 & 0 \\ \text { No Answer } & 1 & 4 & 0 & 0 & 5 & 0 \\ \text { Sometimes } & 2 & 4 & 2 & 0 & 11 & 0\end{array}$


APPENDIX G CONTINUED

HOW DOES THIS AFFECT YOUR

\begin{tabular}{lrrrrrr} 
FEELINGS OF SAFETY? & T & F & $\underline{M}$ & $\underline{1}$ & $\underline{2}$ & $\underline{3}$ \\
\hline No Affect & 19 & 37 & 11 & 13 & 32 & 20 \\
A Little Less Safe & 42 & 26 & 48 & 53 & 42 & 27 \\
Much Less Safe & 18 & 11 & 21 & 15 & 16 & 23 \\
Unsafe & 20 & 22 & 19 & 20 & 5 & 30 \\
No Answer & 1 & 4 & 0 & 0 & 5 & 0
\end{tabular}

ARE SUCH MURDERERS CRAZY?

$\begin{array}{lrrrrrr}\text { Yes } & 55 & 59 & 53 & 65 & 42 & 50 \\ \text { No } & 18 & 7 & 23 & 10 & 16 & 30 \\ \text { Unsure } & 25 & 26 & 24 & 25 & 32 & 20 \\ \text { No Answer } & 2 & 7 & 0 & 0 & 11 & 0\end{array}$

ARE SUCH MURDERS:

$\begin{array}{lrrrrrr}\text { Senseless } & 82 & 81 & 82 & 90 & 74 & 77 \\ \text { Understandable } & 11 & 11 & 11 & 8 & 5 & 20 \\ \text { No Answer } & 7 & 7 & 6 & 3 & 21 & 3\end{array}$

IS IT MASS MURDER IF IT IS THE RESULT OF A GANG CONFLICT?

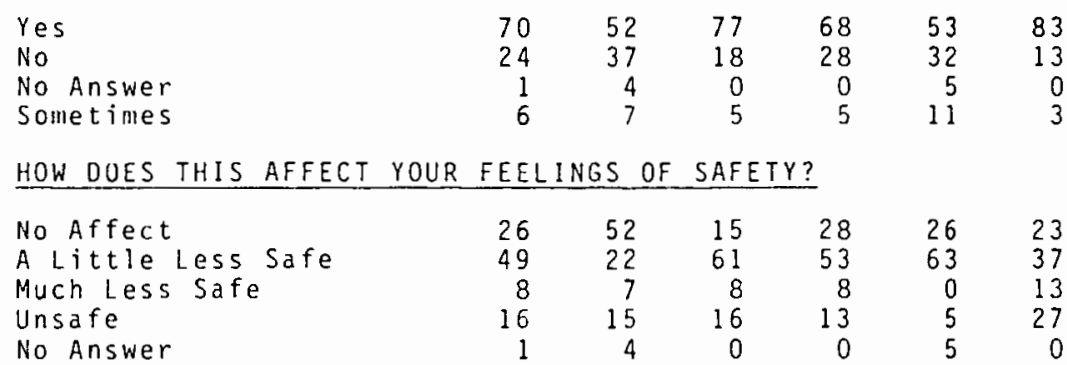

ARE SUCH MURDERERS CRAZY?

$\begin{array}{lrrrrrr}\text { Yes } & 39 & 30 & 44 & 38 & 32 & 47 \\ \text { No } & 26 & 26 & 26 & 20 & 26 & 33 \\ \text { Unsure } & 33 & 37 & 31 & 43 & 32 & 20 \\ \text { No Answer } & 2 & 7 & 0 & 0 & 11 & 0\end{array}$

ARE SUCH MURDERS:

$\begin{array}{lrrrrrr}\text { Senseless } & 88 & 93 & 85 & 95 & 89 & 77 \\ \text { Understandabie } & 10 & 4 & 13 & 5 & 5 & 20 \\ \text { No Answer } & 2 & 4 & 2 & 0 & 5 & 3\end{array}$

IS IT MASS MURDER IF THE KILLER IS A HIRED KILLER?

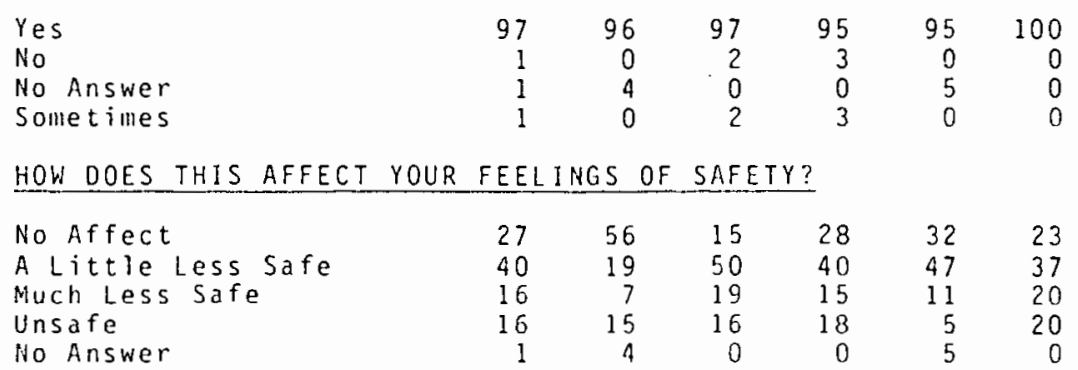


APPENDIX G CONTINUED

$\begin{array}{lrrrrrr}\text { ARE SUCH MURDERERS CRAZY? } & I & \underline{F} & \underline{M} & \underline{1} & \underline{2} & \underline{3} \\ \text { Yes } & 54 & 59 & 52 & 58 & 58 & 47 \\ \text { No } & 24 & 15 & 27 & 18 & 5 & 43 \\ \text { Unsure } & 20 & 19 & 21 & 15 & 26 & 10 \\ \text { No Answer } & 2 & 7 & 0 & 0 & 11 & 0\end{array}$

ARE SUCH MUROERS:

$\begin{array}{lrrrrrr}\text { Senseless } & 82 & 85 & 81 & 85 & 84 & 77 \\ \text { Understandabie } & 16 & 7 & 19 & 15 & 5 & 23 \\ \text { No Answer } & 2 & 7 & 0 & 0 & 11 & 0\end{array}$


LEGEND :
T) Total Percentage
F) Femaie Percentage
1) Under 24 Years of Age
2) $24-29$ Years of Age
M) Male Percentage
3) 30 Years of Age and Over

\begin{tabular}{|c|c|c|c|c|c|c|}
\hline ITEM & I & $\underline{F}$ & $\underline{4}$ & 1 & $\underline{2}$ & $\underline{3}$ \\
\hline Johnny Carson & 96 & 94 & 100 & 100 & 100 & 86 \\
\hline Billie Jean King & 96 & 94 & 100 & 96 & 100 & 93 \\
\hline Watergate & 94 & 94 & 93 & 92 & 100 & 100 \\
\hline Mel Brooks & 91 & 88 & 100 & 88 & 100 & 93 \\
\hline Vidal Sassoon & 91 & 91 & 93 & 96 & 88 & 93 \\
\hline Arnold Palmer & 89 & 85 & 100 & 84 & 100 & 93 \\
\hline Bruce Lee & 89 & 85 & 100 & 92 & 88 & 86 \\
\hline Anwar Sadat & 87 & 82 & 100 & 84 & 88 & 93 \\
\hline Charles Manson* & 87 & 85 & 93 & 76 & 100 & 93 \\
\hline Janis Joplin & 86 & 85 & 93 & 72 & 100 & 93 \\
\hline Henry Mancini & 77 & 73 & 86 & 64 & 100 & 86 \\
\hline Hubert Humphrey & 72 & 67 & 86 & 56 & 88 & 93 \\
\hline Neil Simon & 70 & 70 & 71 & 72 & 75 & 71 \\
\hline Sharon Tate* & 62 & 55 & 71 & 44 & 75 & 86 \\
\hline Roy Orbison & 55 & 45 & 79 & 48 & 50 & 79 \\
\hline Cyrus Vance & 55 & 52 & 64 & 44 & 63 & 71 \\
\hline Golda Meir & 53 & 52 & 57 & 36 & 88 & 71 \\
\hline William Westmoreland & 51 & 42 & 71 & 32 & 63 & 79 \\
\hline Andy Warhol & 49 & 39 & 71 & 32 & 63 & 79 \\
\hline John Dean & 49 & 39 & 71 & 20 & 75 & 86 \\
\hline Bill Blass & 49 & 52 & 43 & 44 & 25 & 71 \\
\hline Anne klein & 45 & 55 & 21 & 60 & 25 & 29 \\
\hline Jacquelin Susann & 43 & 39 & 50 & 20 & 50 & 79 \\
\hline Elvin Bishop & 40 & 36 & 50 & 52 & 50 & 14 \\
\hline Erica Jong & 40 & 36 & 50 & 24 & 50 & 64 \\
\hline Buzz Aldrin & 40 & 27 & 71 & 16 & 63 & 71 \\
\hline Earl Warren & 38 & 27 & 64 & 8 & 63 & 79 \\
\hline Jack Ruby & 38 & 30 & 57 & 16 & 38 & 79 \\
\hline My Lãi & 36 & 24 & 64 & 8 & 63 & 71 \\
\hline
\end{tabular}


APPENDIX H CONTINUED

\begin{tabular}{|c|c|c|c|c|c|c|}
\hline ITEM & $\underline{I}$ & $\underline{F}$ & $\underline{M}$ & $\underline{1}$ & $\underline{2}$ & $\underline{3}$ \\
\hline Morris Udhal & 36 & 21 & 64 & 8 & 50 & 71 \\
\hline rrank Church & 32 & 18 & 64 & 16 & 63 & 43 \\
\hline Draft Lottery & 32 & 33 & 29 & 16 & 38 & 57 \\
\hline Norman Vincent Pee? & 32 & 23 & 47 & 16 & 25 & 64 \\
\hline Robert Macnamara & 30 & 18 & 57 & 12 & 13 & 71 \\
\hline Timothy Leary & 30 & 21 & 50 & 8 & 25 & 71 \\
\hline Leslie Gore & 28 & 29 & 36 & 12 & 25 & 64 \\
\hline Klaus Barbic & 26 & 18 & 43 & 12 & 50 & 36 \\
\hline Stanley Kubrick & 23 & 12 & 50 & 4 & 25 & 57 \\
\hline Marshal Tito & 23 & 15 & 43 & 0 & 13 & 71 \\
\hline John Lindsey & 21 & 12 & 43 & 0 & 0 & 71 \\
\hline Judith Crist & 21 & 12 & 43 & 4 & 25 & 50 \\
\hline Rosemary Woods & 19 & 12 & 36 & 0 & 38 & 43 \\
\hline Rosemary Labianca* & 17 & 18 & 14 & 16 & 13 & 21 \\
\hline Leno Labianca* & 15 & 18 & 7 & 12 & 13 & 21 \\
\hline Ry Cooder & 15 & 6 & 36 & 8 & 25 & 21 \\
\hline Joesph Yablonski & 15 & 12 & 21 & 0 & 25 & 36 \\
\hline Charlie Tickner & 13 & 12 & 14 & 24 & 0 & 0 \\
\hline Yippies & 13 & 9 & 21 & 0 & 50 & 14 \\
\hline Clare Luce Booth & 13 & 12 & 14 & 4 & 13 & 29 \\
\hline Lorna Luft & 11 & 12 & 7 & 4 & 13 & 21 \\
\hline Peter Cook & 6 & 0 & 21 & 4 & 13 & 7 \\
\hline Les?ie Van Houten* & 6 & 6 & 7 & 8 & 0 & 7 \\
\hline Susan Atkins* & 6 & 6 & 7 & 4 & 0 & 14 \\
\hline Charles Watson* & 6 & 6 & 7 & 8 & 0 & 7 \\
\hline Abigail Folger* & 6 & 6 & 7 & 4 & 0 & 14 \\
\hline Sal Mineo* & 4 & 3 & 7 & 0 & 0 & 14 \\
\hline Zebra* & 4 & 0 & 14 & 0 & 0 & 14 \\
\hline Willard Wirtz & 4 & 0 & 14 & 0 & 0 & 14 \\
\hline Jay Sebring* & 4 & 6 & 0 & 4 & 0 & 7 \\
\hline Patricia Krenwinkle* & 4 & 6 & 0 & 4 & 0 & 7 \\
\hline Voytek Frykowski* & 4 & 6 & 0 & 8 & 0 & 0 \\
\hline Peter Schaffer & 2 & 3 & 0 & 4 & 0 & 0 \\
\hline Steven Parent* & 2 & 3 & 0 & 4 & 0 & 0 \\
\hline Marlene 0live* & 0 & 0 & 0 & 0 & 0 & 0 \\
\hline Elmer Wayne Henley Jr.* & 0 & 0 & 0 & 0 & 0 & 0 \\
\hline Sandra Beain* & 0 & 0 & 0 & 0 & 0 & 0 \\
\hline Dean Corl1* & 0 & 0 & 0 & 0 & 0 & 0 \\
\hline Billy Isaacs* & 0 & 0 & 0 & 0 & 0 & 0 \\
\hline Carl Isaacs* & 0 & 0 & 0 & 0 & 0 & 0 \\
\hline J. C. Sinions & 0 & 0 & 0 & 0 & 0 & 0 \\
\hline Manuel Moore* & 0 & 0 & 0 & 0 & 0 & 0 \\
\hline Dr. Ohta* & 0 & 0 & 0 & 0 & 0 & 0 \\
\hline
\end{tabular}


APPENDIX H CUNTINUED

\begin{tabular}{|c|c|c|c|c|c|}
\hline ITEM & $\underline{I}$ & $\underline{F}$ & $M$ & 1 & $\underline{2}$ \\
\hline John Linley Frazier* & 0 & 0 & 0 & 0 & 0 \\
\hline Gertrude Baniszewski* & 0 & 0 & 0 & 0 & 0 \\
\hline George Dungee* & 0 & 0 & 0 & 0 & 0 \\
\hline Wayne Coleman* & 0 & 0 & 0 & 0 & 0 \\
\hline Frederick Cowan* & 0 & 0 & 0 & 0 & 0 \\
\hline Robert Benjamin Smith* & 0 & 0 & 0 & 0 & 0 \\
\hline Jesse Cooke* & 0 & 0 & 0 & 0 & 0 \\
\hline Larry Green* & 0 & 0 & 0 & 0 & 0 \\
\hline Sylvia Likens* & 0 & 0 & 0 & 0 & 0 \\
\hline David Owen Brooks* & 0 & 0 & 0 & 0 & 0 \\
\hline Lionel Ray Williams* & 0 & 0 & 0 & 0 & 0 \\
\hline Charles David Riley* & 0 & 0 & 0 & 0 & 0 \\
\hline William Steelman* & 0 & 0 & 0 & 0 & 0 \\
\hline Norma Jean Armistead* & 0 & 0 & 0 & 0 & 0 \\
\hline Anthony Harris* & 0 & 0 & 0 & 0 & 0 \\
\hline Pete Athens & 0 & 0 & 0 & 0 & 0 \\
\hline Charlie Scott & 0 & 0 & 0 & 0 & 0 \\
\hline Carol Parker & 0 & 0 & 0 & 0 & 0 \\
\hline Clive Barnes & 0 & 0 & 0 & 0 & 0 \\
\hline Mimi Garrard & 0 & 0 & 0 & 0 & 0 \\
\hline Barbara Ann Cockran & 0 & 0 & 0 & 0 & 0 \\
\hline Adele Erb Sullivan & 0 & 0 & 0 & 0 & 0 \\
\hline Donald C. Alexander & 0 & 0 & 0 & 0 & 0 \\
\hline Sonny Terry & 0 & 0 & 0 & 0 & 0 \\
\hline David Sackson & 0 & 0 & 0 & 0 & 0 \\
\hline Carol Vadnais & 0 & 0 & 0 & 0 & 0 \\
\hline Roosevelt Boule & 0 & 0 & 0 & 0 & 0 \\
\hline Walter Kapryn & 0 & 0 & 0 & 0 & 0 \\
\hline Gloria Thomas & 0 & 0 & 0 & 0 & 0 \\
\hline Richard $A$. Roth & 0 & 0 & 0 & 0 & 0 \\
\hline
\end{tabular}


RESULTS OF THE CONTENT ANALYSIS:

PERCENTAGE OF ARTICLES CONTAINING SELECT ITEMS

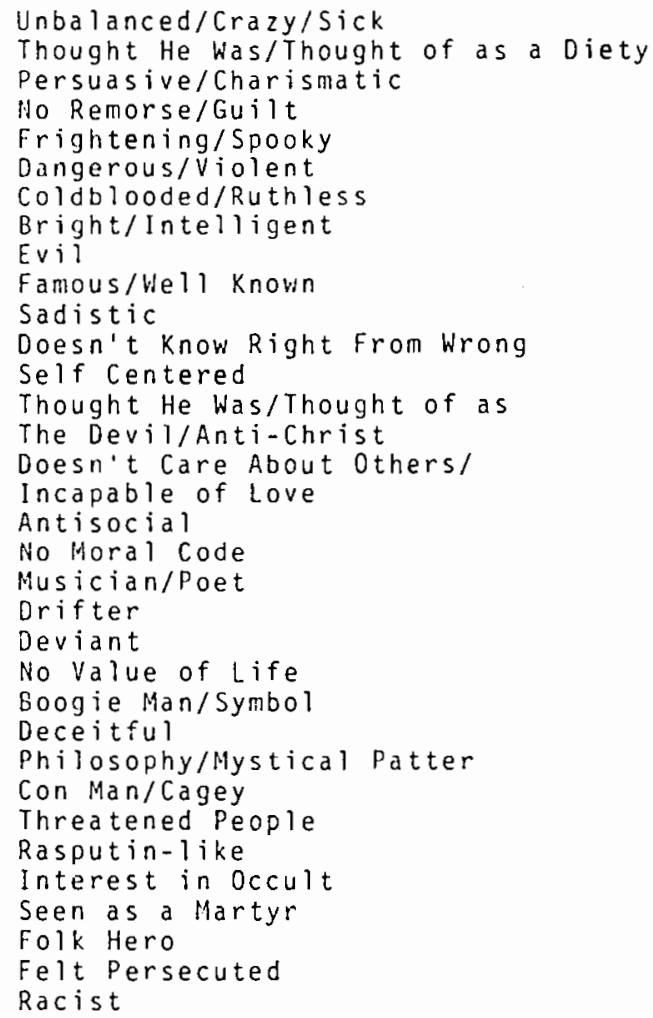

\section{MANSON'S PHYSICAL ATTRIBUTES}

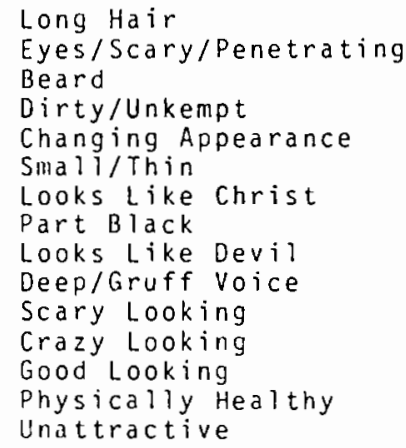


APPENDIX 1 CONTINUED

UUDICIAL MATTERS

NEW YORK TIMES MAGAZINES

In Prison

Came Up For Parole

Convicted of Murder

Serving Life

Afraid $\mathrm{He}$ "li Be Paroled

Should Have Been Executed

Followers Convicted

Will Never Be Released

Manson's Criminal History

Model Prisoner

Told Them llot to Let Him out in $60^{\prime} \mathrm{s}$

Protected From other inmates

Refused Parole

Would Be Killed if Let out

I Would Feel Let Down By

The System if He Was let out

Made Threats at Trial

Judge's h'atch Stopped

Women Brindly obedient at Tria!

out on Parole

Might Come Here

Unruly at Trial

Susan Atkins Broke the case

Death Penalty

Nixon Said They Were Guilty During Trial 4

$\begin{array}{rr}0 & 13 \\ 1 & 7\end{array}$

22

12
2

0

25

28

1

0

0

0

10

0

23

0

27

18

12

VICTIMS

Sharon Tate

Pregnant Victim

Others killed Besides Tate

Labianca/0ther Couple

Famous Victim/Actress

Women/Beautiful Women

Other Murders

Hairdresser (Jay Sebring)

Coffee Heiress (Abigail Folger)

Roman Polanski's Wife

Killed Cnildren

Cut Up Girls \& Put Them in His Freezer

Innocent Victims

Voytek Frykowski

Steven Parent

Gary Hinman

$81 \quad 84$

625

50

$\begin{array}{ll}43 & 53 \\ 56 & 45\end{array}$

0

22

22

19

28

0

1

13

12

\section{NATURE OF CRIHE/EVIDENCE}

Brutal/B loody/Grotesque

California

Writing in Blood

Used Knives/Stabbed

Bizarre

Stabbed/Cut out Baby

Rope/Hung Someone

Victims Sexually Abused

Ritualistic

Used a Fork to Stab

Mutilation

Torture

Robbery Involved

Shot victims

Random Choice

Took Over House For Hours

Used Baby's Blood on Wall

Signs of a Struggle

Sign of the Times

Tate Mansion 
APPENDIX I CONTINUED

Manson is a Murderer/Mass Murderer

Followers Helped/Did it

Manson Caused/Ordered/Planned Murders

Don't know if Manson Murdered

Manson Didn't Murder

Manson Denied Killing

People Said He Murdered

Lina Kasabian Didn't Kill

\section{FOLLOWERS}

Had Followers/A Group

They Hould Do Anything For Him

Primarily women

Lynette 'Squeaky' Fromme

'Family'

Still Has Loyal Followers

Wollien Shaved Their Heads

Followers Worshipped Himidisciples

Weak/Vulnerable/Gullible

Followers Were Mentally unbalanced/Sick

Manson Recruited Followers

Leslie Van Houten

Young Followers

Children in Group

Followers Feared Manson

Long Hair

Dirty/Unkempt

Susan Atkins

Robots/Slaves/Zombies

Charles (Tex) Watson

Patricia Krenwinkle

Linda Kasabian

Girls Were Good Looking

Nudity

Sandra Good

Formerly Good/Corrupted by Manson

Dropouts/Misfits

Robert Beausolei]

From Unhappy Homes

Violent/Dangerous

Women Were Subservient

From Broken Homes

vacuous/spaced out

Inappropriate Affect

Girls were witch-Like

Loved Manson

Bad to Begin with

Colablooded/Ruthless

$\begin{array}{rr}60 & 92 \\ 3 & 23 \\ 39 & 67 \\ 2 & 45 \\ 49 & 77 \\ 6 & 40 \\ 1 & 5 \\ 6 & 25 \\ 4 & 25 \\ 6 & 25 \\ 1 & 25 \\ 44 & 35 \\ 26 & 38 \\ 2 & 12 \\ 1 & 7 \\ 2 & 7 \\ 1 & 10 \\ 45 & 53 \\ 5 & 25 \\ 23 & 30 \\ 42 & 40 \\ 24 & 40 \\ 1 & 10 \\ 1 & 12 \\ 2 & 33 \\ 1 & 11 \\ 4 & 27 \\ 5 & 10 \\ 1 & 18 \\ 1 & 15 \\ 2 & 23 \\ 1 & 12 \\ 1 & 22 \\ 2 & 20 \\ 1 & 12 \\ 3 & 15 \\ 0 & 10 \\ 4 & 13 \\ & \\ 1 & 25\end{array}$

\section{LIFESTYLE}

Drugs

Unusual/Abusive/Free Sex

Satanic/0ccult

Cult/Pseudo Religious

Communal Living

Lived in Desert

Lived on Ranch/Spahn

Hippies

Dune Buggies/Car The ft

Ate From Garbage

Sang Together

Rainshackle Surrounds

Armed Camp/Militaristic

$V$ iolence

$\begin{array}{rr}17 & 47 \\ 7 & 45 \\ 1 & 15 \\ 14 & 35 \\ 5 & 32 \\ 9 & 32 \\ 17 & 27 \\ 41 & 27 \\ 4 & 23 \\ 2 & 15 \\ 2 & 10 \\ 3 & 18 \\ 4 & 22 \\ 1 & 20\end{array}$


APPENDIX I CONTINUED

\section{LIFESTYLE}

NEW YORK TIMES MAGAZINES

Motorcycle Gangs

Nomadic

Haight-Asbury

Planning For Armageddon

General Theft

Indolent/Lazy

MANSOI'S RELATIONSHIP TO FOLLOWERS

$\begin{array}{lrr}\text { Cult Leader } & 13 & 20 \\ \text { Brainwashed/Controlled } & 6 & 23 \\ \text { Leader } & 56 & 38 \\ \text { Hypnotic Control } & 5 & 32 \\ \text { Abnormal Hold } & 4 & 27 \\ \text { Used Drugs to Control } & 1 & 13 \\ \text { Used People For Own Gain } & 0 & 3 \\ \text { Had Others Do Dirty Work } & 0 & 3 \\ \text { Gave Them Something to Believe in } & 1 & 25 \\ \text { Guru Hurt His Followers } & 4 & 5 \\ \text { Hurt } & 1 & 17 \\ \text { Used Women to Get Favors \& Male Followers } & 2 & 18 \\ \text { Used Sex to Control } & 1 & 18\end{array}$

REASONS/INFLUENCES

Start a Race War

Anti-Establishment/Anti-Society

Beatles 'Songs

No Reason/Motive

Felt They Were Right/Victims Deserved it

Probably Abused Child

To Take Over

Poor Parenting/Bad Childhood

Stranger In A Stange Land

Contents of Roman's filins

Victins Into Drugs

victims Into occult

victims Ran with a Fast Crowd

Victims into wierd Sex

Revenge Against Terry Melcher

People Were Destroying the Earth

Unusual Ideas About Death

Counter Culture

Manson's interpretation of the Bible

$\begin{array}{ll}4 & 12 \\ 8 & 20 \\ 4 & 18 \\ 3 & 18 \\ 3 & 22 \\ 1 & 12\end{array}$

12

8

12

20

3

32

27

3

8

3

5

7

18

18

MEDIA RELATED ISSUES

38

$\frac{\text { Helter Skelter }}{\text { A Lot of Coverage }}$

Manson Interviewed by Tom Snyder

Manson Loved Hedia At tention

Speculation/Sensationalism

The Family

Persecuted By Press

Several Books

Tria? Could Be Affected By Press

MISCELLANEOUS

Evokes Rage/Hate

Born Again Christians

Perpetuates Hate in Guise of Love

Owns Land in California

Reminds lie of $\mathrm{Hitler}$

Poor White Mother

17

20

0

3

12

7
3

1

10 


\section{APPENDIX I CONTINUED}

MISCELLANEOUS

Creepy Crawly Missions

Not a Deprived Background

Was in $\mathrm{His} 20^{\prime} \mathrm{s}$

Truman Capote Wrote Helter Skelter

Murders Caused Fear

'Family' Associated With Dennis Wilson

of The Beach Boys

Manson's Record Album

The End of an Era
NEW YORK TIMES MAGAZINES

$\begin{array}{lr}1 & 7 \\ 0 & 0 \\ 0 & 0 \\ 0 & 0 \\ 1 & 10 \\ 2 & 12 \\ 1 & 12 \\ 1 & 10\end{array}$

